A systematic review of observational methods used to quantify personal protective behaviours among members of the public during the COVID-19 pandemic, and the concordance between observational and self-report measures in infectious disease health protection

Rachel Davies ${ }^{1}$, Fiona Mowbray ${ }^{1}$, Alex F Martin ${ }^{1}$, Louise E Smith ${ }^{1}$, G James Rubin ${ }^{1}$

${ }^{1}$ National Institute of Health Research Health Protection Research Unit in Emergency

Preparedness and Response at King's College London, in partnership with the UK Health Security Agency.

Corresponding author: Rachel Davies, King's College London, Rachel.2.davies@kcl.ac.uk 
medRxiv preprint doi: https://doi.org/10.1101/2021.12.22.21268226; this version posted December 23, 2021. The copyright holder for this preprint (which was not certified by peer review) is the author/funder, who has granted medRxiv a license to display the preprint in perpetuity. It is made available under a CC-BY 4.0 International license .

\section{Contribution of authors:}

RD: created the search strategy, carried out database searches, identified abstracts for inclusion, extracted data, interpreted the results and wrote and revised the manuscript

FM: carried out database searches, identified abstracts for inclusion, extracted data and revised the manuscript

LS: advised on the search strategy and revised the manuscript

AFM: identified abstracts for inclusion, extracted data and revised the manuscript

GJR: conceived and designed the study and aims, advised on results and revised the manuscript 
medRxiv preprint doi: https://doi.org/10.1101/2021.12.22.21268226; this version posted December 23, 2021. The copyright holder for this preprint (which was not certified by peer review) is the author/funder, who has granted medRxiv a license to display the preprint in perpetuity.

It is made available under a CC-BY 4.0 International license .

\begin{abstract}
Objectives: To assess the quantity and quality of studies using an observational measure of behaviour during the COVID-19 pandemic, and to narratively describe the association between selfreport and observational data for behaviours relevant to controlling an infectious disease outbreak.
\end{abstract}

Design: Systematic review and narrative synthesis of observational studies.

Data sources: We searched Medline, Embase, PsychInfo, Publons, Scopus and the Public Health England behavioural science LitRep database from inception to $17^{\text {th }}$ September 2021 for relevant studies.

Study selection: We included studies which collected observational data of at least one of three health protective behaviours (hand hygiene, face covering use and maintaining physical distance from others ('social distancing')) during the COVID-19 pandemic. Studies where observational data were compared to self-report data in relation to any infectious disease were also included.

Data extraction and synthesis: We evaluated the quality of studies using the NIH quality assessment scale for observational studies, extracted data on sample size, setting and adherence to health protective behaviours, and synthesized results narratively.

Results: Of 27,279 published papers on COVID-19 relevant health protective behaviours that included one or more terms relating to hand hygiene, face covering and social distancing, we identified 48 studies that included an objective observational measure. Of these, 35 assessed face covering use, 17 assessed hand hygiene behaviour and seven assessed physical distancing. The general quality of these studies was good. When expanding the search to all infectious diseases, we included 21 studies that compared observational versus self-report data. These almost exclusively studied hand hygiene. The difference in outcomes was striking, with self-report over-estimating observed adherence by up to a factor of five in some settings. In only four papers did self-report match observational data in any domains. 
medRxiv preprint doi: https://doi.org/10.1101/2021.12.22.21268226; this version posted December 23, 2021. The copyright holder for this preprint (which was not certified by peer review) is the author/funder, who has granted medRxiv a license to display the preprint in perpetuity. It is made available under a CC-BY 4.0 International license .

Conclusions: Despite their importance in controlling the pandemic, we found remarkably few studies assessing protective behaviours by observation, rather than self-report, though these studies tended to be of reasonably good quality. Observed adherence tends to be substantially lower than estimates obtained via self-report. Accurate assessment of levels of personal protective behaviour, and evaluation of interventions to increase this, would benefit from the use of observational methods. 


\section{Background}

Throughout the COVID-19 pandemic, members of the public have been urged to engage in a set of behaviours intended to reduce transmission of the SARS-CoV- 2 virus. These have included recommendations to practice frequent hand hygiene, avoid close contact with other people ('social distancing') and to wear a face covering to prevent spread through respiratory droplets. ${ }^{1,2}$ Although these interventions have been shown to be effective in reducing the transmission of SARS-CoV- $2{ }^{3}$ none of the interventions will work if people do not adhere to them or understand the messaging on when they should adhere. ${ }^{4}$

To date, public engagement with recommended behaviours has primarily been monitored by behavioural scientists, public health agencies and national governments though the use of selfreport questionnaires. Using self-report methods to collect data has many benefits. Self-reported data can be quick, easy and relatively inexpensive to obtain from large numbers of participants. The association between self-reported behaviour and other self-reported variables is also relatively straightforward to examine. For many outcomes, self-report can be a good proxy measure for actual behaviour ${ }^{5}$. For example, self-report can be a useful way to assess whether someone has been vaccinated or not ${ }^{6}$. For other behaviours, self-report may be less valid ${ }^{7}$. This may be particularly true for frequently performed behaviours that are difficult to remember (e.g. frequency of handwashing in the past 24 hours) or that would be socially undesirable to admit (e.g. breaking legally enforceable rules around self-isolation $)^{8,9,10}$.

In the context of COVID-19, regularly collected measures of behaviour that do not rely on self-report are rare. Notable exceptions include: mobility data based on mobile phone locations ${ }^{11}$; footfall data in city centres ${ }^{12}$; and official statistics on vaccine uptake based on electronic records ${ }^{13}$. Most of these examples relate to where people are located or whether they engage with health services. 
medRxiv preprint doi: https://doi.org/10.1101/2021.12.22.21268226; this version posted December 23, 2021. The copyright holder for this preprint (which was not certified by peer review) is the author/funder, who has granted medRxiv a license to display the preprint in perpetuity. It is made available under a CC-BY 4.0 International license .

There are fewer regularly collected data based on direct observation quantifying whether and how people engage with COVID-19 protective behaviours. To assist public health agencies in considering whether to collect more observational data, we conducted a systematic review of the use of observational measures of COVID-19 relevant behaviours. We focussed on studies that directly observed the performance of protective behaviours, excluding measures of mobility or location. Our aims were to assess: 1) the quantity of observational studies conducted during COVID-19; 2) the quality of these studies; and 3) the association between self-report and observational data. While we only included COVID-19 related studies for aims one and two, given a lack of data found during screening, we expanded our inclusion criteria for aim three and included studies relating to any infectious disease outbreak. 


\section{Methods}

Protocol and registration

This review follows the PRISMA framework and is registered with PROSPERO registration number CRD42021261360. The study protocol is available from: https://www.crd.york.ac.uk/prospero/display record.php?ID=CRD42021261360

\section{Search strategies}

For aims one and two, we searched the following electronic databases from inception to $17^{\text {th }}$ September 2021: Medline, Embase, Psyclnfo, Publons, Scopus, and the Public Health England (PHE) behavioural science COVID-19 Literature Repository database (BSIU LitRep Database. Google Docs. Available

from:https://docs.google.com/spreadsheets/d/1qfR4NgnD5hTAS8KriPaXYhLu1s7fpZJDq8EIXQY0ZEs/edi t\#gid=369408275 (Accessed November 2021)). Databases were searched for articles containing MeSH terms or keywords relating to COVID-19 (e.g. "SARS-CoV-2", "novel coronavirus"), hand hygiene, physical distancing, or face coverings (e.g. "hand washing", "face mask", "physical distancing") and an observational method (e.g. "observational study", "videorecording"). Full details of our search strategies are available in Supplementary material.

For aim three, we searched Medline, Embase and Psyclnfo from inception to $17^{\text {th }}$ September 2021.

These were searched for articles containing MeSH terms or keywords relating to hand hygiene, physical distancing, face covering and direct observation. We did not include specific search terms for infectious disease as this was already the focus of the majority of papers investigating the three relevant behaviours.

For both search strategies we examined the reference sections of any pertinent studies and reviews for further references. 


\section{Eligibility criteria}

For aims one and two, we included studies that were published in English since January 2020, contained an observational measure of hand hygiene, physical distancing or face covering use in relation to COVID19, assessed these behaviours among the general public or healthcare workers, and contained original data. We excluded studies that contained only location-based data, for example, mobile phone data that measured where in space people were located (rather than what they were doing). We also excluded the use of used crowd density measurements where physical distancing of individuals within the crowd could not be determined. Studies were also excluded if they recorded impressionistic perceptions of behaviour rather than using a systematic method such as using unsystematic sampling methods or retrospective methods based on recall of behaviours.

For aim three, we included studies published in English (no date restrictions), that related to infectious disease control for any pathogen and that contained an observational measure of one or more of our defined behaviours compared to a self-report measure. We excluded studies that contained only selfreport or observational data.

\section{Study selection}

Titles and abstracts were independently double screened by two separate reviewers (RD screened all citations, FM screened half the citations and AFM screened the other half) using Sysrev Software to identify potentially eligible studies and record decisions. Full texts were then independently double screened (RD screened all citations, FM screened half the citations and AFM screened the other half), with any uncertainties resolved through discussion.

\section{Data extraction, items and risk of bias}

Two reviewers (RD, FM) extracted data from included studies. Study and participant characteristics were noted, including study design, sample size, number of opportunities for specified behaviours, location of 
observation, population characteristics and prevalence of adherence. Where needed, further details were sought by contacting study authors. For aims one and two, where papers contained a pre and post COVID-19 data collection period, only data collected during the COVID-19 pandemic were included in the narrative synthesis.

Studies were assessed for quality using the National Institutes of Health (NIH) Quality Assessment Tool for Observational Cohort and Cross Sectional Studies ${ }^{14}$.

\section{Results}

27,279 published papers were identified that included terms relating to COVID-19, and one or more terms relating to hand hygiene, face covering and social distancing. When the term 'observational' and related terms were added, 2589 papers were identified and these were screened for aims one and two, from which 105 were selected as potentially relevant to the review. Of these, 57 were excluded. A total of 48 studies met the inclusion criteria (See supplementary material). For aim three we screened 3,331 papers, from which 133 were deemed potentially relevant following abstract screening. Of these, 21 were included in the review.

Aim one: Quantity of studies using observational measures

We included $48^{15-62}$ studies containing an observation component during the COVID-19 pandemic. In total these included at least 116,169 participants and at least $36,060,422$ behavioural observational events.

Of the included studies, 39 used direct observers, one used an automated measurement to assess hand hygiene, five used video observations and three used mixed methods including; observation supplemented with a survey, observation supplemented with media data and in-person observation plus automated technology. 
Of the 48 included studies, 35 looked at wearing a face covering (five in healthcare workers, 30 in the general public), 17 studies looking at hand hygiene (12 in healthcare workers, five in the general public), and seven looked at physical distancing (one in healthcare workers and six in the general public).

Six studies contained an interventional component intended to improve adherence.

Studies had been conducted in Asia ( $n=18)$, North America ( $n=15)$, Europe (14), Africa $(n=2)$, and Australia $(n=1)$.

The most common setting for observation was in hospitals $(n=20)$, in stores or shopping centres $(n=12)$, on public streets ( $n=11)$, on public transport $(n=7)$, in parks $(n=4)$, high schools or universities $(n=3)$, community healthcare $(n=2)$ and residential care homes $(n=1)$.

For papers for which it could be determined ( $N=43$ ), sample size varied between 41 and 17,200 (median $=780)$.

The median number of behavioural observation events for each study was 1,020 , with a minimum of 41 and maximum of $35,362,136$. Two studies ${ }^{56,57}$ had a very high number of observations, one with $35,362,136$ opportunities and one with 593,118

Characteristics of all included studies are available in Supplementary material.

Aim two: Quality of studies using observational measures

Studies with interventions intended to improve adherence to protective behaviours $(n=6)$ were rated out of 11 relevant criteria on the NIH quality assessment checklist and studies with no interventions $(n=42)$ were rated out of eight relevant criteria. Studies with an intervention had a median score of 10, with a range of 8-11 (Figure 1). Studies without an intervention had a median score of 7 , with a range of 4-8 (Figure 2). Overall, studies in both groups generally had clearly defined study objectives, populations and variables, however very few studies reported any sample size or power estimates. 
medRxiv preprint doi: https://doi.org/10.1101/2021.12.22.21268226; this version posted December 23, 2021. The copyright holder for this preprint (which was not certified by peer review) is the author/funder, who has granted medRxiv a license to display the preprint in perpetuity.

It is made available under a CC-BY 4.0 International license .

Figure 1. Number of intervention studies displaying relevant aspects of NIH quality assessment tool

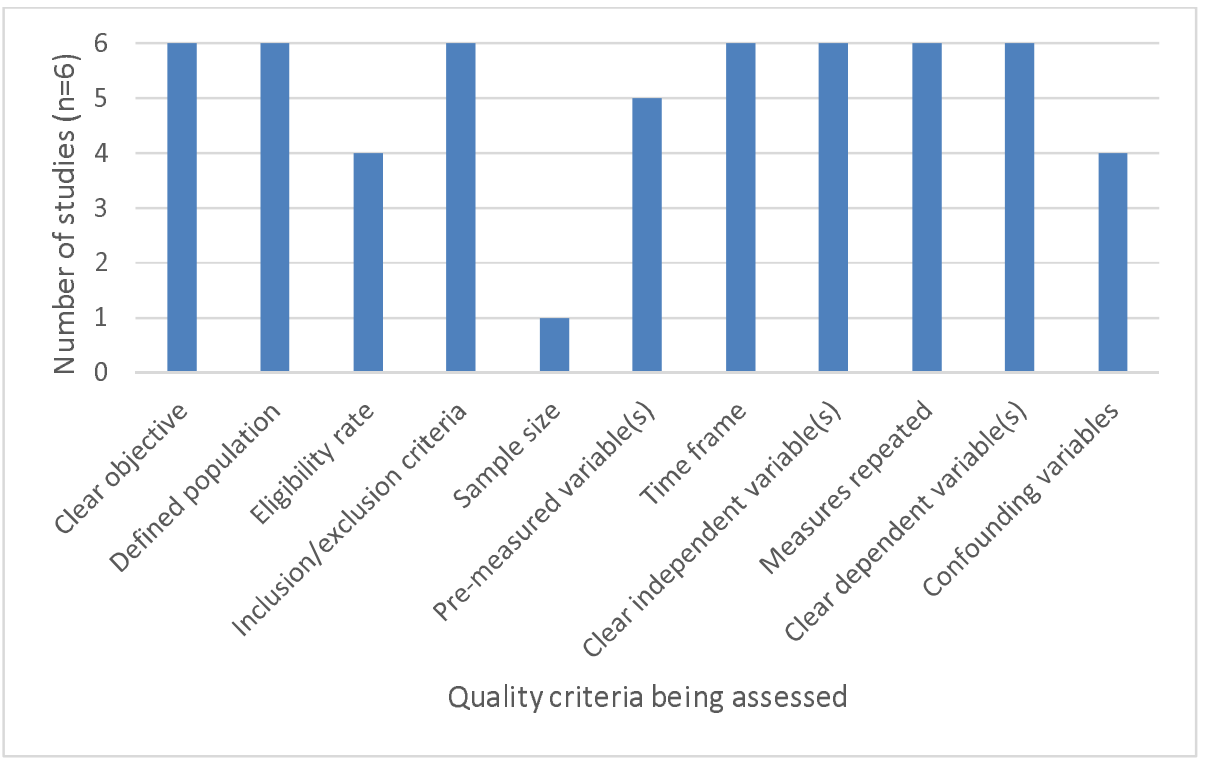

Figure 2. Number of non-intervention studies displaying relevant aspects of NIH quality assessment tool

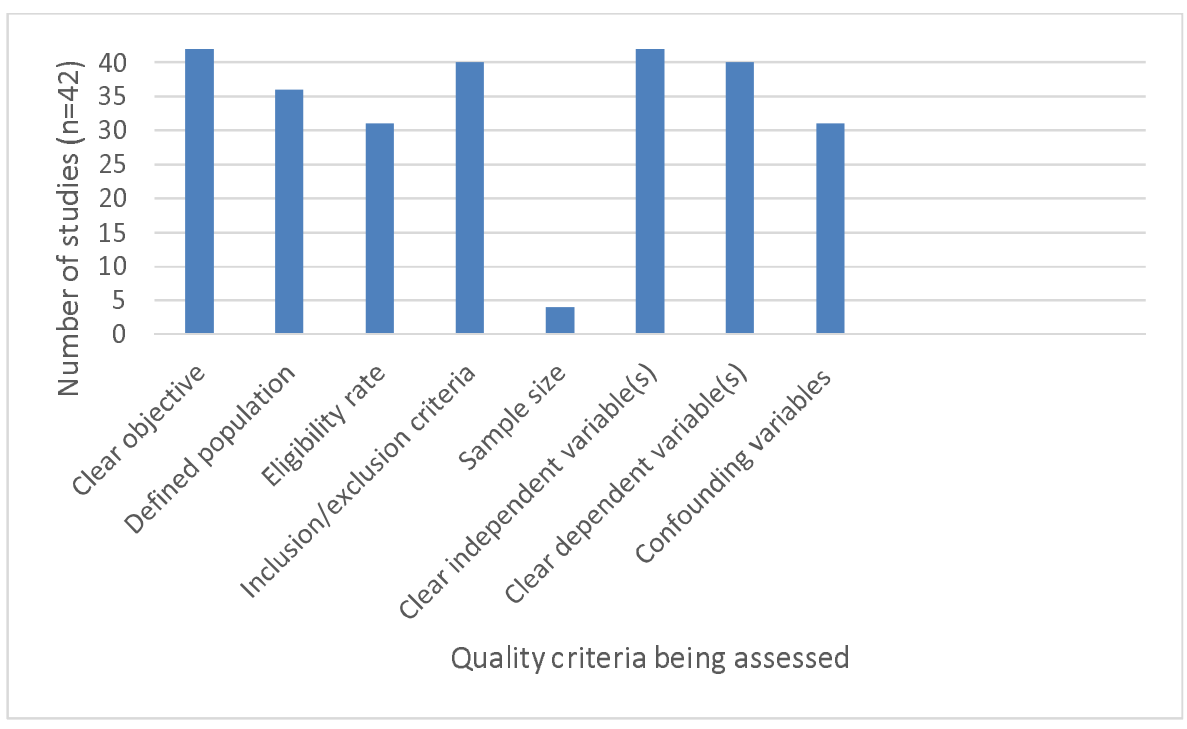

Aim three: Observational data vs self-report

In total, 21 studies contained both an observational and self-report component (see Table 1).

Characteristics of all included studies are available in the Supplementary material. Three studies

investigated COVID-19, while 18 investigated other infectious diseases or infectious disease practice pre- 
COVID-19. Of the three studies investigating behaviour during COVID-19, all three studied healthcare workers (one in Germany, one in the US and one in Thailand) and one also studied the general public (In Thailand). ${ }^{26,52,53}$. All three looked at hand hygiene adherence; one also looked at face covering use.

Self-reported and observed hand hygiene behaviour differed, with self-reported rates being around twice that of observed rates. The biggest difference seen in hand hygiene rates was $99 \%$ self-reported and $46 \%$ observed in a study of healthcare workers engaging in community-based patient care activities in the US ${ }^{52}$. Observed adherence in this study varied by the activity as well as by the period during the COVID-19 pandemic when assessments were made.

Self-reported and observed face covering wearing both had high rates of adherence, with $86 \%$ selfreported adherence among patients and $95.8 \%$ among healthcare workers in one Bangkok hospital, compared to $100 \%$ adherence when observed in both groups ${ }^{25}$.

Of 18 studies investigating other infectious diseases, most studies $(n=15)$ looked at hand hygiene in a healthcare worker population ${ }^{63,64,66,68-77,79.80}$, while two studied it in the general public ${ }^{65,78}$. One studied face covering use in healthcare workers ${ }^{67}$. None assessed physical distancing. Studies were conducted in Asia $(n=7)$, North America $(n=8)$, Europe $(n=3)$ and South America $(n=1)$.

Self-reported hand hygiene behaviour was higher than observed data in most studies ( $n=11)$. The greatest differences were $31 \%$ self-reported versus $6 \%$ observed hand hygiene in the general public in Peru $^{80}$, and $67 \%$ self-reported versus $15 \%$ observed hand hygiene in healthcare workers in a large hospital in Vietnam ${ }^{72}$. In the only study that examined it, face covering wearing was self-reported at $25 \%$ but observed at $1 \%$ in emergency department personnel at a Minnesota public teaching hospital ${ }^{67}$.

In only one paper was uptake of protective behaviours lower in self-report data than observed data, and this only applied to a small subset of participants, $4 \%$ of the total sample, who expressed that their hand hygiene adherence was between $0 \%$ and $10 \%$, compared to an observed rate of $35 \% .81 \%$ of the total 
medRxiv preprint doi: https://doi.org/10.1101/2021.12.22.21268226; this version posted December 23, 2021. The copyright holder for this preprint (which was not certified by peer review) is the author/funder, who has granted medRxiv a license to display the preprint in perpetuity. It is made available under a CC-BY 4.0 International license .

sample rated their hand hygiene adherence as between $80 \%$ and $90 \%$, comparable to the $90 \%$ adherence that was observed ${ }^{72}$.

Self-reported rates of behaviour matched observed rates in three studies, all studying hand hygiene: one study assessing healthcare workers' in a French university hospital ${ }^{67}$, one looking at medical students' $^{75}$, and one looking at healthcare workers' behaviour in an intensive care unit in South India ${ }^{81}$. 
Table 1. Summary of included studies which reported an observation and self-report measure of health protective behaviour

\begin{tabular}{|c|c|c|c|}
\hline Study & Population; location & Observed prevalence & Self-report prevalence \\
\hline Henry (1992) & $\begin{array}{l}\text { ED physicians ( } 12 \text { staff plus rotating residents), medical } \\
\text { students, nursing staff, and ancillary personnel; hospital } \\
\text { emergency department }\end{array}$ & $\begin{array}{l}\text { Overall face covering wearing } \\
\text { adherence: } 1.2 \%\end{array}$ & Overall face covering wearing adherence: $25.5 \%$ \\
\hline $\begin{array}{l}\text { Raymond } \\
\text { (2001) }\end{array}$ & Tattoo artists; Minneapolis and St. Paul, MN & Overall adherence was $71 \%$ & Overall adherence was $83 \%$ \\
\hline Cohen (2002) & Dermatologists; outpatient dermatology clinics in Israel & $\begin{array}{l}7(38.5 \%) \text { physicians washed hands only } \\
\text { after contact with suspected infected } \\
\text { material and } 1(7.7 \%) \text { before each } \\
\text { physical examination. Seven physicians } \\
(53.9 \%) \text { washed their hands } 1-5 \text { times a } \\
\text { day }\end{array}$ & $\begin{array}{l}19(37.3 \%) \text { washed their hands only following } \\
\text { contact with material suspected of being } \\
\text { contaminated, } 18(35.3 \%) \text { prior to examining every } \\
\text { patient, } 14(27.5 \%) \text { wash hands } 1-5 \text { times a day }\end{array}$ \\
\hline Moret (2004) & $\begin{array}{l}\text { Healthcare workers (physicians, nurses, and nurse } \\
\text { assistants); French university hospital }\end{array}$ & Overall adherence was $74 \%$ & Overall adherence was $74 \%$ \\
\hline Snow (2006) & $\begin{array}{l}60 \text { students enrolled in a certified nursing program; on } \\
\text { day } 1 \text { and day } 30 \text { of the clinical rotation. }\end{array}$ & $\begin{array}{l}\text { Day 1. Student hand hygiene:49.1\%. Day } \\
\text { 30. Student hand hygiene:52.3\%. }\end{array}$ & $\begin{array}{l}\text { Based on a scale of } 10-100.10 \text { being lowest possible } \\
\text { commitment to handwashing. On day } 30 \text { students } \\
\text { reported } 93.0 \text { before patient contact, } 95.5 \text { after } \\
\text { patient contact, } 84.9 \text { before donning gloves, and } \\
95.1 \text { after removal of gloves. }\end{array}$ \\
\hline $\begin{array}{l}\text { Alemayehu } \\
\text { (2009) }\end{array}$ & $\begin{array}{l}\text { Third and fourth year students; U.S. medical school } \\
\text { over one academic year at the beginning of every core } \\
\text { rotation (medicine, surgery, primary care medicine, } \\
\text { paediatrics, obstetrics/gynaecology, neurology, } \\
\text { psychiatry) }\end{array}$ & Overall adherence: $87.9 \%$ & Overall adherence: $87.9 \%$ \\
\hline
\end{tabular}




\begin{tabular}{|c|c|c|c|}
\hline $\begin{array}{l}\text { Soyemi, C } \\
(2010)\end{array}$ & $\begin{array}{l}\text { Doctors and nurses; three types of hospitals, i.e., public, } \\
\text { security forces, and private, in Eastern Saudi Arabia. }\end{array}$ & $\begin{array}{l}\text { Overall adherence for physicians: } 27 \% \\
\text { Overall adherence for nurses: } 29 \%\end{array}$ & $\begin{array}{l}\text { Likert scale. Physicians mean self-report was } \\
\text { 10.19/15 based on } 3 \text { hand hygiene opportunities, } \\
\text { and nurses was } 13.65 / 15 \text { based on } 3 \text { opportunities. }\end{array}$ \\
\hline Jessee (2013) & $\begin{array}{l}\text { Staff on } 3 \text { medical/surgical units; a 600-bed academic } \\
\text { medical centre (AMC) and a 110-bed community } \\
\text { medical centre (CMC) in the South-eastern United } \\
\text { States }\end{array}$ & $\begin{array}{l}\text { Hand hygiene before glove application, } \\
\text { was present in } 14 \% \text { of the CMC and } 21 \% \\
\text { of the AMC staff Hand hygiene on room } \\
\text { exit was } 25 \% \text { and } 78 \% \text { respectively. }\end{array}$ & $\begin{array}{l}\text { Hand hygiene before glove application was present } \\
\text { in } 63 \% \mathrm{CMC} \text { and } 50 \% \text { of AMC staff. Hand hygiene on } \\
\text { room exit } 16 \text { was } 84 \% \text { and } 94 \% \text { respectively. }\end{array}$ \\
\hline $\operatorname{Kim}(2013)$ & Doctors; healthcare settings. & $\begin{array}{l}\text { Adherence at baseline: } 49.7 \% \\
\text { Adherence in fourth quarter of } 2012 \text { : } \\
82.3 \%\end{array}$ & $\begin{array}{l}\text { Adherence at baseline: } 82.9 \% \text { Adherence in fourth } \\
\text { quarter of } 2012: 93.8 \%\end{array}$ \\
\hline Dalen (2013) & $\begin{array}{l}\text { Doctors ( } 13 \%) \text {, nurses }(70 \%) \text {, housekeeping staff }(9 \%) \\
\text { and visitors of patients ( } 9 \%) \text {; cancer hospital. }\end{array}$ & $\begin{array}{l}\text { Overall hand hygiene adherence, nurses: } \\
47 \% \text { Overall hand hygiene, doctors: } 51 \%\end{array}$ & $\begin{array}{l}\text { Overall hand hygiene adherence, nurses: } 88 \% \text { Overall } \\
\text { hand hygiene adherence, doctors: } 85 \%\end{array}$ \\
\hline $\begin{array}{l}\text { Lakshmi } \\
\text { (2015) }\end{array}$ & $\begin{array}{l}\text { Healthcare workers (predominantly nurses); ICU in an } \\
\text { oncology, BMT and neurosurgical centre in South India. }\end{array}$ & $\begin{array}{l}\text { Use of alcohol based hand rub } 98.5 \%, 5 \\
\text { moments of hand hygiene } 88.5 \%, 6 \text { steps } \\
\text { of hand hygiene } 65 \% \text {. }\end{array}$ & $\begin{array}{l}\text { Use of alcohol based hand rub } 98.5 \%, 5 \text { moments of } \\
\text { hand hygiene } 88.5 \%, 6 \text { steps of hand hygiene } 92.5 \%\end{array}$ \\
\hline $\begin{array}{l}\text { O'Donoghue } \\
(2016)\end{array}$ & $\begin{array}{l}\text { Healthcare workers, } 76 \text { radiographers, } 17 \text { nurses, and } \\
\text { nine healthcare assistants; a radiography unit. }\end{array}$ & $\begin{array}{l}\text { Overall adherence: } 29 \% \text { Post-test } \\
\text { adherence: } 51 \%\end{array}$ & $\begin{array}{l}\text { 'I wash my hands after using the rest room' was } \\
\text { rated a median of } 5 / 5 \text { on a Likert scale, quartiles } 4-5 \\
\text { before and after intervention. }\end{array}$ \\
\hline $\begin{array}{l}\text { Galiani } \\
(2016)\end{array}$ & $\begin{array}{l}\text { General public; households and community settings in } \\
\text { Peru }\end{array}$ & $\begin{array}{l}\text { Handwashing with soap was observed in } \\
\text { only } 16 \% \text { of the events that required it. } \\
20 \% \text { of faecal contact events, } 25 \% \text { of } \\
\text { eating events, } 6 \% \text { of child feeding } \\
\text { events, and } 10 \% \text { of food preparation } \\
\text { events. }\end{array}$ & $\begin{array}{l}\text { Less than } 50 \% \text { reported hand washing at times of } \\
\text { faecal contact. } 39 \% \text { reported with toilet use, } 34 \% \\
\text { cleaning up after children, } 68 \% \text { when cooking or with } \\
\text { food preparation and } 31 \% \text { when feeding a child. }\end{array}$ \\
\hline
\end{tabular}




\begin{tabular}{|c|c|c|c|}
\hline Keller (2018) & $\begin{array}{l}\text { ED staff, } 100 \text { nurses, } 13 \text { staff emergency physicians, } 25 \\
\text { medical interns, and various other professions (e.g. } \\
\text { maintenance and nursing assistants). Non-ED } \\
\text { consulting physicians and surgeons regularly visiting the } \\
\text { ED; in an Emergency Department of the University } \\
\text { Hospital Zurich }\end{array}$ & $\begin{array}{l}\text { Hand hygiene adherence during } \\
\text { baseline: } 56 \% \text {. Hand hygiene adherence } \\
\text { during intervention: } 64 \%\end{array}$ & $\begin{array}{l}\text { Hand hygiene adherence during baseline: } 4.12 \text {. Hand } \\
\text { hygiene during intervention } 4.03 \text { (on a Likert scale 1- } \\
5,5 \text { being always) }\end{array}$ \\
\hline Baloh (2019) & Healthca re workers; 3 large academic US hospitals & $\begin{array}{l}\text { Hand hygiene before gloving was } \\
\text { performed } 42 \% \text { of the time }\end{array}$ & $\begin{array}{l}\text { Hand hygiene before gloving was reported } 88 \% \text { of } \\
\text { the time }\end{array}$ \\
\hline Le (2019) & $\begin{array}{l}\text { Healthcare workers (physicians, nurses, care assistants, } \\
\text { and student nurses); large central hospital in Vietnam }\end{array}$ & $\begin{array}{l}\text { Physicians overall hand hygiene } \\
\text { adherence:14.6\%. Nurses overall hand } \\
\text { hygiene adherence: } 38.8 \%\end{array}$ & $\begin{array}{l}\text { Physicians overall hand hygiene adherence: } 67.2 \% \text {. } \\
\text { Nurses overall hand hygiene adherence: } 97.8 \%\end{array}$ \\
\hline $\begin{array}{l}\text { Woodard } \\
(2019)\end{array}$ & $\begin{array}{l}\text { Healthca re workers (nurses, physicians, technicians) } \\
\text { and patient interactions; 750-bed tertiary care } \\
\text { hospital in Baltimore, Maryland. }\end{array}$ & $\begin{array}{l}\text { Overall hand hygiene adherence: } 35 \% \text { of } \\
\text { all opportunities. Overall entry and exit } \\
\text { hand hygiene adherence: } 90 \%\end{array}$ & $\begin{array}{l}81 \% \text { of the sample estimated they miss performing } \\
\text { hand hygiene when they realize it should be } \\
\text { performed } 10 \%-20 \% \text { of the time. An additional } 11 \% \\
\text { reported missing hand hygiene } 30 \%-40 \% \text { of the time. } \\
4 \% \text { estimated they missed performing hand hygiene } \\
90 \%-100 \% \text { of the time. }\end{array}$ \\
\hline $\begin{array}{l}\text { Kelcikova } \\
\text { (2019) }\end{array}$ & $\begin{array}{l}\text { Doctors and nurses; eight hospitals in two countries } \\
\text { (five in Slovakia and three in the Czech Republic) }\end{array}$ & Overall adherence: $67.7 \%$ & Overall adherence: $74.0 \%$ \\
\hline $\begin{array}{l}\text { Derksen } \\
(2020)\end{array}$ & $\begin{array}{l}\text { Healthcare workers (physicians, midwives, and nurses); } \\
\text { two German obstetric hospitals during and after the } \\
\text { onset of the COVID-19 pandemic. }\end{array}$ & $\begin{array}{l}\text { After declaration of pandemic overall } \\
\text { hand hygiene adherence: } 95 \% \text {. After } \\
\text { body fluid exposure risk: } 100 \% \text {. }\end{array}$ & $\begin{array}{l}\text { After declaration of pandemic overall hand hygiene } \\
\text { adherence: } M=5.03, S D=0.75 \text { on a } 6 \text { point scale. } \\
\text { After body fluid exposure risk: } M=5.66, S D=0.67 \text {. }\end{array}$ \\
\hline
\end{tabular}




\begin{tabular}{|c|c|c|c|}
\hline $\begin{array}{l}\text { Dowding } \\
(2020)\end{array}$ & $\begin{array}{l}400 \text { U.S. home care nurses; community care } \\
\text { organization }\end{array}$ & Overall hand hygiene adherence: $45.6 \%$. & Overall hand hygiene adherence: $99.4 \%$ \\
\hline $\begin{array}{l}\text { Skuntaniyom } \\
\text { (2021) }\end{array}$ & $\begin{array}{l}119 \text { healthcare workers (mostly nurses and laboratory } \\
\text { workers) and } 100 \text { general public (mostly administrative } \\
\text { workers and professionals); Thailand in two inpatient } \\
\text { hospitals providing COVID-19 testing and treatment. }\end{array}$ & $\begin{array}{l}100 \% \text { of patients and } 100 \% \text { healthcare } \\
\text { workers wore face covering correctly. } \\
35.2 \% \text { of patients and } 40.0 \% \text { of } \\
\text { healthcare workers correctly cleaned all } \\
\text { a reas of both hands. }\end{array}$ & $\begin{array}{l}86 \% \text { of patients and } 95.8 \% \text { of healthcare workers } \\
\text { wore a face covering correctly. } 67 \% \text { of patients and } \\
84.9 \% \text { of healthcare workers reported adhering to } \\
\text { hand hygiene. }\end{array}$ \\
\hline
\end{tabular}


medRxiv preprint doi: https://doi.org/10.1101/2021.12.22.21268226; this version posted December 23, 2021. The copyright holder for this preprint (which was not certified by peer review) is the author/funder, who has granted medRxiv a license to display the preprint in perpetuity.

It is made available under a CC-BY 4.0 International license .

\section{Quality assessment of Non COVID-19 Studies}

Studies with interventions intended to improve adherence to protective behaviours $(n=2)$ were rated out of 11 relevant criteria on the NIH quality assessment checklist and studies with no interventions $(n=16)$ were rated out of eight relevant criteria. Studies with an intervention had a median score of 7 , with a range of 6-9 (Figure 3). Studies without an intervention had a median score of 6 , with a range of 1-8 (Figure 4). Overall, studies in both groups generally had clearly defined study objectives,

populations and variables, however very few studies reported any sample size or power estimates.

Figure 3. Number of non-COVID-19 intervention studies displaying relevant aspects of NIH quality assessment tool

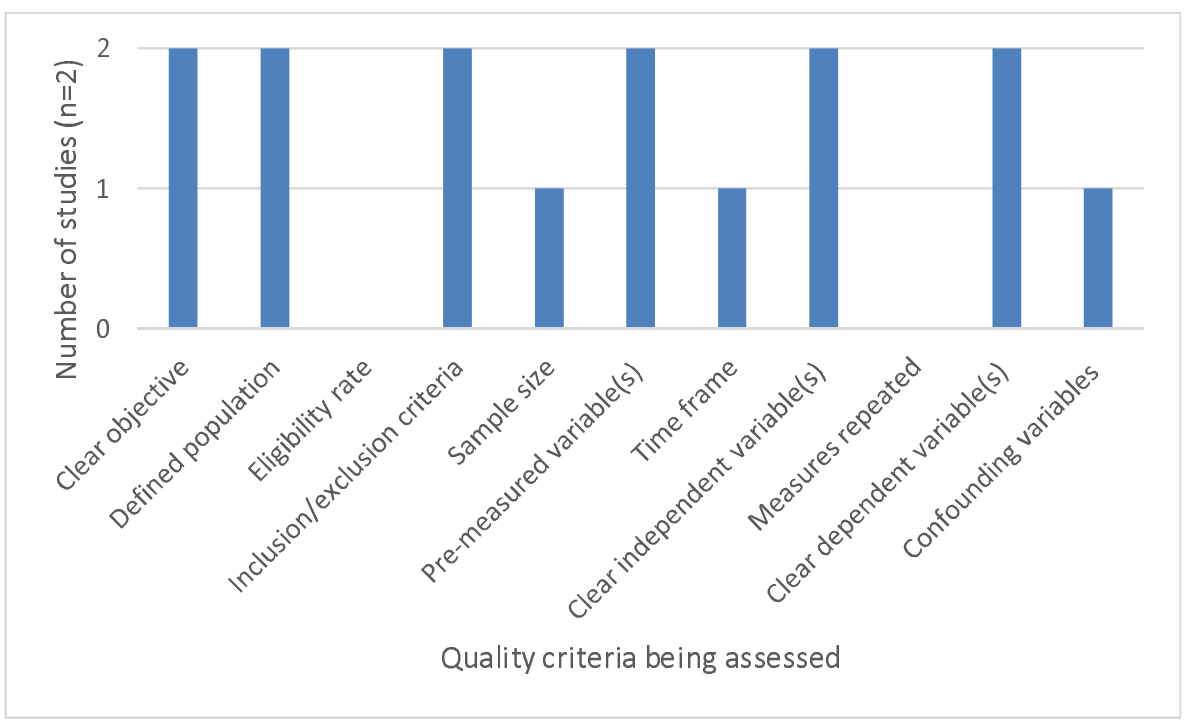

Figure 4. Number of non-COVID-19 non-intervention studies displaying relevant aspects of NIH quality assessment tool 


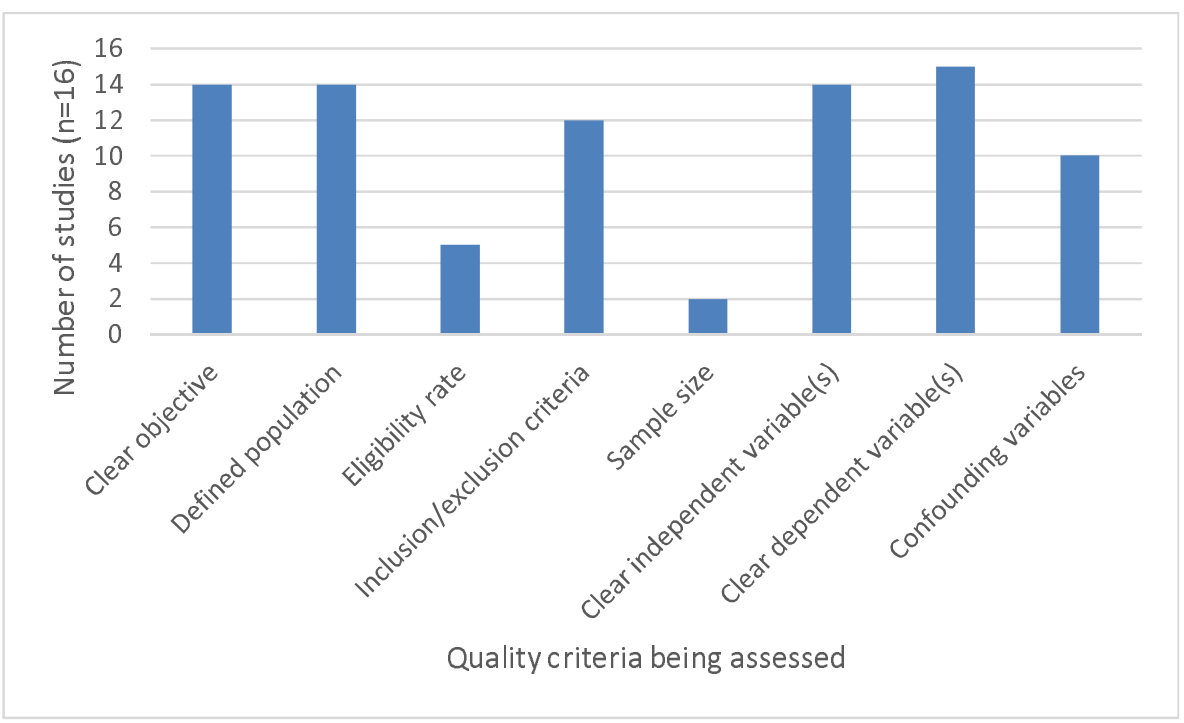

\section{Discussion}

Improving uptake of health protective behaviours is an important public health challenge, not only for COVID-19, but for infectious disease prevention more widely. Face coverings, hand hygiene and maintaining physical distance have all been identified as effective infection control strategies that have relatively few downsides in comparison to more far-reaching interventions such as society-wide 'lockdowns.' ${ }^{12}$ Identifying ways to achieve good adherence to such measures requires that we are first able to measure adherence accurately. Though self-report can be a useful proxy for behaviour, our review suggests that academic research has become overly reliant on it, so much so that although we identified 27, 279 papers which included terms related to COVID-19 and to hand hygiene, face covering or social distancing, just 48 of these papers $(<0.2 \%)$ actually studied the behaviour in question objectively.

It is likely that several factors influence the way in which behaviour is measured. Speed, cost, ease and the ability to explore associations with other variables which may be best measured via self-report (such as, for example, trust in government, exposure to conspiracy theories or the perceived efficacy of an intervention) are all valid reasons for opting to use self-report over observation. Indeed, the importance of ease as a factor likely explains why only seven studies have attempted to assess 
physical distancing using observational techniques while 35 have looked at face coverings: it is difficult for an observer to judge distance between two people and to identify whether people need to maintain distance from each other (e.g. if they do or do not live in the same household), but easier to assess whether they are wearing a face covering. Nonetheless, our review also points to the dangers of over-reliance on self-report. The 21 studies that we identified which compared self-report and observed behaviour repeatedly demonstrated that self-report over-estimates hand hygiene behaviour, sometimes dramatically so, while evidence for the validity of self-reported distancing and face covering use is limited in the current literature. Although outside the date range for our search, two recent pre-prints support this point for hand hygiene and extend the evidence of a self-report gap to include face covering and distancing. One study demonstrated that self-reports of "always" wearing a face covering when in specific public spaces in a national UK Government-funded survey matched observed behaviour in those locations, but that an additional $23 \%$ of people reported "sometimes" wearing face coverings in these situations, something which could not be accounted for in the observations. ${ }^{81}$ The other study, of a single university campus in the UK, found that while $68 \%$ of survey respondents reported always cleaning their hands while entering a university building, observation of the only entrance to the main campus building found the true rate to be $16 \%^{82}$. Reported and observed rates for distancing were also discordant (49\% vs $7 \%$ ) while the gap for wearing a face covering was smaller but still noticeable (90\% vs $82 \%$ ). While multiple factors may account for these discrepancies ${ }^{83}$, recall bias and social desirability would seem most likely to lead to inflated estimates of behaviours such as hand hygiene and physical distancing. The relative novelty of face coverings for many people, the limited number of occasions they need to be worn during the day for many members of the general public and their greater salience and hence ease of recall may partly mitigate these biases and explain why self-reported wearing of a covering may be a more reliable measure of behaviour than self-reported hand hygiene or distancing.

Notably, the quality of studies that included an observational measure was generally good in most respects. The one exception was that relatively few studies provided a sample size justification. We 
medRxiv preprint doi: https://doi.org/10.1101/2021.12.22.21268226; this version posted December 23, 2021. The copyright holder for this preprint (which was not certified by peer review) is the author/funder, who has granted medRxiv a license to display the preprint in perpetuity.

It is made available under a CC-BY 4.0 International license .

suspect this is linked to the difficulty of setting a pre-determined sample size in advance of a naturalistic study. For example, it can be difficult to predict how many people will pass by an observer over a set period of time. The relatively high quality may reflect the tendency for authors who choose to take the difficult route of evaluating behaviour via an objective measure to have also considered other ways of maximising the quality of their study.

\section{Suggestions for future research}

Plenty of scope exists for future work to expand this literature. First, there is a pressing need to establish the validity of self-reported behaviour. At present, the limited literature that exists focusses almost entirely on hand hygiene. During the COVID-19 pandemic we found no studies comparing selfreport and observational data for physical distancing and only one for the use of face coverings, although more work in this area is starting to appear ${ }^{81,82}$. Future work should test approaches to improve the validity of self-report data and also test whether the correlates of self-reported behaviour (which are the basis for many policy recommendations and proposed interventions) can be replicated as correlates of observed behaviour. Consideration should be given to the potential differences in validity that may be observed across population and settings. For example, in the studies that we reviewed, observed adherence tended to be higher in studies of healthcare workers than in general population samples.

Second, our review focussed solely on three behaviours: hand hygiene, face covering use and physical distancing. While important, these are only a subset of the complex set of behaviours that members of the public have been encouraged to adopt during the COVID-19 pandemic. We have not systematically reviewed the literature on the validity of self-report measures of, for example, testing uptake or selfisolation, but have no reason to suspect that self-report is more valid for these behaviours, given that there is substantial social desirability involved and that, for some of them, research participants may technically be liable to legal action if they admit to non-adherence. Nonetheless, key studies on these outcomes rely entirely on self-report ${ }^{84,85}$. The one notable exception to this list is vaccination, a 
memorable, binary outcome for which self-report has been shown to be reasonably, though not entirely, valid ${ }^{86,87}$.

Third, while our review may give the impression that observation is a single 'gold standard' metric for behaviour, it is clear that there are multiple methods of observation. We identified methods including direct study of behaviours by trained observers, video observation, automated technology, and the use of newly developed technology using $\mathrm{Al}$ and machine learning in place of an observer. The use of such technology has been demonstrated with face covering wearing studies, as well as studies that

measure crowd density with social distancing within the crowd data ${ }^{88,89,90}$. These techniques all have their pros and cons in terms of intrusiveness, cost, capacity, ability to identify behaviours that may be partially obscured and so on. A 'one-size-fits-all approach' may not be possible. Nonetheless, further work to develop a set of standardised observational protocols for key outcomes may assist in promoting the use of such techniques and allowing better comparison between studies.

\section{Limitations}

Several limitations should be considered for this systematic review. First, our conclusions are limited by the availability of data in the literature. The relative absence of observational data relating to face covering wearing or physical distancing is an important result in its own right, but also limits our ability to assess the adequacy of self-report for these behaviours. Second, while we made efforts to search widely for relevant studies, including in COVID-19 specific databases, it is possible that we missed some studies which used terminology relating to an observational method that we did not include in our search. Given the rapidity with which the COVID-19 literature has expanded, with approximately a quarter of a million papers appearing in Scopus alone in less than two years, it is likely that additional studies will have been added to the databases that we searched in the time taken between completing our search and publication of this paper. 
In this review, we have not attempted to pool the rates of behaviour observed in the various studies.

The differing contexts in the studies we included means that any pooled estimate would not be meaningful. For example, it is probably not useful to compare rates of observed hand hygiene among healthcare workers working on COVID-19 wards ${ }^{26}$ with those among high school students attending their graduations ${ }^{49}$.

\section{Conclusions}

The COVID-19 pandemic witnessed an explosion in research covering every aspect of the crisis. Within the field of behavioural science, there has been a heavy focus on ways to promote behaviours believed to reduce infection transmission. Almost all of these studies have measured whether people say they have engaged in specific behaviours. Few have measured the behaviour itself. This is problematic. For hand hygiene, observed adherence tends to be substantially lower than estimates obtained via self-report. There are few studies that have tested the validity of self-reported face covering use or physical distancing, but these also suggest that self-reports tend to be biased. Future research in this field should make greater use of observational methods where possible and should carefully consider the validity of any self-report measure where this is not possible.

\section{Funding}

This study was funded by the National Institute for Health Research Health Protection Research Unit (NIHR HPRU) in Emergency Preparedness and Response, a partnership between the UK Health Security Agency, King's College London and the University of East Anglia. Alex F Martin is supported by the Economic and Social Research Council Grant Number ES/J500057/1. The views expressed are those of the author(s) and not necessarily those of the NIHR, UK Health Security Agency or the Department of Health and Social Care. 


\section{References}

1. Scholz U, Freund AM. Determinants of protective behaviours during a nationwide lockdown in the wake of the COVID-19pandemic. Br J Health Psychol. 2021;26(3):935957. doi:10.1111/bjhp.12513

2. Center for Disease Control. Social Distancing. Available at https://www.cdc.gov/coronavirus/2019- ncov/prevent-getting-sick/socialdistancing.html (Accessed 09 June 2021)

3. https://www.bmj.com/content/375/bmj-2021-068302

4. Williams SN, Armitage CJ, Tampe T, Dienes KD. Public perceptions of non-adherence to COVID-19measures by self and others in the United Kingdom. MedRxiv [Preprint]. 2020;10.1101/2020.11.17.20233486

5. Tesfaye W, Peterson G. Self-reported medication adherence measurement tools: Some options to avoid a legal minefield [published online ahead of print, 2021 Aug 25]. J Clin Pharm Ther. 2021;10.1111/jcpt.13515. doi:10.1111/jcpt.13515

6. MANGTANI P, SHAH A, ROBERTS JA. Validation of influenza and pneumococcal vaccine status in adults based on self-report. Epidemiology and Infection. 2007;135(1):139-143. doi:10.1017/S0950268806006479

7. Kormos, C. \& Gifford, R. The validity of self-report measures of proenvironmental behavior: A meta-analytic review. J. Environ. Psychol.2014. 40, 359-371

8. Dobbinson SJ, Jamsen K, Dixon HG, et al. Assessing population-wide behaviour change: concordance of 10-year trends in self-reported and observed sun protection. Int J Public Health. 2014;59(1):157-166. doi:10.1007/s00038-013-0454-5

9. Prince SA, Adamo KB, Hamel ME, Hardt J, Connor Gorber S, Tremblay M. A comparison of direct versus self-report measures for assessing physical activity in adults: a systematic review. Int J Behav Nutr Phys Act. 2008;5:56. Published 2008 Nov 6. doi:10.1186/1479-5868-5-56

10. Smith LE, Mottershaw AL, Egan M, Waller J, Marteau TM, Rubin GJ. Correction: The impact of believing you have had COVID-19on self-reported behaviour: Cross-sectional survey. PLoS One. 2021;16(2):e0248076. Published 2021 Feb 25. doi:10.1371/journal.pone.0248076

11. Jeffrey B, Walters CE, Ainslie KEC, et al. Anonymised and aggregated crowd level mobility data from mobile phones suggests that initial compliance with COVID-19social distancing interventions was high and geographically consistent across the UK. Wellcome Open Res. 2020;5:170. Published 2020 Jul 17. doi:10.12688/wellcomeopenres.15997.1

12. Chen L, Grimstead I, Bell D, et al. Estimating Vehicle and Pedestrian Activity from Town and City Traffic Cameras. Sensors (Basel). 2021;21(13):4564. Published 2021 Jul 3. doi:10.3390/s21134564

13. Glampson B, Brittain J, Kaura A, Mulla A, Mercuri L, Brett SJ, Aylin P, Sandall T, Goodman I, Redhead J, Saravanakumar K, Mayer EK. North West London COVID- 
19Vaccination Programme: Real-world evidence for Vaccine uptake and effectiveness:

Retrospective Cohort Study. JMIR Public Health Surveill. 2021 Jul 8. doi:

10.2196/30010. Epub ahead of print. PMID: 34265740.

14. NIH. 2021. Study Quality Assessment Tool. Available at:https://www.nhlbi.nih.gov/health-topics/study-quality-assessment-tools (Accessed 1 October 2021).

15. Ragusa R, Marranzano M, Lombardo A, Quattrocchi R, Bellia MA, Lupo L. Has the COVID-19 19 Virus Changed Adherence to Hand Washing among Healthcare Workers?. Behav Sci (Basel). 2021;11(4):53. Published 2021 Apr 15. doi:10.3390/bs11040053

16. Shiraly R, Shayan Z, McLaws ML. Face touching in the time of COVID-19in Shiraz, Iran. Am J Infect Control. 2020;48(12):1559-1561. doi:10.1016/j.ajic.2020.08.009

17. Supehia S, Singh V, Sharma T, Khapre M, Gupta PK. Rational use of face mask in a tertiary care hospital setting during COVID-19pandemic: An observational study. Indian J Public Health. 2020;64(Supplement):S225-S227. doi:10.4103/ijph.IJPH_493_20

18. Precioso J, Samorinha C, Alves R. Prevention measures for COVID-19in retail food stores in Braga, Portugal. Pulmonology. 2021;27(3):260-261.

doi:10.1016/j.pulmoe.2020.06.009

19. Liebst LS, Ejbye-Ernst $P$, de Bruin M, Thomas J, Lindegaard MR. Face-touching behaviour as a possible correlate of mask-wearing: A video observational study of public place incidents during the COVID-19pandemic [published online ahead of print, 2021 Apr 5]. Transbound Emerg Dis. 2021;10.1111/tbed.14094. doi:10.1111/tbed.14094

20. Precioso J, Samorinha C. Prevention of COVID-19in retail food stores in Portugal: The importance of regulations in behavioural change. Aten Primaria. 2021;53(2):101953. doi:10.1016/j.aprim.2020.07.011

21. Tam VCW, Tam SY, Khaw ML, Law HKW, Chan CPL, Lee SWY. Behavioural insights and attitudes on community masking during the initial spread of COVID-19in Hong Kong. Hong Kong Med J. 2021;27(2):106-112. doi:10.12809/hkmj209015

22. Ganczak M, Pasek O, Duda-Duma $Ł$, Świstara D, Korzeń M. Use of masks in public places in Poland during SARS-Cov-2 epidemic: a covert observational study. BMC Public Health. 2021;21(1):393. Published 2021 Feb 23. doi:10.1186/s12889-021-10418-3

23. Barrios LC, Riggs MA, Green RF, et al. Observed Face Mask Use at Six Universities United States, September-November 2020. MMWR Morb Mortal Wkly Rep. 2021;70(6):208-211. Published 2021 Feb 12. doi:10.15585/mmwr.mm7006e1

24. Datta R, Glenn K, Pellegrino A, et al. Increasing face-mask compliance among healthcare personnel during the coronavirus disease 2019 (COVID-19-19) pandemic [published online ahead of print, 2021 May 3]. Infect Control Hosp Epidemiol. 2021;1-7. doi:10.1017/ice.2021.205

25. Maude RR, Jongdeepaisal M, Skuntaniyom S, et al. Improving knowledge, attitudes and practice to prevent COVID-19transmission in healthcare workers and the public in 
Thailand. BMC Public Health. 2021;21(1):749. Published 2021 Apr 18.

doi:10.1186/s12889-021-10768-y

26. Avo C, Cawthorne KR, Walters J, Healy B. An observational study to identify types of personal protective equipment breaches on inpatient wards. J Hosp Infect.

2020;106(1):208-210. doi:10.1016/j.jhin.2020.06.024

27. Haischer MH, Beilfuss R, Hart MR, et al. Who is wearing a mask? Gender-, age-, and location-related differences during the COVID-19pandemic. PLoS One.

2020;15(10):e0240785. Published 2020 Oct 15. doi:10.1371/journal.pone.0240785

28. Beckage B, Buckley TE, Beckage ME. Prevalence of Face Mask Wearing in Northern Vermont in Response to the COVID-19Pandemic. Public Health Rep. 2021;136(4):451456. doi:10.1177/00333549211009496

29. Dzisi EKJ, Dei OA. Adherence to social distancing and wearing of masks within public transportation during the COVID-19 19 pandemic. Transp Res Interdiscip Perspect. 2020;7:100191. doi:10.1016/j.trip.2020.100191

30. Gunasekaran, S.S.; Gunasekaran, S.S.; Gunasekaran, G.H.; Zaimi, N.S.I.; Halim, N.A.A.; Halim, F.H.A. Factors associated with incorrect facemask use among individuals visiting high-risk locations during COVID-19pandemic. Int. J. Public Health 2020, 18, 38-48.

31. Cumbo E, Scardina GA. Management and use of filter masks in the "none-medical" population during the COVID-19period. Saf Sci. 2021;133:104997.

doi:10.1016/j.ssci.2020.104997

32. Chutiphimon H, Thipsunate A, Cherdchim A, et al. Effectiveness of Innovation Media for Improving Physical Distancing Compliance during the COVID-19Pandemic: A QuasiExperiment in Thailand. Int J Environ Res Public Health. 2020;17(22):8535. Published 2020 Nov 17. doi:10.3390/ijerph17228535

33. Guellich A, Tella E, Ariane M, Grodner C, Nguyen-Chi HN, Mahé E. The face masktouching behavior during the COVID-19pandemic: Observational study of public transportation users in the greater Paris region: The French-mask-touch study. J Transp Health. 2021;21:101078. doi:10.1016/j.jth.2021.101078

34. Newman MG. An Observational Study of Mask Guideline Compliance In An Outpatient OB/GYN Clinic Population. Eur J Obstet Gynecol Reprod Biol. 2020;255:268-269. doi:10.1016/j.ejogrb.2020.10.048

35. Wichaidit W, Naknual S, Kleangkert N, Liabsuetrakul T. Installation of pedal-operated alcohol gel dispensers with behavioral nudges and changes in hand hygiene behaviors during the COVID-19pandemic: A hospital-based quasi-experimental study. J Public Health Res. 2020;9(4):1863. Published 2020 Oct 26. doi:10.4081/jphr.2020.1863

36. Rahimi Z, Shirali GA, Araban M, Mohammadi MJ, Cheraghian B. Mask use among pedestrians during the COVID-19pandemic in Southwest Iran: an observational study on 10,440 people. BMC Public Health. 2021;21(1):133. Published 2021 Jan 14. doi:10.1186/s12889-020-10152-2 
37. Chen YJ, Qin G, Chen J, et al. Comparison of Face-Touching Behaviors Before and During the Coronavirus Disease 2019 Pandemic. JAMA Netw Open. 2020;3(7):e2016924. Published 2020 Jul 1. doi:10.1001/jamanetworkopen.2020.16924

38. Zhou Q, Lai X, Zhang X, Tan L. Compliance measurement and observed influencing factors of hand hygiene based on COVID-19guidelines in China. Am J Infect Control. 2020;48(9):1074-1079. doi:10.1016/j.ajic.2020.05.043

39. Neuwirth MM, Mattner F, Otchwemah R. Adherence to personal protective equipment use among healthcare workers caring for confirmed COVID-19and alleged non-COVID19patients. Antimicrob Resist Infect Control. 2020;9(1):199. Published 2020 Dec 10. doi:10.1186/s13756-020-00864-w

40. Kungurova, Y., Mera, R., Brewster, E., Ali, K., \& Fakoya, A. O. (2020). COVID-19and face mask use: A St. kitts case study. Open access maced. Journal of Medical Sciences., 8, 346- 352. https://doi.org/10.17533/udea.iee.v38n2e13

41. Natnael T, Alemnew $Y$, Berihun $G$, et al. Facemask wearing to prevent COVID19 transmission and associated factors among taxi drivers in Dessie City and Kombolcha Town, Ethiopia. PLoS One. 2021;16(3):e0247954. Published 2021 Mar 12. doi:10.1371/journal.pone.0247954

42. Parikh A, Kondapalli S. FACE COVERING ADHERENCE IN AN OUTPATIENT OPHTHALMOLOGY CLINIC DURING COVID-19-19. Ophthalmic Epidemiol. 2021;28(4):365-368. doi:10.1080/09286586.2020.1866022

43. Kellerer JD, Rohringer M, Deufert D. Behavior in the use of face masks in the context of COVID-19-19. Public Health Nurs. 2021;38(5):862-868. doi:10.1111/phn.12918

44. Gosadi IM, Daghriri KA, Shugairi AA, et al. Community-based observational assessment of compliance by the public with COVID-1919 preventive measures in the south of Saudi Arabia. Saudi J Biol Sci. 2021;28(3):1938-1943. doi:10.1016/j.sjbs.2020.12.045

45. Tamamoto KA, Rousslang ND, Ahn HJ, Better HE, Hong RA. Public Compliance with Face Mask Use in Honolulu and Regional Variation. Hawaii J Health Soc Welf. 2020;79(9):268-271.

46. Jabbari P, Taraghikhah N, Jabbari F, Ebrahimi S, Rezaei N. Adherence of the General Public to Self-Protection Guidelines During the COVID-19Pandemic [published online ahead of print, 2020 Nov 18]. Disaster Med Public Health Prep. 2020;1-4. doi:10.1017/dmp.2020.445

47. Deschanvres $C$, Haudebourg T, Peiffer-Smadja N, et al. How do the general population behave with facemasks to prevent COVID-19in the community? A multi-site observational study. Antimicrob Resist Infect Control. 2021;10(1):61. Published 2021 Mar 29. doi:10.1186/s13756-021-00927-6

48. Sun Y, Lam TH, Cheung YTD, et al. First Report on Smoking and Infection Control Behaviours at Outdoor Hotspots during the COVID-19Pandemic: An Unobtrusive Observational Study. Int J Environ Res Public Health. 2021;18(3):1031. Published 2021 Jan 25. doi:10.3390/ijerph18031031 
49. Mueller AS, Diefendorf S, Abrutyn S, et al. Youth Mask-Wearing and Social-Distancing Behavior at In-Person High School Graduations During the COVID-19Pandemic. J Adolesc Health. 2021;68(3):464-471. doi:10.1016/j.jadohealth.2020.12.123

50. C. Cong, Z. Yang, Y. Song and M. Pagnucco, "Towards Enforcing Social Distancing Regulations with Occlusion-Aware Crowd Detection," 2020 16th International Conference on Control, Automation, Robotics and Vision (ICARCV), 2020, pp. 297-302, doi: 10.1109/ICARCV50220.2020.9305507.

51. Derksen C, Keller FM, Lippke S. Obstetric Healthcare Workers' Adherence to Hand Hygiene Recommendations during the COVID-19Pandemic: Observations and SocialCognitive Determinants. Appl Psychol Health Well Being. 2020;12(4):1286-1305. doi:10.1111/aphw.12240

52. Dowding D, McDonald MV, Shang J. Implications of a US study on infection prevention and control in community settings in the UK. Br J Community Nurs. 2020;25(12):578583. doi:10.12968/bjcn.2020.25.12.578

53. Mukherjee R, Roy P, Parik M. Achieving Perfect Hand Washing: an Audit Cycle with Surgical Internees [published online ahead of print, 2020 Oct 6]. Indian J Surg. 2020;17. doi:10.1007/s12262-020-02619-8

54. Au JKL, Suen LKP, Lam SC. Observational study of compliance with infection control practices among healthcare workers in subsidized and private residential care homes. BMC Infect Dis. 2021;21(1):75. Published 2021 Jan 14. doi:10.1186/s12879-02105767-8

55. Chuang, Y., and Liu, J. C. E. (2020). Who wears a mask? Gender differences in risk behaviors in the COVID-19early days in Taiwan. Econ. Bull. 40, 2619-2627. Available online at: https://ideas.repec.org/a/ebl/ecbull/eb-20-00882.html

56. Moore LD, Robbins G, Quinn J, Arbogast JW. The impact of COVID-19pandemic on hand hygiene performance in hospitals. Am J Infect Control. 2021;49(1):30-33. doi:10.1016/j.ajic.2020.08.021

57. Hess OCR, Armstrong-Novak JD, Doll M, et al. The impact of coronavirus disease 2019 (COVID-19-19) on provider use of electronic hand hygiene monitoring technology. Infect Control Hosp Epidemiol. 2021;42(8):1007-1009. doi:10.1017/ice.2020.1336

58. Choi UY, Kwon YM, Kang HJ, et al. Surveillance of the infection prevention and control practices of healthcare workers by an infection control surveillance-working group and a team of infection control coordinators during the COVID-19pandemic. J Infect Public Health. 2021;14(4):454-460. doi:10.1016/j.jiph.2021.01.012

59. Roshan R, Feroz AS, Rafique Z, Virani N. Rigorous Hand Hygiene Practices Among Health Care Workers Reduce Hospital-Associated Infections During the COVID-19Pandemic. J Prim Care Community Health. 2020;11:2150132720943331. doi:10.1177/2150132720943331

60. Clinton M, Sankar J, Ramesh V, Madhusudan M. Use of Proper Personal Protective Measures among Parents of Children Attending Outpatient Department - An 
Observational Study. Indian J Pediatr. 2021;88(5):480. doi:10.1007/s12098-020-036241

61. McDonald MV, Brickner C, Russell D, et al. Observation of Hand Hygiene Practices in Home Health Care. J Am Med Dir Assoc. 2021;22(5):1029-1034.

doi:10.1016/j.jamda.2020.07.031

62. Miller ZD, Freimund W, Dalenberg D, Vega M. Observing COVID-19related behaviors in a high visitor use area of Arches National Park. PLoS One. 2021;16(2):e0247315.

Published 2021 Feb 22. doi:10.1371/journal.pone.0247315

63. Snow M, White GL Jr, Alder SC, Stanford JB. Mentor's hand hygiene practices influence student's hand hygiene rates. Am J Infect Control. 2006;34(1):18-24.

doi:10.1016/j.ajic.2005.05.009

64. Cohen HA, Kitai E, Levy I, Ben-Amitai D. Handwashing patterns in two dermatology clinics. Dermatology. 2002;205(4):358-361. doi:10.1159/000066421

65. Raymond MJ, Pirie PL, Halcón LL. Infection control among professional tattooists in Minneapolis and St. Paul, MN. Public Health Rep. 2001;116(3):249-256. doi:10.1093/phr/116.3.249

66. Moret L, Tequi B, Lombrail P. Should self-assessment methods be used to measure compliance with handwashing recommendations? A study carried out in a French university hospital. Am J Infect Control. 2004;32(7):384-390.

doi:10.1016/j.ajic.2004.02.004

67. Henry K, Campbell S, Maki M. A comparison of observed and self-reported compliance with universal precautions among emergency department personnel at a Minnesota public teaching hospital: implications for assessing infection control programs. Ann Emerg Med. 1992;21(8):940-946. doi:10.1016/s0196-0644(05)82932-4

68. Baloh J, Thom KA, Perencevich E, et al. Hand hygiene before donning nonsterile gloves: Healthcareworkers' beliefs and practices. Am J Infect Control. 2019;47(5):492-497. doi:10.1016/j.ajic.2018.11.015

69. Jessee MA, Mion LC. Is evidence guiding practice? Reported versus observed adherence to contact precautions: a pilot study. Am J Infect Control. 2013;41(11):965-970. doi:10.1016/j.ajic.2013.05.005

70. Le CD, Lehman EB, Nguyen TH, Craig TJ. Hand Hygiene Compliance Study at a Large Central Hospital in Vietnam. Int J Environ Res Public Health. 2019;16(4):607. Published 2019 Feb 19. doi:10.3390/ijerph16040607

71. Keller J, Wolfensberger A, Clack L, et al. Do wearable alcohol-based handrub dispensers increase hand hygiene compliance? - a mixed-methods study. Antimicrob Resist Infect Control. 2018;7:143. Published 2018 Nov 23. doi:10.1186/s13756-018-0439-5

72. Woodard JA, Leekha S, Jackson SS, Thom KA. Beyond entry and exit: Hand hygiene at the bedside. Am J Infect Control. 2019;47(5):487-491. doi:10.1016/j.ajic.2018.10.026

73. C Soyemi et.al.Comparison of Patient and Healthcare Professional Perceptions of Hand Hygiene Practices with the Monthly Internal Audit at a Tertiary Medical Center. American Journal of Infection Control.2011;39(5)

74. Alemayehu $\mathrm{H}, \mathrm{Ho}$ V et al. Medical students and hospital hand hygiene - What do they know, and what do they do? P. Surg. Infect. 2011, 12: S1 
75. Kim, S., Cho, M., Kim, W. et al. P137: Effectiveness of a hand hygiene improvement program in doctors: active monitoring and real-time feedback. Antimicrob Resist Infect Control 2, P137 (2013). https://doi.org/10.1186/2047-2994-2-S1-P137

76. van Dalen R, Gombert K, Bhattacharya S, Datta SS. Mind the mind: results of a handhygiene research in a state-of-the-art cancer hospital. Indian J Med Microbiol. 2013;31(3):280-282. doi:10.4103/0255-0857.115639

77. O'Donoghue M, Ng SH, Suen LK, Boost M. A quasi-experimental study to determine the effects of a multifaceted educational intervention on hand hygiene compliance in a radiography unit. Antimicrob Resist Infect Control. 2016;5:36. Published 2016 Oct 19. doi:10.1186/s13756-016-0133-4

78. Galiani S, Gertler P, Ajzenman N, Orsola-Vidal A. Promoting Handwashing Behavior: The Effects of Large-scale Community and School-level Interventions. Health Econ. 2016;25(12):1545-1559. doi:10.1002/hec.3273

79. Lakshmi, V., Ghafur, A., Mageshkumar, K. et al. Knowledge and practice of infection control - in the NDM1 era. Antimicrob Resist Infect Control 4, P118 (2015). https://doi.org/10.1186/2047-2994-4-S1-P118

80. Kelcikova S, Mazuchova L, Bielena L, Filova L. Flawed self-assessment in hand hygiene: A major contributor to infections in clinical practice?. J Clin Nurs. 2019;28(11-12):22652275. doi:10.1111/jocn.14823

81. Davies R et.al 1The impact of "freedom day" on COVID-19 health protective behaviour in England: An observational study of hand hygiene, face covering use and physical distancing in public spaces pre and post the relaxing of restrictions. OSF. Available from: OSF I Manuscript observational study - preprint 19-10-2021.pdf

82. Davies R, Weinman J, Rubin GJ. Observed and self-reported COVID-19 health protection behaviours on a university campus and the impact of a single simple intervention. MedRXiv. Available from: https://www.medrxiv.org/content/10.1101/2021.06.15.21258920v1

83. (Kormos, C. \& Gifford, R. The validity of self - report measures of proenvironmental behavior: A meta - analytic review. J. Environ. Psychol. 2014. 40, 359 -371)

84. Smith, L. E., Potts, H., Amlôt, R., Fear, N. T., Michie, S., \& Rubin, G. J. (2021). Adherence to the test, trace, and isolate system in the UK: results from 37 nationally representative surveys. BMJ (Clinical research ed.), 372, n608. https://doi.org/10.1136/bmj.n608

85. www.ons.gov.uk. (2021). Coronavirus and self-isolation after testing positive in England - Office for National Statistics. [online] Available at:

https://www.ons.gov.uk/peoplepopulationandcommunity/healthandsocialcare/health andwellbeing/bulletins/coronavirusandselfisolationaftertestingpositiveinengland/27se ptemberto2october2021 [Accessed 19 Nov. 2021].

86. Mangtani, P., Shah, A., \& Roberts, J. A. (2007). Validation of influenza and pneumococcal vaccine status in adults based on self-report. Epidemiology and infection, 135(1), 139-143. https://doi.org/10.1017/\$0950268806006479

87. Rolnick, S. J., Parker, E. D., Nordin, J. D., Hedblom, B. D., Wei, F., Kerby, T., Jackson, J. M., Crain, A. L., \& Euler, G. (2013). Self-report compared to electronic medical record across eight adult vaccines: do results vary by demographic factors?. Vaccine, 31(37), 3928-3935. https://doi.org/10.1016/j.vaccine.2013.06.041 
medRxiv preprint doi: https://doi.org/10.1101/2021.12.22.21268226; this version posted December 23, 2021. The copyright holder for this preprint (which was not certified by peer review) is the author/funder, who has granted medRxiv a license to display the preprint in perpetuity.

It is made available under a CC-BY 4.0 International license.

88. Gupta, C et.al.Coronamask: A Face Mask Detector for Real-Time Data. International Journal of Advanced Trends in Computer Science and Engineering.2020;9. 5624-5630. 10.30534/ijatcse/2020/212942020.

89. Pouw CAS, Toschi F, van Schadewijk F, Corbetta A. Monitoring physical distancing for crowd management: Real-time trajectory and group analysis. PLoS One. 2020;29;15(10):e0240963. doi: 10.1371/journal.pone.0240963.

90. Cawthorne KR, Oliver C, Cooke RPD. A user's view of commercial mobile applications designed to measure hand hygiene compliance by direct observation [published online ahead of print, 2021 Aug 14]. J Hosp Infect. 2021;117:4-8.

doi:10.1016/j.jhin.2021.08.008 
medRxiv preprint doi: https://doi.org/10.1101/2021.12.22.21268226; this version posted December 23, 2021. The copyright holder for this preprint (which was not certified by peer review) is the author/funder, who has granted medRxiv a license to display the preprint in perpetuity.

It is made available under a CC-BY 4.0 International license .

\section{Supplementary Material}

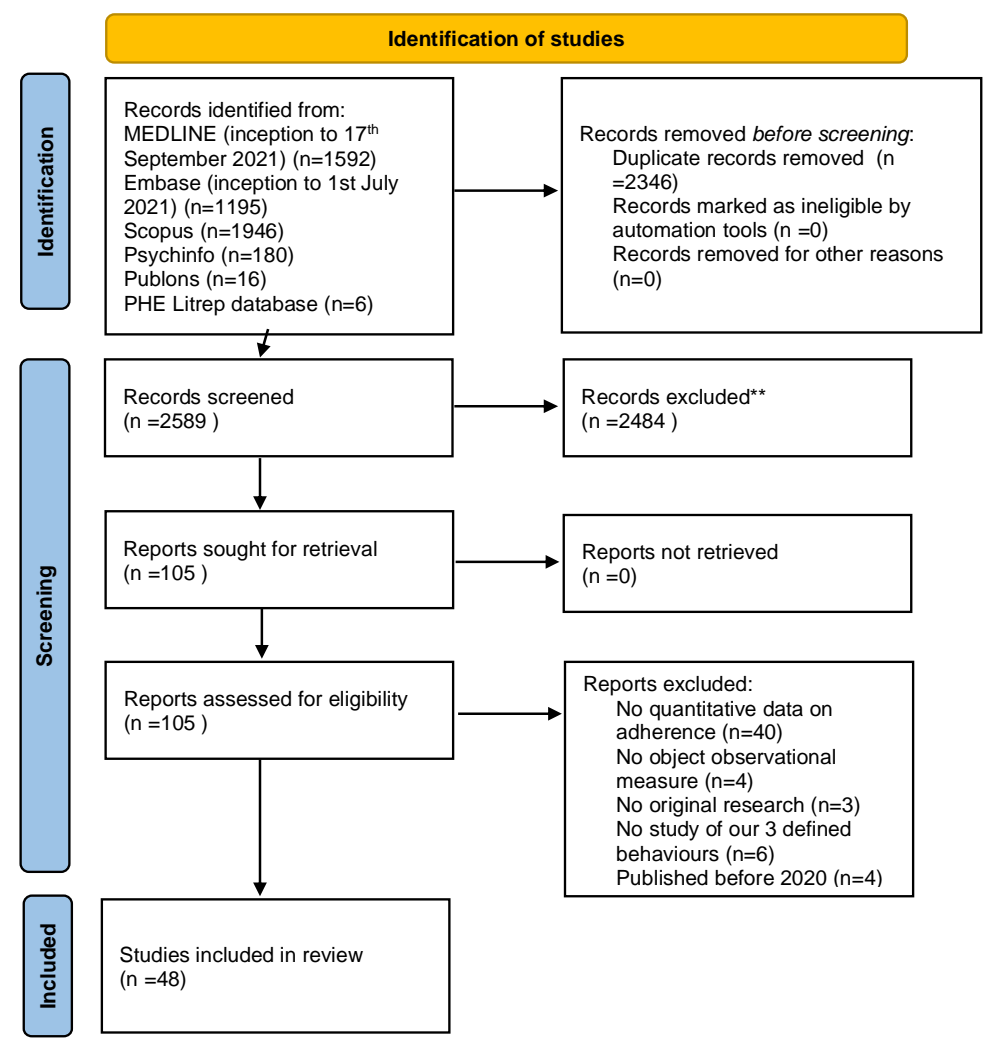

Figure 5: Flow chart for included studies aims one and two 
medRxiv preprint doi: https://doi.org/10.1101/2021.12.22.21268226; this version posted December 23, 2021. The copyright holder for this preprint (which was not certified by peer review) is the author/funder, who has granted medRxiv a license to display the preprint in perpetuity.

It is made available under a CC-BY 4.0 International license.

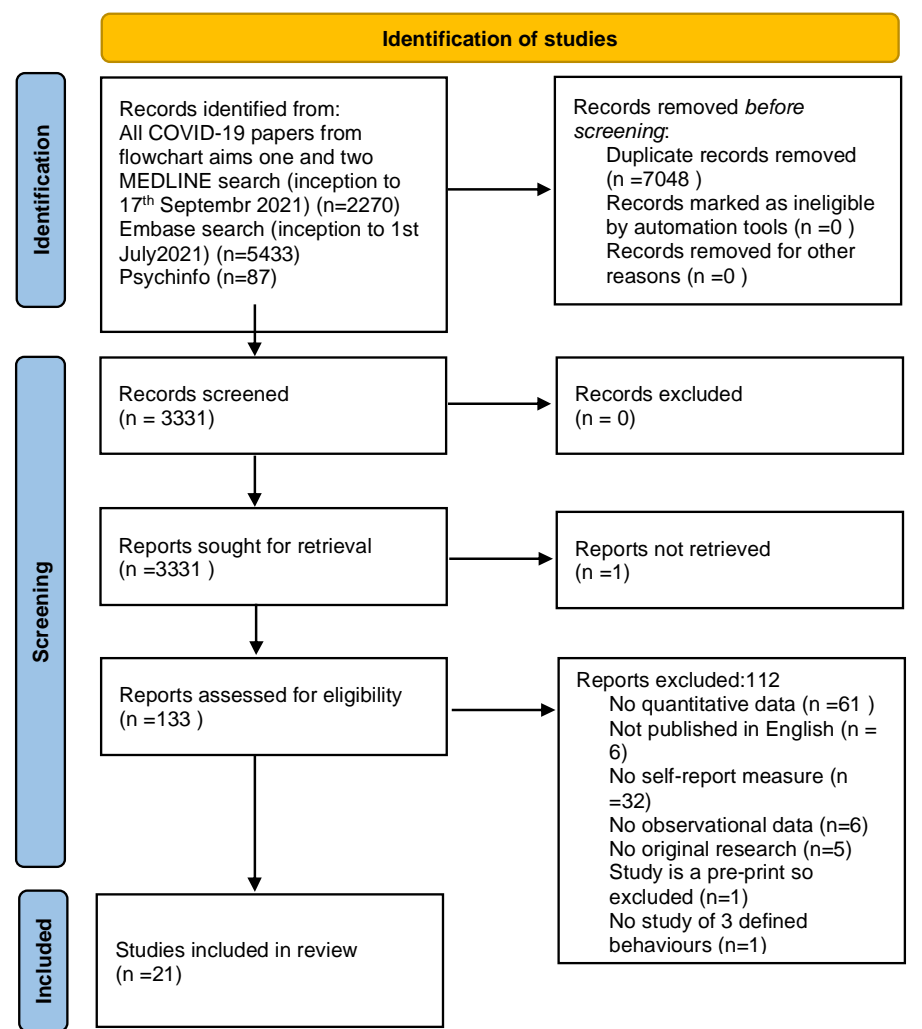

Figure 6: Flowchart for included studies aim three 
Table 2: Characteristics of included studies aims one and two (COVID-19 papers)

\begin{tabular}{|c|c|c|c|c|c|c|c|c|c|c|c|c|}
\hline & $\begin{array}{l}\text { Date of } \\
\text { observati } \\
\text { ons }\end{array}$ & $\begin{array}{l}\text { Date of } \\
\text { publicatio } \\
\text { n }\end{array}$ & $\begin{array}{l}\text { Interven } \\
\text { tion } \\
\text { compon } \\
\text { ent }\end{array}$ & $\begin{array}{l}\text { Study } \\
\text { design }\end{array}$ & $\begin{array}{l}\text { Number of } \\
\text { events }\end{array}$ & $\begin{array}{l}\text { Sample } \\
\text { size }\end{array}$ & $\begin{array}{l}\text { Hand } \\
\text { hygien } \\
\text { e } \\
\text { adhere } \\
\text { nce \% }\end{array}$ & $\begin{array}{l}\text { Face } \\
\text { covering } \\
\text { adherence } \\
\%\end{array}$ & $\begin{array}{l}\text { Social } \\
\text { distance } \\
\text { adherence } \\
\%\end{array}$ & $\begin{array}{l}\text { Where } \\
\text { did } \\
\text { observa } \\
\text { tions } \\
\text { take } \\
\text { place }\end{array}$ & $\begin{array}{l}\text { Population } \\
\text { observed }\end{array}$ & $\begin{array}{l}\text { Other } \\
\text { location } \\
\text { data }\end{array}$ \\
\hline 1 & $\begin{array}{l}\text { 1 Jan } \\
2015-31 \\
\text { Dec } 2020\end{array}$ & Apr-21 & no & $\begin{array}{l}\text { direct } \\
\text { observer }\end{array}$ & 13494 & 13494 & $66 \%$ & $\mathrm{n} / \mathrm{a}$ & $\mathrm{n} / \mathrm{a}$ & hospital & $\begin{array}{l}\text { healthcare } \\
\text { workers }\end{array}$ & Sicily, Italy \\
\hline 2 & $\begin{array}{l}22 \text { Apr-9 } \\
\text { May } 2020\end{array}$ & $\begin{array}{r}\text { 13-Aug- } \\
20\end{array}$ & no & $\begin{array}{l}\text { direct } \\
\text { observer }\end{array}$ & 1000 & 1000 & $\mathrm{n} / \mathrm{a}$ & $57 \%$ & $\mathrm{n} / \mathrm{a}$ & $\begin{array}{l}\text { public } \\
\text { parks, } \\
\text { banks, } \\
\text { outpatie } \\
\text { nt } \\
\text { clinics, } \\
\text { bus } \\
\text { stations }\end{array}$ & $\begin{array}{l}\text { general } \\
\text { population }\end{array}$ & Iran \\
\hline 3 & $\begin{array}{l}\text { not } \\
\text { reported }\end{array}$ & 02-Jun-20 & no & $\begin{array}{l}\text { direct } \\
\text { observer }\end{array}$ & 382 & 382 & $\mathrm{n} / \mathrm{a}$ & $64.1 \%$ & $\mathrm{n} / \mathrm{a}$ & hospital & $\begin{array}{l}\text { healthcare } \\
\text { workers and } \\
\text { hospital } \\
\text { staff }\end{array}$ & India \\
\hline 4 & $\begin{array}{l}\text { 5-8 Apr } \\
2020\end{array}$ & 09-Jul-20 & no & $\begin{array}{l}\text { direct } \\
\text { observer }\end{array}$ & 78 & 78 & $\mathrm{n} / \mathrm{a}$ & $32 \%$ & $\mathrm{n} / \mathrm{a}$ & $\begin{array}{l}\text { food } \\
\text { stores }\end{array}$ & $\begin{array}{l}\text { general } \\
\text { population }\end{array}$ & $\begin{array}{l}\text { Braga, } \\
\text { Portugal }\end{array}$ \\
\hline 5 & $\begin{array}{l}\text { May-Jun } \\
2020\end{array}$ & $\begin{array}{r}\text { 18-May- } \\
21\end{array}$ & no & $\begin{array}{l}\text { video } \\
\text { observati } \\
\text { on }\end{array}$ & 383 & 383 & $\mathrm{n} / \mathrm{a}$ & $43 \%$ & $\mathrm{n} / \mathrm{a}$ & $\begin{array}{l}\text { public } \\
\text { streets }\end{array}$ & $\begin{array}{l}\text { general } \\
\text { population }\end{array}$ & $\begin{array}{l}\text { Amsterdam } \\
\text { Netherlands }\end{array}$ \\
\hline 6 & $\begin{array}{l}\text { 5-8 Apr } \\
\text { 20; 18-27 } \\
\text { Apr 20; } \\
\text { 18-27 Jun } \\
2020\end{array}$ & Feb-21 & no & $\begin{array}{l}\text { direct } \\
\text { observer }\end{array}$ & 238 & 238 & $\mathrm{n} / \mathrm{a}$ & $\begin{array}{l}96.6 \% \\
\text { men, } 100 \% \\
\text { women }\end{array}$ & $\mathrm{n} / \mathrm{a}$ & $\begin{array}{l}\text { food } \\
\text { stores }\end{array}$ & $\begin{array}{l}\text { general } \\
\text { population }\end{array}$ & $\begin{array}{l}\text { Braga, } \\
\text { Portugal }\end{array}$ \\
\hline 7 & $\begin{array}{l}1-29 \mathrm{Feb} \\
2020\end{array}$ & 25-Mar-21 & no & $\begin{array}{l}\text { direct } \\
\text { observer }\end{array}$ & 10211 & 10211 & $\mathrm{n} / \mathrm{a}$ & $82.5 \%$ & $\mathrm{n} / \mathrm{a}$ & $\begin{array}{l}\text { public } \\
\text { streets }\end{array}$ & $\begin{array}{l}\text { general } \\
\text { population }\end{array}$ & Hong Kong \\
\hline 8 & $\begin{array}{l}10,18,25 \\
\text { May } 2020\end{array}$ & $23-F e b-21$ & no & $\begin{array}{l}\text { direct } \\
\text { observer }\end{array}$ & 3965 & 2353 & $\mathrm{n} / \mathrm{a}$ & $\begin{array}{l}73.6 \% \text { at } \\
\text { time } 1 ; \\
66.5 \% \text { at } \\
\text { time } 2 ;\end{array}$ & $\mathrm{n} / \mathrm{a}$ & $\begin{array}{l}\text { public } \\
\text { streets, } \\
\text { parks, } \\
\text { enclosed }\end{array}$ & $\begin{array}{l}\text { general } \\
\text { population }\end{array}$ & Poland \\
\hline
\end{tabular}




\begin{tabular}{|c|c|c|c|c|c|c|c|c|c|c|c|c|}
\hline & & & & & & & & $\begin{array}{l}65.7 \% \text { at } \\
\text { time } 3 ; \\
\text { highest } \\
\text { while } \\
\text { shopping } \\
(84.9 \% \text {; } \\
81.7 \text { and } \\
80.3 \%) \\
\text { and the } \\
\text { lowest } \\
\text { during } \\
\text { outdoor } \\
\text { sport } \\
\text { activity } \\
(63 \% \text {; } \\
53.5 \text { and } \\
48.7 \%) \text {. }\end{array}$ & & $\begin{array}{l}\text { shoppin } \\
\mathrm{g} \\
\text { centres }\end{array}$ & & \\
\hline 9 & $\begin{array}{l}\text { Sep-Nov } \\
2020\end{array}$ & $05-F e b-21$ & no & $\begin{array}{l}\text { direct } \\
\text { observer }\end{array}$ & 17200 & 17200 & $\mathrm{n} / \mathrm{a}$ & $76.70 \%$ & $\mathrm{n} / \mathrm{a}$ & $\begin{array}{l}\text { universit } \\
\text { ies }\end{array}$ & $\begin{array}{l}\text { staff and } \\
\text { students }\end{array}$ & $\begin{array}{l}\text { rural and } \\
\text { urban } \\
\text { universities } \\
\text { across USA }\end{array}$ \\
\hline 10 & $\begin{array}{l}20 \mathrm{Jul} \\
2020 \text { for } 4 \\
\text { weeks; } 21 \\
\text { Sep } 2020 \\
\text { for } 14 \\
\text { weeks }\end{array}$ & $\begin{array}{r}\text { 03-May- } \\
21\end{array}$ & yes & $\begin{array}{l}\text { direct } \\
\text { observer }\end{array}$ & 4122 & 4122 & $\mathrm{n} / \mathrm{a}$ & $\begin{array}{l}82.2 \% \text { pre } \\
\text { interventio } \\
\mathrm{n} ; 92.2 \% \\
\text { wore after } \\
\text { interventio } \\
\mathrm{n}\end{array}$ & $\mathrm{n} / \mathrm{a}$ & hospitals & $\begin{array}{l}\text { healthcare } \\
\text { workers }\end{array}$ & $\begin{array}{l}\text { Connecticut } \\
\text {, USA }\end{array}$ \\
\hline 11 & $\begin{array}{l}\text { Jul-Aug } \\
2020 ; 23- \\
30 \text { Nov } \\
2020 ; 1-5 \\
\text { Dec } 2020\end{array}$ & 18-Apr-21 & yes & $\begin{array}{l}\text { direct } \\
\text { observer }\end{array}$ & 219 & 219 & $\begin{array}{l}35.2 \% \\
40 \% \\
\text { healthc } \\
\text { are } \\
\text { worker } \\
\text { s }\end{array}$ & $\begin{array}{l}100 \% \text { of } \\
\text { public and } \\
\text { healthcare } \\
\text { workers }\end{array}$ & $\mathrm{n} / \mathrm{a}$ & hospitals & $\begin{array}{l}\text { patients and } \\
\text { healthcare } \\
\text { workers }\end{array}$ & $\begin{array}{l}\text { Bangkok, } \\
\text { Thailand }\end{array}$ \\
\hline 12 & May-20 & 01-Sep-20 & no & $\begin{array}{l}\text { direct } \\
\text { observer }\end{array}$ & 271 & 271 & $\mathrm{n} / \mathrm{a}$ & $\begin{array}{l}94.2 \% \\
\text { overall. } \\
100 \% \text { on } \\
\text { COVID- } \\
19- \\
\text { designated }\end{array}$ & $\mathrm{n} / \mathrm{a}$ & hospital & $\begin{array}{l}\text { healthcare } \\
\text { workers }\end{array}$ & UK \\
\hline
\end{tabular}




\begin{tabular}{|c|c|c|c|c|c|c|c|c|c|c|c|c|}
\hline & & & & & & & & $\begin{array}{l}\text { wards and } \\
48 \% \text { on } \\
\text { non- } \\
\text { COVID- } \\
19 \text { wards }\end{array}$ & & & & \\
\hline 13 & $\begin{array}{l}\text { 3-9 Jun } \\
\text { 2020; } 24 \\
\text { Jul-3 Aug } \\
2020\end{array}$ & 15 -Oct-20 & no & $\begin{array}{l}\text { direct } \\
\text { observer }\end{array}$ & 9935 & 9935 & $\mathrm{n} / \mathrm{a}$ & $41.5 \%$ & $\mathrm{n} / \mathrm{a}$ & $\begin{array}{l}\text { retail } \\
\text { stores }\end{array}$ & $\begin{array}{l}\text { general } \\
\text { population }\end{array}$ & $\begin{array}{l}\text { rural and } \\
\text { urban } \\
\text { Wisconsin, } \\
\text { USA }\end{array}$ \\
\hline 14 & $\begin{array}{l}16-30 \\
\text { May } 2020\end{array}$ & 13-Apr-21 & no & $\begin{array}{l}\text { direct } \\
\text { observer }\end{array}$ & 1004 & 1004 & $\mathrm{n} / \mathrm{a}$ & $75.5 \%$ & $\mathrm{n} / \mathrm{a}$ & $\begin{array}{l}\text { public } \\
\text { business } \\
\text { es }\end{array}$ & $\begin{array}{l}\text { general } \\
\text { population }\end{array}$ & $\begin{array}{l}\text { Vermont, } \\
\text { USA }\end{array}$ \\
\hline 15 & $\begin{array}{l}\text { 5-8 May } \\
2020\end{array}$ & $\begin{array}{r}\text { 03-Aug- } \\
20\end{array}$ & no & $\begin{array}{l}\text { direct } \\
\text { observer }\end{array}$ & $\begin{array}{l}892 \text { face } \\
\text { cover } \\
\text { wearing, } 871 \\
\text { social } \\
\text { distancing }\end{array}$ & 1641 & $\mathrm{n} / \mathrm{a}$ & $12.6 \%$ & $\begin{array}{l}98 \% \\
\text { adherence }\end{array}$ & vehicles & $\begin{array}{l}\text { drivers and } \\
\text { passengers }\end{array}$ & Ghana \\
\hline 16 & $\begin{array}{l}30 \text { Mar-12 } \\
\text { Apr } 2020\end{array}$ & Sep-20 & no & $\begin{array}{l}\text { direct } \\
\text { observer }\end{array}$ & 3322 & 3322 & $\mathrm{n} / \mathrm{a}$ & $\begin{array}{l}98.2 \% \\
\text { wore face } \\
\text { cover; } \\
92.3 \% \\
\text { wore face } \\
\text { cover } \\
\text { correctly }\end{array}$ & $\mathrm{n} / \mathrm{a}$ & $\begin{array}{l}\text { market, } \\
\text { hospital }\end{array}$ & $\begin{array}{l}\text { general } \\
\text { population }\end{array}$ & Malaysia \\
\hline 17 & $\begin{array}{l}\text { 12 days } \\
\text { 9am-8pm } \\
\text { during } \\
\text { 'phase 2' } \\
\text { in Italy }\end{array}$ & 01-Jan-21 & no & $\begin{array}{l}\text { direct } \\
\text { observer }\end{array}$ & 1036 & 1036 & $\mathrm{n} / \mathrm{a}$ & $25.5 \%$ & $\mathrm{n} / \mathrm{a}$ & $\begin{array}{l}\text { in the } \\
\text { street', } \\
\text { most } \\
\text { people } \\
\text { observe } \\
\text { d were } \\
\text { outside } \\
\text { shops, } \\
\text { waiting } \\
\text { to enter }\end{array}$ & $\begin{array}{l}\text { general } \\
\text { population } \\
\text { (excluded } \\
\text { children and } \\
\text { 'people with } \\
\text { special } \\
\text { needs' }\end{array}$ & Italy \\
\hline 18 & $\begin{array}{l}11 \mathrm{am} \text { to } \\
1 \mathrm{pm} \mathrm{6-9} \\
\text { Aug } 2020\end{array}$ & $\begin{array}{r}\text { 17-Nov- } \\
20\end{array}$ & yes & $\begin{array}{l}\text { video } \\
\text { observati } \\
\text { on quasi } \\
\text { experime } \\
\text { nt; }\end{array}$ & 1286 & 400 & $\mathrm{n} / \mathrm{a}$ & $\mathrm{n} / \mathrm{a}$ & $20 \%$ & $\begin{array}{l}\text { a } \\
\text { universit } \\
\mathrm{y} \\
\text { canteen }\end{array}$ & $\begin{array}{l}\text { university } \\
\text { canteen } \\
\text { customers }\end{array}$ & Thailand \\
\hline
\end{tabular}




\begin{tabular}{|c|c|c|c|c|c|c|c|c|c|c|c|c|}
\hline & & & & $\begin{array}{l}\text { comparati } \\
\text { ve } \\
\text { behaviour } \\
\text { al } \\
\text { observati } \\
\text { on }\end{array}$ & & & & & & & & \\
\hline 19 & $\begin{array}{l}\text { 4-25 May } \\
2020\end{array}$ & $\begin{array}{r}\text { 03-May- } \\
21\end{array}$ & no & $\begin{array}{l}\text { direct } \\
\text { observer }\end{array}$ & 182 & 182 & $\mathrm{n} / \mathrm{a}$ & $94 \%$ & $\mathrm{n} / \mathrm{a}$ & $\begin{array}{l}\text { on } \\
\text { public } \\
\text { transport } \\
\text { (subway } \\
\text { and } \\
\text { local } \\
\text { trains) }\end{array}$ & $\begin{array}{l}\text { public } \\
\text { transportatio } \\
\text { n users }\end{array}$ & $\begin{array}{l}\text { Paris, } \\
\text { France }\end{array}$ \\
\hline 20 & $\begin{array}{l}21 \text { Sep } \\
2020 \text { to } 2 \\
\text { Oct } 2020\end{array}$ & $24-$ Oct-20 & no & $\begin{array}{l}\text { direct } \\
\text { observer }\end{array}$ & 187 & 187 & $\mathrm{n} / \mathrm{a}$ & $\begin{array}{l}80.1 \% \text { at } \\
\text { perimeter, } \\
93.4 \% \text { by } \\
\text { entry }\end{array}$ & $\mathrm{n} / \mathrm{a}$ & $\begin{array}{l}\text { general } \\
\text { ob/gyn } \\
\text { outpatie } \\
\text { nt clinic }\end{array}$ & $\begin{array}{l}\text { patients and } \\
\text { visitors }\end{array}$ & $\begin{array}{l}\text { North } \\
\text { Carolina, } \\
\text { USA }\end{array}$ \\
\hline 21 & $\begin{array}{l}\text { 15-18 Jun } \\
\text { 2020; 20- } \\
\text { 21 Jun } \\
\text { 2020; 22- } \\
\text { 24 Jun } \\
2020\end{array}$ & 14-Oct-20 & yes & $\begin{array}{l}\text { direct } \\
\text { observer- } \\
\text { quasi } \\
\text { experime } \\
\text { nt; } \\
\text { comparati } \\
\text { ve } \\
\text { behaviour } \\
\text { al } \\
\text { observati } \\
\text { on }\end{array}$ & 466 & 466 & $\begin{array}{l}0 \% \\
\text { adhere } \\
\text { nce pre } \\
\text { interve } \\
\text { ntion; } \\
12 \% \\
\text { adhere } \\
\text { nce } \\
\text { post } \\
\text { interve } \\
\text { ntion }\end{array}$ & $\mathrm{n} / \mathrm{a}$ & $\mathrm{n} / \mathrm{a}$ & hospital & $\begin{array}{l}\text { outpatients } \\
\text { and visitors }\end{array}$ & Thailand \\
\hline 22 & $\begin{array}{l}\text { 2-11 Aug } \\
2020\end{array}$ & 14-Jan-21 & no & $\begin{array}{l}\text { direct } \\
\text { observer }\end{array}$ & 10440 & 10440 & $\mathrm{n} / \mathrm{a}$ & $\begin{array}{l}45.6 \% \\
\text { wore face } \\
\text { cover; } \\
75.6 \% \text { of } \\
\text { face } \\
\text { covering } \\
\text { wearers } \\
\text { wore it } \\
\text { correctly }\end{array}$ & $\mathrm{n} / \mathrm{a}$ & $\begin{array}{l}\text { in the } \\
\text { street }\end{array}$ & $\begin{array}{l}\text { general } \\
\text { population }\end{array}$ & $\begin{array}{l}8 \text { urban } \\
\text { districts, } 92 \\
\text { neighbourh } \\
\text { oods of } \\
\text { Ahvaz, Iran }\end{array}$ \\
\hline 23 & $\begin{array}{l}\text { Jan 2018- } \\
\text { October }\end{array}$ & 29-Jul-20 & no & $\begin{array}{l}\text { video } \\
\text { observati }\end{array}$ & 7586 & 7586 & $\mathrm{n} / \mathrm{a}$ & $\begin{array}{l}\text { face cover } \\
\text { wearing }\end{array}$ & $\mathrm{n} / \mathrm{a}$ & $\begin{array}{l}\text { public } \\
\text { transport }\end{array}$ & $\begin{array}{l}\text { general } \\
\text { population }\end{array}$ & $\begin{array}{l}\text { China, } \\
\text { Japan, }\end{array}$ \\
\hline
\end{tabular}




\begin{tabular}{|c|c|c|c|c|c|c|c|c|c|c|c|c|}
\hline & $\begin{array}{l}2019 ; \\
\text { Feb-Mar } \\
2020\end{array}$ & & & on & & & & $\begin{array}{l}\text { increased } \\
\text { in all } \\
\text { regions } \\
\text { except the } \\
\text { US, from } \\
(1.1 \%) \text { to } \\
(99.4 \%) \text { in } \\
\text { mainland } \\
\text { China. }(3.1 \\
\%) \text { to } \\
(38.7 \%) \text { in } \\
\text { Japan } \\
(0.8 \%) \text { to } \\
(85.5 \%) \\
\text { in South } \\
\text { Korea. } \\
(0.2 \%) \text { to } \\
(1.6 \%) \text { in } \\
\text { Western } \\
\text { Europe } \\
\text { and } \\
(0.4 \%) \text { to } \\
(2.1 \%) \text { in } \\
\text { the US }\end{array}$ & & $\begin{array}{l}\text { ation } \\
\text { stations, } \\
\text { streets, } \\
\text { parks }\end{array}$ & & $\begin{array}{l}\text { South } \\
\text { Korea, US, } \\
\text { England, } \\
\text { France, } \\
\text { Germany, } \\
\text { Spain, Italy }\end{array}$ \\
\hline 24 & $\begin{array}{l}\text { 5-7 Mar } \\
2020\end{array}$ & 06-Jun-20 & no & $\begin{array}{l}\text { direct } \\
\text { observer }\end{array}$ & 1761 & $\mathrm{n} / \mathrm{a}$ & $79.44 \%$ & $\mathrm{n} / \mathrm{a}$ & $\mathrm{n} / \mathrm{a}$ & hospital & $\begin{array}{l}\text { healthcare } \\
\text { workers }\end{array}$ & $\begin{array}{l}\text { Tongji, } \\
\text { China }\end{array}$ \\
\hline 25 & $\begin{array}{l}27 \mathrm{Feb}-21 \\
\text { Apr } 2020\end{array}$ & 10-Dec-20 & no & $\begin{array}{l}\text { direct } \\
\text { observer }\end{array}$ & 610 & 127 & $\begin{array}{l}82 \% \\
\text { adhere } \\
\text { nce in } \\
\text { COVI } \\
\text { D- } \\
\text { 19ward } \\
\text { vs } 65 \% \\
\text { non- } \\
\text { COVI } \\
\text { D-19 } \\
\text { ward }\end{array}$ & $\mathrm{n} / \mathrm{a}$ & $\mathrm{n} / \mathrm{a}$ & $\begin{array}{l}\text { hospital } \\
\text { pulmono } \\
\text { logy } \\
\text { departm } \\
\text { ent }\end{array}$ & $\begin{array}{l}\text { healthcare } \\
\text { workers }\end{array}$ & $\begin{array}{l}\text { Cologne, } \\
\text { Germany }\end{array}$ \\
\hline 26 & $\begin{array}{l}21-30 \mathrm{Apr} \\
2020\end{array}$ & 26-Oct-20 & no & $\begin{array}{l}\text { direct } \\
\text { observer }\end{array}$ & 468 & 468 & $\mathrm{n} / \mathrm{a}$ & $\begin{array}{l}85.42 \% \\
\text { wore face }\end{array}$ & $\mathrm{n} / \mathrm{a}$ & $\begin{array}{l}\text { street, } \\
\text { public }\end{array}$ & $\begin{array}{l}\text { general } \\
\text { population }\end{array}$ & $\begin{array}{l}\text { Basseterre, } \\
\text { St. Kitts }\end{array}$ \\
\hline
\end{tabular}




\begin{tabular}{|c|c|c|c|c|c|c|c|c|c|c|c|c|}
\hline & & & & & & & & $\begin{array}{l}\text { covering; } \\
66 \% \text { wore } \\
\text { face } \\
\text { covering } \\
\text { correctly; }\end{array}$ & & $\begin{array}{l}\text { transport } \\
\text { ation, } \\
\text { grocery } \\
\text { store } \\
\text { line }\end{array}$ & & \\
\hline 27 & $\begin{array}{l}\text { Jul-Aug } \\
2020\end{array}$ & 12-Mar-21 & no & $\begin{array}{l}\text { direct } \\
\text { observer }\end{array}$ & 422 & 422 & $\mathrm{n} / \mathrm{a}$ & $54.68 \%$ & $\mathrm{n} / \mathrm{a}$ & $\begin{array}{l}\operatorname{taxi} \\
\text { stands }\end{array}$ & taxi drivers & $\begin{array}{l}\text { Dessie City } \\
\text { and } \\
\text { Kombolcha } \\
\text { Towns, } \\
\text { Ethiopia }\end{array}$ \\
\hline 28 & $\begin{array}{l}20-24 \mathrm{Jul} \\
2020\end{array}$ & 28-Dec-20 & no & $\begin{array}{l}\text { direct } \\
\text { observer }\end{array}$ & 2302 & 2286 & $\mathrm{n} / \mathrm{a}$ & $98 \%$ & $\mathrm{n} / \mathrm{a}$ & $\begin{array}{l}\text { ophthal } \\
\text { mology } \\
\text { outpatie } \\
\text { nt } \\
\text { clinics }\end{array}$ & patients & $\begin{array}{l}\text { Pennsylvan } \\
\text { ia, USA }\end{array}$ \\
\hline 29 & $\begin{array}{l}\text { Apr-Jun } \\
2020\end{array}$ & $\begin{array}{r}\text { 03-May- } \\
21\end{array}$ & no & $\begin{array}{l}\text { direct } \\
\text { observer }\end{array}$ & 2080 & 2080 & $\mathrm{n} / \mathrm{a}$ & $65 \%$ & $\mathrm{n} / \mathrm{a}$ & $\begin{array}{l}\text { outside } \\
\text { grocery } \\
\text { stores }\end{array}$ & $\begin{array}{l}\text { general } \\
\text { population }\end{array}$ & $\begin{array}{l}\text { Western } \\
\text { Australia }\end{array}$ \\
\hline 30 & Jul-20 & 05-Jan-21 & no & $\begin{array}{l}\text { direct } \\
\text { observer }\end{array}$ & 1096 & 1096 & $\mathrm{n} / \mathrm{a}$ & $\begin{array}{l}70.2 \% \text { at } \\
\text { mosque; } \\
68.7 \% \text { in } \\
\text { malls; } \\
32.6 \% \text { in } \\
\text { park; } \\
45.2 \% \text { in } \\
\text { barbersho } \\
\text { p }\end{array}$ & $\mathrm{n} / \mathrm{a}$ & $\begin{array}{l}\text { in the } \\
\text { commun } \\
\text { ity } \\
\text { (mosque } \\
\text { s, malls, } \\
\text { parks, } \\
\text { barbersh } \\
\text { ops) }\end{array}$ & $\begin{array}{l}\text { general } \\
\text { population }\end{array}$ & $\begin{array}{l}\text { cities in } \\
\text { Jazan } \\
\text { region of } \\
\text { Saudi } \\
\text { Arabia }\end{array}$ \\
\hline 31 & 30-Jul-20 & 01-Sep-20 & no & $\begin{array}{l}\text { direct } \\
\text { observer }\end{array}$ & 200 & 100 & $\mathrm{n} / \mathrm{a}$ & $77 \%$ & $\mathrm{n} / \mathrm{a}$ & $\begin{array}{l}\text { outdoor } \\
\text { street } \\
\text { location } \\
\text { s }\end{array}$ & $\begin{array}{l}\text { general } \\
\text { population }\end{array}$ & $\begin{array}{l}\text { Waikiki and } \\
\text { Honolulu, } \\
\text { Hawaii, } \\
\text { USA }\end{array}$ \\
\hline 32 & Jun-20 & $\begin{array}{r}\text { 18-Nov- } \\
20\end{array}$ & no & $\begin{array}{l}\text { direct } \\
\text { observer }\end{array}$ & 431 & 431 & $\begin{array}{l}57.46 \% \\
\text { adhere } \\
\text { nce on } \\
\text { subway } \\
44.78 \% \\
\text { adhere } \\
\text { nce } \\
\text { when }\end{array}$ & $\begin{array}{l}78.35 \% \text { on } \\
\text { subway; } \\
46.01 \% \\
\text { when } \\
\text { shopping }\end{array}$ & $\mathrm{n} / \mathrm{a}$ & $\begin{array}{l}\text { subway } \\
\text { station } \\
\text { and a } \\
\text { shop }\end{array}$ & $\begin{array}{l}\text { general } \\
\text { population }\end{array}$ & Tehran, Iran \\
\hline
\end{tabular}




\begin{tabular}{|c|c|c|c|c|c|c|c|c|c|c|c|c|}
\hline & & & & & & & $\begin{array}{l}\text { shoppi } \\
\text { ng }\end{array}$ & & & & & \\
\hline 33 & $\begin{array}{l}25 \text { Jun-21 } \\
\text { Jul } 2020\end{array}$ & 29-Mar-21 & no & $\begin{array}{l}\text { direct } \\
\text { observer }\end{array}$ & 3354 & 3354 & $\mathrm{n} / \mathrm{a}$ & $\begin{array}{l}56.4 \% \\
\text { wore face } \\
\text { coverings; } \\
75.2 \% \text { of } \\
\text { face } \\
\text { coverings } \\
\text { were worn } \\
\text { correctly }\end{array}$ & $\mathrm{n} / \mathrm{a}$ & $\begin{array}{l}\text { inside } \\
\text { shoppin } \\
\mathrm{g} \\
\text { centres } \\
\text { and train } \\
\text { stations; } \\
\text { outside } \\
\text { shoppin } \\
\mathrm{g} \\
\text { centres }\end{array}$ & $\begin{array}{l}\text { general } \\
\text { population }\end{array}$ & $\begin{array}{l}13 \text { cities in } \\
\text { Pays de la } \\
\text { Loire, } \\
\text { France }\end{array}$ \\
\hline 34 & $\begin{array}{l}4 \text { May-11 } \\
\text { Jun } 2020\end{array}$ & 25-Jan-21 & no & $\begin{array}{l}\text { direct } \\
\text { observer }\end{array}$ & 3061 & 3061 & $2 \%$ & $\begin{array}{l}96 \% \\
\text { smokers } \\
\text { possessed } \\
\text { a face } \\
\text { covering. } \\
\text { While } \\
\text { smoking, } \\
0.2 \% \text { wore } \\
\text { there face } \\
\text { covering } \\
\text { fully, } \\
81.6 \% \text { of } \\
\text { smokers } \\
\text { put the } \\
\text { face cover } \\
\text { under the } \\
\text { chin and } \\
13.8 \% \\
\text { carried it } \\
\text { in the } \\
\text { hand, } \\
32.4 \% \text { did } \\
\text { not wear a } \\
\text { face } \\
\text { covering } \\
\text { immediate } \\
\text { ly after }\end{array}$ & $25.7 \%$ & $\begin{array}{l}\text { outdoor } \\
\text { street } \\
\text { location } \\
\mathrm{s}\end{array}$ & $\begin{array}{l}\text { general } \\
\text { population }\end{array}$ & Hong Kong \\
\hline
\end{tabular}




\begin{tabular}{|c|c|c|c|c|c|c|c|c|c|c|c|c|}
\hline & & & & & & & & smoking. & & & & \\
\hline 35 & Jul-20 & 24-Jan-21 & no & $\begin{array}{l}\text { mixed } \\
\text { methods. } \\
\text { direct } \\
\text { observer/ } \\
\text { media }\end{array}$ & 1152 & $\begin{array}{l}1152 \\
\text { people }\end{array}$ & $\mathrm{n} / \mathrm{a}$ & $70 \%$ & 0 & $\begin{array}{l}\text { in } \\
\text { person } \\
\text { high } \\
\text { school } \\
\text { graduati } \\
\text { on }\end{array}$ & $\begin{array}{l}\text { high school } \\
\text { students }\end{array}$ & USA \\
\hline 36 & $\begin{array}{l}\text { unstated, } \\
\text { during } \\
\text { COVID- } \\
19\end{array}$ & Dec-20 & no & $\begin{array}{l}\text { video } \\
\text { observati } \\
\text { on }\end{array}$ & 1594 & 1594 & $\mathrm{n} / \mathrm{a}$ & $\mathrm{n} / \mathrm{a}$ & $\begin{array}{l}40.4 \% \\
\text { Oxford } \\
\text { Town } \\
\text { Centre } \\
\text { dataset; } \\
17.6 \% \text { in } \\
\text { the Mall } \\
\text { dataset; } \\
\text { and, } \\
58.1 \% \\
\text { CUHK } \\
\text { Square } \\
\text { dataset }\end{array}$ & $\begin{array}{l}\text { oxford } \\
\text { town } \\
\text { centre }\end{array}$ & $\begin{array}{l}\text { all general } \\
\text { public any } \\
\text { age }\end{array}$ & $\begin{array}{l}\text { city } \\
\text { centre/shop } \\
\text { ping mall } \\
\text { UK }\end{array}$ \\
\hline 37 & $\begin{array}{l}2 \text { January } \\
\text { to } 15 \\
\text { March } \\
2020\end{array}$ & Oct-21 & no & $\begin{array}{l}\text { direct } \\
\text { observer }\end{array}$ & 267 & unknown & $\begin{array}{l}47 \text { per } \\
\text { cent } \\
\text { pre- } \\
\text { COVI } \\
\text { D-19 } \\
\text { pande } \\
\text { mic to } \\
95 \text { per } \\
\text { cent } \\
\text { just } \\
\text { before } \\
\text { lockdo } \\
\text { wn }\end{array}$ & $\mathrm{n} / \mathrm{a}$ & $\mathrm{n} / \mathrm{a}$ & $\begin{array}{l}\text { obstetric } \\
\text { ward }\end{array}$ & $\begin{array}{l}\text { healthcare } \\
\text { worker }\end{array}$ & Germany \\
\hline 38 & unknown & Dec-20 & no & $\begin{array}{l}\text { direct } \\
\text { observer } \\
\text { and } \\
\text { survey }\end{array}$ & 400 & $\begin{array}{l}400 \\
\text { people }\end{array}$ & $45.6 \%$ & $\mathrm{n} / \mathrm{a}$ & $\mathrm{n} / \mathrm{a}$ & $\begin{array}{l}\text { home } \\
\text { health } \\
\text { care }\end{array}$ & nurses & USA \\
\hline 39 & $\begin{array}{l}\text { June } 1 \text {, } \\
2020 \text {, to }\end{array}$ & Oct-20 & yes & $\begin{array}{l}\text { direct } \\
\text { observer }\end{array}$ & 42 & $\begin{array}{l}42 \\
\text { people }\end{array}$ & $33.59 \%$ & $\mathrm{n} / \mathrm{a}$ & $\mathrm{n} / \mathrm{a}$ & $\begin{array}{l}\text { tertiary } \\
\text { care }\end{array}$ & $\begin{array}{l}\text { surgical } \\
\text { trainees }\end{array}$ & Calcutta \\
\hline
\end{tabular}




\begin{tabular}{|c|c|c|c|c|c|c|c|c|c|c|c|c|}
\hline & $\begin{array}{l}\text { July 1, } \\
2020\end{array}$ & & & & & & & & & hospital & & \\
\hline 40 & unknown & Jan-21 & no & $\begin{array}{l}\text { direct } \\
\text { observer }\end{array}$ & 1053 & unknown & $15 \%$ & $68.2 \%$ & $\mathrm{n} / \mathrm{a}$ & $\begin{array}{l}\text { private } \\
\text { and } \\
\text { governm } \\
\text { ent- } \\
\text { subsidiz } \\
\text { ed } \\
\text { RCHs }\end{array}$ & $\begin{array}{l}\text { healthcare } \\
\text { worker }\end{array}$ & Hong Kong \\
\hline 41 & $\begin{array}{l}\text { February } \\
7 \text { to } 25, \\
2020\end{array}$ & 2020 & no & $\begin{array}{l}\text { direct } \\
\text { observer }\end{array}$ & 11680 & $\begin{array}{l}12208 \\
\text { people }\end{array}$ & $\mathrm{n} / \mathrm{a}$ & $\begin{array}{l}\text { for } \\
\text { women, } \\
70.5 \% \text { and } \\
\text { men } 50 \%\end{array}$ & $\mathrm{n} / \mathrm{a}$ & $\begin{array}{l}\text { residenti } \\
\text { al areas, } \\
\text { shoppin } \\
\mathrm{g} \\
\text { districts, } \\
\text { office } \\
\text { quarters }\end{array}$ & $\begin{array}{l}\text { adults and } \\
\text { children } \\
\text { over } 2 \text { in } \\
\text { general } \\
\text { population. }\end{array}$ & $\begin{array}{l}\text { Taipei and } \\
\text { major } \\
\text { satellite } \\
\text { cities in } \\
\text { New Taipei }\end{array}$ \\
\hline 42 & $\begin{array}{l}10 \text { weeks } \\
\text { before the } \\
\text { time of } \\
\text { the school } \\
\text { closures } \\
\text { (the week } \\
\text { beginning } \\
\text { January } 5 \\
\text { through } \\
\text { the week } \\
\text { beginning } \\
\text { March 8) } \\
\text { with the } \\
10 \text {-week } \\
\text { period } \\
\text { after } \\
\text { school } \\
\text { closures } \\
\text { (the week } \\
\text { beginning } \\
\text { March } 15 \\
\text { through } \\
\text { the week }\end{array}$ & Jan-21 & no & $\begin{array}{l}\text { automate } \\
\text { d } \\
\text { technolog } \\
\text { y hand } \\
\text { sanitizer } \\
\text { event } \\
\text { measurem } \\
\text { ent }\end{array}$ & $35,362,136$ & unknown & $\begin{array}{l}48.52 \% \\
\text { before } \\
\text { the } \\
\text { school } \\
\text { closure } \\
\text { s to } \\
58.05 \% \\
\text { after }\end{array}$ & $\mathrm{n} / \mathrm{a}$ & $\mathrm{n} / \mathrm{a}$ & $\begin{array}{l}9 \text { US } \\
\text { hospitals }\end{array}$ & $\begin{array}{l}\text { healthcare } \\
\text { workers/gen } \\
\text { eral public }\end{array}$ & USA \\
\hline
\end{tabular}




\begin{tabular}{|c|c|c|c|c|c|c|c|c|c|c|c|c|}
\hline & $\begin{array}{l}\text { beginning } \\
\text { May 17). }\end{array}$ & & & & & & & & & & & \\
\hline 43 & $\begin{array}{l}\text { Mar } 2020 \\
\text { - Jun } \\
\text { 2020) }\end{array}$ & Nov-20 & no & $\begin{array}{l}\text { mixed } \\
\text { methods. } \\
\text { automate } \\
\text { d } \\
\text { technolog } \\
\text { y hand } \\
\text { sanitizer } \\
\text { event } \\
\text { measurem } \\
\text { ent and } \\
\text { observer }\end{array}$ & 593,118 & unknown & $\begin{array}{l}85 \% \\
\text { hospita } \\
1 \text { wide } \\
\text { and } \\
90 \% \\
\text { on } \\
\text { COVI } \\
\text { D-19 } \\
\text { wards }\end{array}$ & $\mathrm{n} / \mathrm{a}$ & $\mathrm{n} / \mathrm{a}$ & $\begin{array}{l}\text { inpatient } \\
\text { areas of } \\
\text { the } \\
\text { hospital }\end{array}$ & $\begin{array}{l}\text { healthcare } \\
\text { workers }\end{array}$ & USA \\
\hline
\end{tabular}




\begin{tabular}{|c|c|c|c|c|c|c|c|c|c|c|c|c|}
\hline 44 & $\begin{array}{l}\text { April to } \\
\text { July } 2020\end{array}$ & Apr-21 & yes & $\begin{array}{l}\text { direct } \\
\text { observer }\end{array}$ & 60 & 60 & $\mathrm{n} / \mathrm{a}$ & $\mathrm{n} / \mathrm{a}$ & $78.3 \%$ & $\begin{array}{l}\text { regional } \\
\text { hospital } \\
\text { in } \\
\text { Korea. }\end{array}$ & $\begin{array}{l}\text { healthcare } \\
\text { workers }\end{array}$ & Korea \\
\hline
\end{tabular}




\begin{tabular}{|c|c|c|c|c|c|c|c|c|c|c|c|c|}
\hline 45 & $\begin{array}{l}\text { March and } \\
\text { April } \\
2020\end{array}$ & $\begin{array}{l}\text { April } \\
2020\end{array}$ & no & $\begin{array}{l}\text { direct } \\
\text { observer }\end{array}$ & unknown & unknown & $97 \%$ & $\mathrm{n} / \mathrm{a}$ & $\mathrm{n} / \mathrm{a}$ & $\begin{array}{l}\text { tertiary } \\
\text { care } \\
\text { hospital } \\
\text { Pakistan }\end{array}$ & $\begin{array}{l}\text { healthcare } \\
\text { workers }\end{array}$ & Pakistan \\
\hline
\end{tabular}




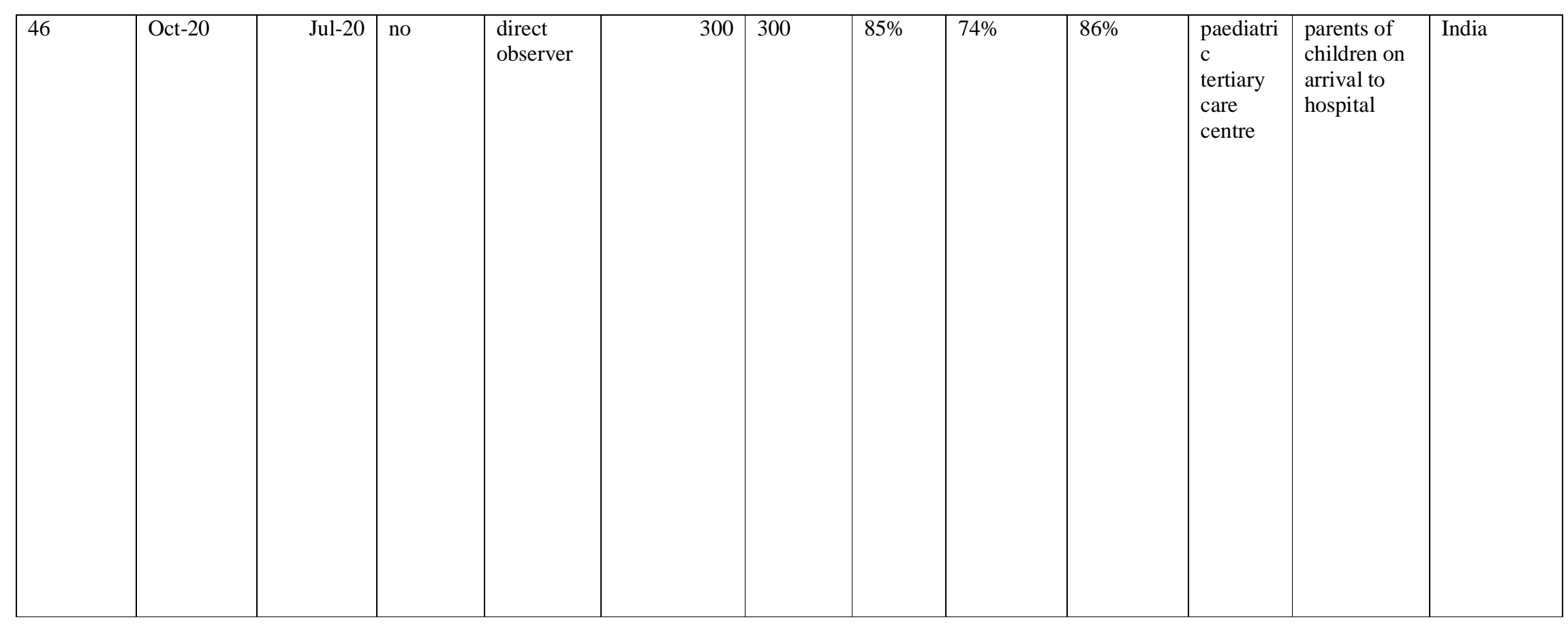




\begin{tabular}{|c|c|c|c|c|c|c|c|c|c|c|c|c|}
\hline 47 & unknown & Sep-20 & no & $\begin{array}{l}\text { direct } \\
\text { observer }\end{array}$ & 400 & 48 & $\begin{array}{l}45.6 \% \text {. } \\
\text { highest } \\
\text { after } \\
\text { contact } \\
\text { with } \\
\text { body } \\
\text { fluid } \\
\text { (65.1\% } \\
\text { ) and } \\
\text { lowest } \\
\text { after } \\
\text { touchin } \\
\text { g a } \\
\text { patient } \\
(29.5 \% \\
) \text {. }\end{array}$ & $\mathrm{n} / \mathrm{a}$ & $\mathrm{n} / \mathrm{a}$ & $\begin{array}{l}\text { home } \\
\text { health } \\
\text { care }\end{array}$ & $\begin{array}{l}\text { healthcare } \\
\text { workers }\end{array}$ & USA \\
\hline
\end{tabular}




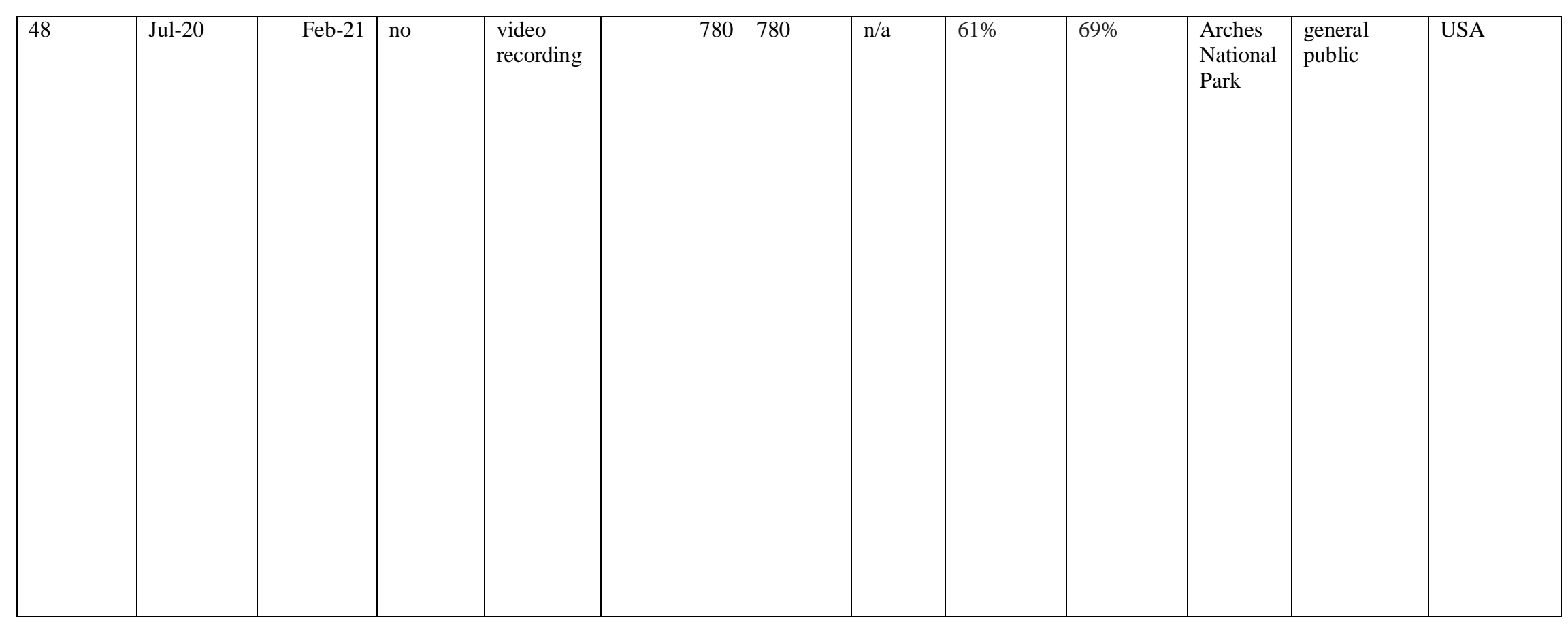


Table 3: Characteristics of included studies aim 3 (Non COVID-19)

\begin{tabular}{|c|c|c|c|c|c|c|c|c|c|c|}
\hline $\begin{array}{l}\text { Stud } \\
\text { y }\end{array}$ & $\begin{array}{l}\text { Date of } \\
\text { observation }\end{array}$ & $\begin{array}{l}\text { Date } \\
\text { of } \\
\text { pub }\end{array}$ & Study design & $\begin{array}{l}\text { Number of } \\
\text { events }\end{array}$ & Sample size & $\begin{array}{l}\text { Hand } \\
\text { hygiene } \\
\text { adherence } \\
\text { observed }\end{array}$ & $\begin{array}{l}\text { Self-reported } \\
\text { prevalence }\end{array}$ & $\begin{array}{l}\text { Where did } \\
\text { observations } \\
\text { take place }\end{array}$ & $\begin{array}{l}\text { Population } \\
\text { observed }\end{array}$ & $\begin{array}{l}\text { Other location } \\
\text { data }\end{array}$ \\
\hline 1 & unknown & 2006 & $\begin{array}{l}\text { direct } \\
\text { observer/surve } \\
\mathrm{y}\end{array}$ & 890 & 60 & $\begin{array}{l}\text { period } 1, \\
\text { student hand } \\
\text { hygiene was } \\
49.1 \% \text {, } \\
\text { mentors } \\
44.3 \% \\
\text { during } \\
\text { observationa } \\
\text { l period 2, } \\
\text { student hand } \\
\text { hygiene was } \\
52.3 \% \text {, } \\
\text { mentor } \\
53.3 \% \text {. }\end{array}$ & $\begin{array}{l}\text { students } \\
\text { reported } 92.98 \\
\text { before patient } \\
\text { contact, } 95.53 \\
\text { for commitment } \\
\text { to handwashing } \\
\text { after patient } \\
\text { contact, } 84.89 \\
\text { before donning } \\
\text { gloves, and } \\
95.11 \text { after } \\
\text { removal of } \\
\text { gloves. } \\
\text { Based on a scale } \\
\text { of } 10-100.10 \\
\text { being lowest } \\
\text { possible. }\end{array}$ & hospital setting & $\begin{array}{l}\text { sixty students } \\
\text { enrolled in a } \\
\text { certified } \\
\text { nursing } \\
\text { program were } \\
\text { selected to } \\
\text { participate in } \\
\text { the study. }\end{array}$ & USA \\
\hline 2 & $\begin{array}{l}\text { unknown } \\
\text { but } \\
\text { questionnair } \\
\text { e was } 1 \text { year } \\
\text { before } \\
\text { observation } \\
\text { s }\end{array}$ & 2002 & $\begin{array}{l}\text { questionnaire, } \\
\text { observation } \\
\text { and hand } \\
\text { bacteria } \\
\text { measurement }\end{array}$ & $\begin{array}{l}555 \text { observed } \\
\text { hand hygiene } \\
\text { opportunities }\end{array}$ & $\begin{array}{l}13 \text { observed, } \\
51 \text { survey } \\
\text { responses } \\
\text { (from a } \\
\text { conference - } \\
\text { not the same } \\
\text { people) }\end{array}$ & $\begin{array}{l}31.4 \% \text { of all } \\
\text { opportunitie } \\
\text { s; } 53.9 \% 1-5 \\
\text { times a day; } \\
38.5 \% \text { only } \\
\text { after contact } \\
\text { with } \\
\text { infected } \\
\text { material; }\end{array}$ & $\begin{array}{l}37.3 \% \text { following } \\
\text { contact with } \\
\text { contaminant; } \\
35.3 \% \text { prior to } \\
\text { every patient } \\
\text { examination; } \\
27.5 \% 1-5 \text { times } \\
\text { a day } 3.9 \% \\
\text { following every }\end{array}$ & $\begin{array}{l}\text { two outpatient } \\
\text { dermatology } \\
\text { clinics }\end{array}$ & physicians & Israel \\
\hline
\end{tabular}




\begin{tabular}{|c|c|c|c|c|c|c|c|c|c|c|}
\hline & & & & & & $\begin{array}{l}7.7 \% \text { before } \\
\text { each } \\
\text { physical } \\
\text { examination }\end{array}$ & $\begin{array}{l}\text { patient exam; } \\
3.9 \% \text { once per } \\
\text { hour }\end{array}$ & & & \\
\hline 3 & $\begin{array}{l}\text { October } \\
\text { 1999-April } \\
2000\end{array}$ & 2001 & $\begin{array}{l}\text { questionnaire, } \\
\text { observation }\end{array}$ & not reported & $\begin{array}{l}61 \text { artists } \\
\text { surveyed, } 25 \\
\text { of whom } \\
\text { were } \\
\text { observed }\end{array}$ & $71 \%$ & $83 \%$ & $\begin{array}{l}29 \\
\text { professional } \\
\text { tattoo studios }\end{array}$ & $\begin{array}{l}\text { professional } \\
\text { tattooists }\end{array}$ & $\begin{array}{l}\text { the seven-county } \\
\text { metropolitan area } \\
\text { of Minneapolis } \\
\text { and St. Paul, } \\
\text { Minnesota }\end{array}$ \\
\hline 4 & Sep-02 & $\begin{array}{r}\text { Nov- } \\
04\end{array}$ & $\begin{array}{l}\text { questionnaire, } \\
\text { observation }\end{array}$ & not reported & $\begin{array}{l}1050 \text { survey } \\
\text { responses, } \\
206 \text { observed }\end{array}$ & $74 \%$ & $74 \%$ & $\begin{array}{l}25 \text { care units } \\
\text { within a } \\
\text { University } \\
\text { Hospital }\end{array}$ & $\begin{array}{l}\text { medical staff } \\
\text { (physicians, } \\
\text { nurses, nursing } \\
\text { assistants) }\end{array}$ & $\begin{array}{l}\text { Nantes University } \\
\text { Hospital, France }\end{array}$ \\
\hline 5 & $\begin{array}{l}\text { July-Sept } \\
1989\end{array}$ & Jan-92 & $\begin{array}{l}\text { questionnaire, } \\
\text { observation }\end{array}$ & $\begin{array}{l}1,018 \\
\text { procedures } \\
\text { were } \\
\text { reported x } 4 \\
\text { outcomes = } \\
4072\end{array}$ & $\begin{array}{l}66 \text { survey } \\
\text { responses, } 88 \\
\text { staff working } \\
\text { (not reported } \\
\text { how many } \\
\text { were } \\
\text { observed) }\end{array}$ & $\begin{array}{l}\text { face } \\
\text { covering } \\
1.2 \%\end{array}$ & $\begin{array}{l}\text { face coverings: } \\
25.5 \%\end{array}$ & $\begin{array}{l}\text { emergency } \\
\text { department of } \\
\text { a university } \\
\text { hospital }\end{array}$ & $\begin{array}{l}\text { medical staff } \\
\text { (12 staff } \\
\text { physicians, } \\
\text { five to ten } \\
\text { resident } \\
\text { physicians, } \\
\text { physician } \\
\text { assistants } \\
\text { registered } \\
\text { nurses, nursing } \\
\text { assistants and } \\
\text { other ancillary } \\
\text { and support } \\
\text { staff) } \\
\text { healthcare } \\
\text { workers }\end{array}$ & $\begin{array}{l}\text { urban, the } \\
\text { Minneapolis/StPa } \\
\text { ul (twin cities) } \\
\text { metropolitan area }\end{array}$ \\
\hline
\end{tabular}




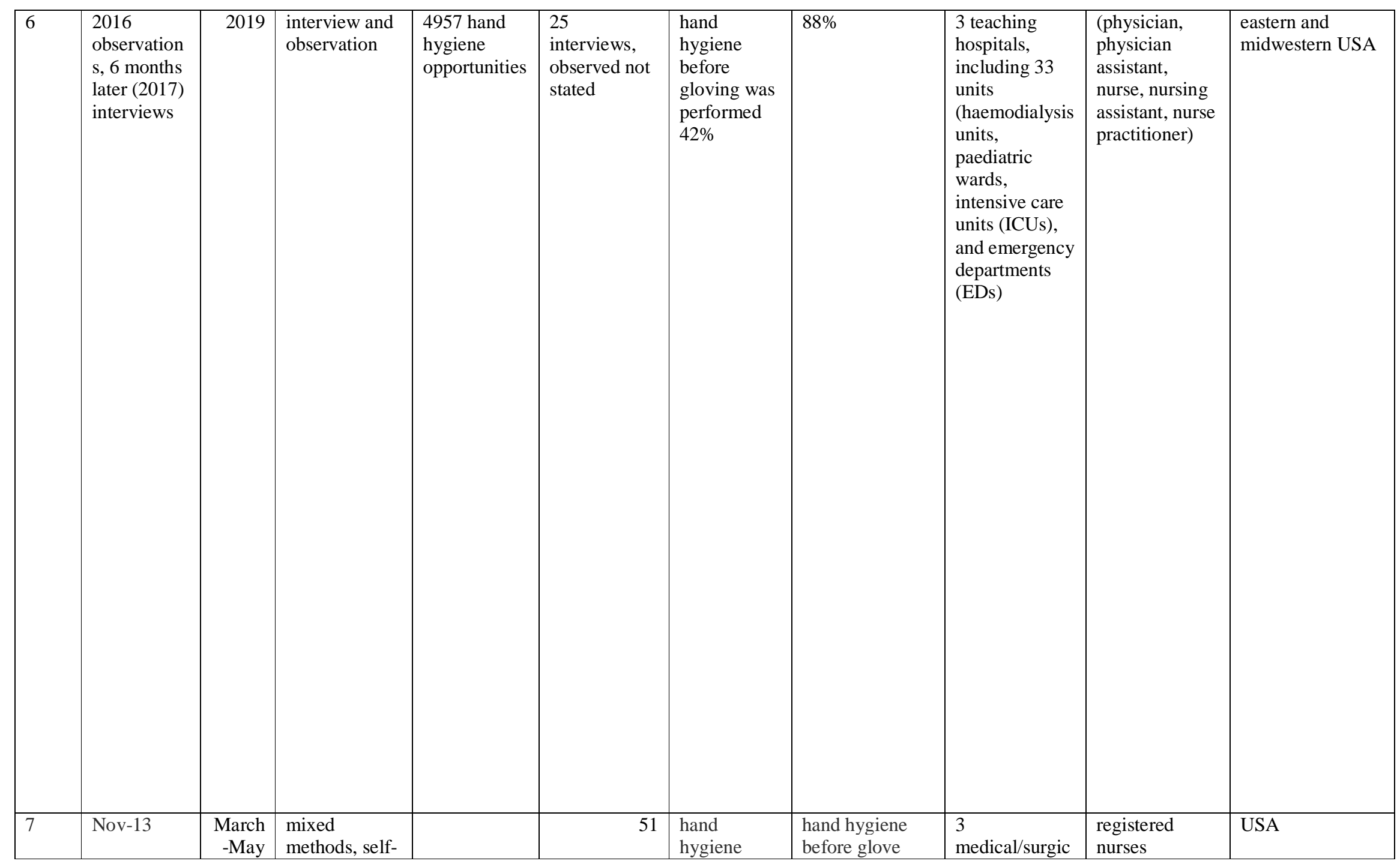




\begin{tabular}{|c|c|c|c|c|c|c|c|c|c|c|}
\hline & & 2012 & $\begin{array}{l}\text { report and } \\
\text { direct } \\
\text { observed by } \\
\text { observer }\end{array}$ & 91 & & $\begin{array}{l}\text { before glove } \\
\text { application, } \\
\text { was present } \\
\text { in } 14 \% \text { of } \\
\text { the CMCs } \\
\text { and } 21 \% \text { of } \\
\text { the } \\
\text { MDAMCs }\end{array}$ & $\begin{array}{l}\text { application } \\
\text { CMCs }(63 \%) \\
\text { MDAMCs }(50 \% \\
) \text {. hand hygiene } \\
\text { on room exit } \\
\text { CMCs (84\%) } \\
\text { MDAMCs } \\
(94 \%)\end{array}$ & $\begin{array}{l}\text { al units at } 2 \\
\text { medical } \\
\text { centres within } \\
\text { the south- } \\
\text { eastern United } \\
\text { States. One } \\
\text { was a 44-bed } \\
\text { medical/surgic } \\
\text { al unit at a } \\
\text { 110-bed } \\
\text { community } \\
\text { medical centre } \\
\text { (CMC) and the } \\
\text { other } 2 \text { units } \\
\text { were } 28 \text {-bed } \\
\text { medical/surgic } \\
\text { al units at a } \\
600 \text { bed } \\
\text { magnet- } \\
\text { designated } \\
\text { academic } \\
\text { medical centre } \\
\text { (MDAMC) }\end{array}$ & $\begin{array}{l}\text { comprised } 78 \% \\
\text { of the total } \\
\text { sample of } \\
\text { respondents. } \\
\text { Although } \\
\text { physicians and } \\
\text { therapy } \\
\text { providers were } \\
\text { invited to } \\
\text { participate, } \\
\text { none } \\
\text { completed the } \\
\text { survey. } \\
\text { Therefore, } \\
\text { results focus } \\
\text { on licensed and } \\
\text { unlicensed } \\
\text { nursing staff. }\end{array}$ & \\
\hline 8 & unknown & $\begin{array}{l}\text { Feb- } \\
19\end{array}$ & $\begin{array}{l}\text { mixed } \\
\text { methods: } \\
\text { direct } \\
\text { observer and } \\
\text { survey }\end{array}$ & 997 & $\begin{array}{l}371 \text { survey } \\
\text { participants. } \\
997 \text { people } \\
\text { observed }\end{array}$ & $\begin{array}{l}\text { physicians } \\
\text { had the } \\
\text { lowest rate } \\
\text { of } \\
\text { compliance } \\
\text { at } 14.6 \% \text {, } \\
\text { while nurses } \\
\text { had the } \\
\text { highest rate } \\
\text { of } \\
\text { compliance } \\
\text { at } 38.8 \% \text {. }\end{array}$ & $\begin{array}{l}\text { physicians had } \\
\text { the lowest rate } \\
(67.2 \%) \text { of self- } \\
\text { reported hand } \\
\text { hygiene } \\
\text { compliance, } \\
\text { while nurses had } \\
\text { the highest rate } \\
(97.8 \%) \text {, }\end{array}$ & $\begin{array}{l}11 \text { inpatient } \\
\text { service } \\
\text { departments } \\
\text { were chosen } \\
\text { for the study: } \\
\text { Five internal } \\
\text { medicine } \\
\text { services, five } \\
\text { paediatrics } \\
\text { services, and } \\
\text { one intensive } \\
\text { care unit } \\
\text { service }\end{array}$ & $\begin{array}{l}\text { the subjects of } \\
\text { the study were } \\
\text { healthcare } \\
\text { workers of } \\
\text { different } \\
\text { positions: } \\
\text { physicians, } \\
\text { nurses, care } \\
\text { assistants, and } \\
\text { student nurses. }\end{array}$ & Vietnam \\
\hline 9 & $\begin{array}{l}\text { April and } \\
\text { June } 2016\end{array}$ & $\begin{array}{l}\text { May } \\
2019\end{array}$ & $\begin{array}{l}\text { direct } \\
\text { observers and }\end{array}$ & $\begin{array}{l}811 \\
\text { opportunities }\end{array}$ & 87 & $\begin{array}{l}\text { overall hand } \\
\text { hygiene }\end{array}$ & $\begin{array}{l}\text { self-reported } \\
\text { hand hygiene }\end{array}$ & $\begin{array}{l}\text { University } \\
\text { Hospital }\end{array}$ & $\begin{array}{l}\text { healthcare } \\
\text { workers }\end{array}$ & Switzerland \\
\hline
\end{tabular}




\begin{tabular}{|c|c|c|c|c|c|c|c|c|c|c|}
\hline & & & survey & $\begin{array}{l}\text { observed. A } \\
\text { total of } 87 \\
\text { questionnair } \\
\text { es were } \\
\text { returned }\end{array}$ & & $\begin{array}{l}\text { compliance } \\
\text { was } 56 \% \\
\text { during } \\
\text { baseline and } \\
64 \% \text { during } \\
\text { intervention } \\
\text { period, } \\
\text { respectively. }\end{array}$ & $\begin{array}{l}\text { compliance did } \\
\text { not differ } \\
\text { between } \\
\text { baseline and } \\
\text { intervention } \\
\text { ( } 4.12 \text { vs } 4.03) \\
\text { on a Likert scale } \\
1-5,5 \text { being } \\
\text { always }\end{array}$ & Zurich & & \\
\hline 10 & $\begin{array}{l}\text { July-August } \\
2016\end{array}$ & $\begin{array}{l}\text { May- } \\
19\end{array}$ & $\begin{array}{l}\text { mixed } \\
\text { methods: } \\
\text { direct } \\
\text { observer and } \\
\text { survey, } \\
\text { interviews }\end{array}$ & 302. & $\begin{array}{l}104 \\
\text { observed, } \\
218 \text { survey }\end{array}$ & $\begin{array}{l}\text { hand } \\
\text { hygiene was } \\
35 \% \text { of all } \\
\text { opportunitie } \\
\text { s. Overall } \\
\text { entry and } \\
\text { exit hand } \\
\text { compliance } \\
\text { was } 90 \%\end{array}$ & $\begin{array}{l}81 \% \text { of the } \\
\text { sample } \\
\text { estimating they } \\
\text { miss performing } \\
\text { hand hygiene } \\
\text { when they } \\
\text { realize it should } \\
\text { be performed } \\
10 \%-20 \% \text { of the } \\
\text { time. An } \\
\text { additional } 11 \% \\
\text { reported missing } \\
\text { hand hygiene } \\
30 \%-40 \% \text { of the } \\
\text { time. } 4 \% \\
\text { estimated they } \\
\text { missed } \\
\text { performing hand } \\
\text { hygiene } 90 \%- \\
100 \% \text { of the } \\
\text { time. }\end{array}$ & $\begin{array}{l}\text { ICU at the } \\
\text { University of } \\
\text { Maryland } \\
\text { Medical } \\
\text { Center, a 750- } \\
\text { bed tertiary } \\
\text { care hospital in } \\
\text { Baltimore, } \\
\text { Maryland. }\end{array}$ & $\begin{array}{l}\text { healthcare } \\
\text { workers }\end{array}$ & USA \\
\hline 11 & unknown & $\begin{array}{l}\text { Oct- } \\
18\end{array}$ & $\begin{array}{l}\text { mixed } \\
\text { methods, self- } \\
\text { report and } \\
\text { direct } \\
\text { observed by } \\
\text { observer }\end{array}$ & $\begin{array}{l}249 \text { observed } \\
\text { hand hygiene }\end{array}$ & $\begin{array}{l}87 \\
\text { participants } \\
\text { (46 medical } \\
\text { doctors, } 21 \\
\text { from the } \\
\text { public } \\
\text { hospital, } 9 \\
\text { from the }\end{array}$ & $\begin{array}{l}\text { physicians } \\
(27 \%) \text { and } \\
\text { nurses } \\
(29 \%)\end{array}$ & $\begin{array}{l}\text { Likert scale. } \\
\text { Physicians mean } \\
\text { self-report was } \\
10.19 / 15 \text { based } \\
\text { on } 3 \text { hand } \\
\text { hygiene } \\
\text { opportunities, } \\
\text { and nurses was }\end{array}$ & $\begin{array}{l}\text { outpatient } \\
\text { examination } \\
\text { rooms and } \\
\text { emergency } \\
\text { departments of } \\
\text { three types of } \\
\text { hospitals }\end{array}$ & $\begin{array}{l}87 \text { physicians } \\
\text { and nurses } \\
\text { recruited while } \\
\text { on duty during } \\
\text { the scheduled } \\
\text { observation } \\
\text { periods, with } \\
\text { each healthcare }\end{array}$ & $\begin{array}{l}\text { Eastern region of } \\
\text { Saudi Arabia }\end{array}$ \\
\hline
\end{tabular}




\begin{tabular}{|c|c|c|c|c|c|c|c|c|c|c|}
\hline & & & & & $\begin{array}{l}\text { private clinic, } \\
\text { and } 16 \text { from } \\
\text { the Security } \\
\text { Forces; and } \\
41 \text { nurses, } 14 \\
\text { from the } \\
\text { public } \\
\text { hospital, } 9 \\
\text { from the } \\
\text { private clinic, } \\
\text { and } 18 \text { from } \\
\text { the security } \\
\text { forces } \\
\text { hospital) } \\
\text { were } \\
\text { recruited. Of } \\
\text { the } 87 \\
\text { participants } \\
\text { who } \\
\text { completed } \\
\text { the } \\
\text { questionnaire } \\
\text {, } 83 \\
\text { participants } \\
\text { were } \\
\text { observed } \\
\text { during exams } \\
\text { with at least } \\
\text { three patients } \\
\text { and hand } \\
\text { hygiene } \\
\text { practices } \\
\text { were } \\
\text { recorded } \\
\text { using the } \\
\text { checklist } \\
\end{array}$ & & $\begin{array}{l}13.65 / 15 \text { based } \\
\text { on } 3 \\
\text { opportunities. }\end{array}$ & 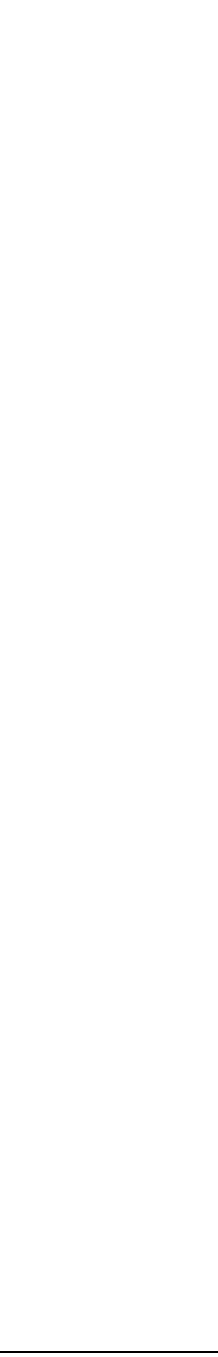 & $\begin{array}{l}\text { worker being } \\
\text { observed } \\
\text { during } \\
\text { individual } \\
\text { medical } \\
\text { examinations } \\
\text { with at least } \\
\text { three patients }\end{array}$ & \\
\hline 12 & unknown & 2011 & $\begin{array}{l}\text { survey self- } \\
\text { report vs }\end{array}$ & unknown & $\begin{array}{l}160 \text { medical } \\
\text { students in }\end{array}$ & $\begin{array}{l}\text { direct } \\
\text { observations }\end{array}$ & $87.90 \%$ & hospital setting & $\begin{array}{l}\text { medical } \\
\text { students }\end{array}$ & USA \\
\hline
\end{tabular}




\begin{tabular}{|c|c|c|c|c|c|c|c|c|c|c|}
\hline & & & $\begin{array}{l}\text { direct } \\
\text { observation }\end{array}$ & & $\begin{array}{l}\text { year } 3 \text { and } 98 \\
\text { in year } 4\end{array}$ & $\begin{array}{l}\text { reported } \\
\text { proper hand } \\
\text { hygiene in } \\
87.9 \%\end{array}$ & & & & \\
\hline 13 & $\begin{array}{l}\text { fourth } \\
\text { quarter of } \\
2011 \text { to } \\
82.3 \% \text { in } \\
\text { fourth } \\
\text { quarter of } \\
2012\end{array}$ & Jun-13 & $\begin{array}{l}\text { mixed } \\
\text { methods, self- } \\
\text { report and } \\
\text { direct } \\
\text { observed by } \\
\text { observer }\end{array}$ & unknown & unknown & $\begin{array}{l}\text { the overall } \\
\text { hand } \\
\text { hygiene } \\
\text { compliance } \\
\text { rate } \\
\text { increased } \\
\text { from a } \\
\text { baseline of } \\
49.7 \% \text { in } \\
\text { fourth } \\
\text { quarter of } \\
2011 \text { to } \\
82.3 \% \text { in } \\
\text { fourth } \\
\text { quarter of } \\
2012\end{array}$ & $\begin{array}{r}\text { increased from a } \\
\text { baseline of } \\
82.9 \% \text { to } 93.8 \%\end{array}$ & $\begin{array}{l}\text { healthcare } \\
\text { settings }\end{array}$ & $\begin{array}{l}\text { healthcare } \\
\text { workers } \\
\text { doctors }\end{array}$ & Korea \\
\hline
\end{tabular}




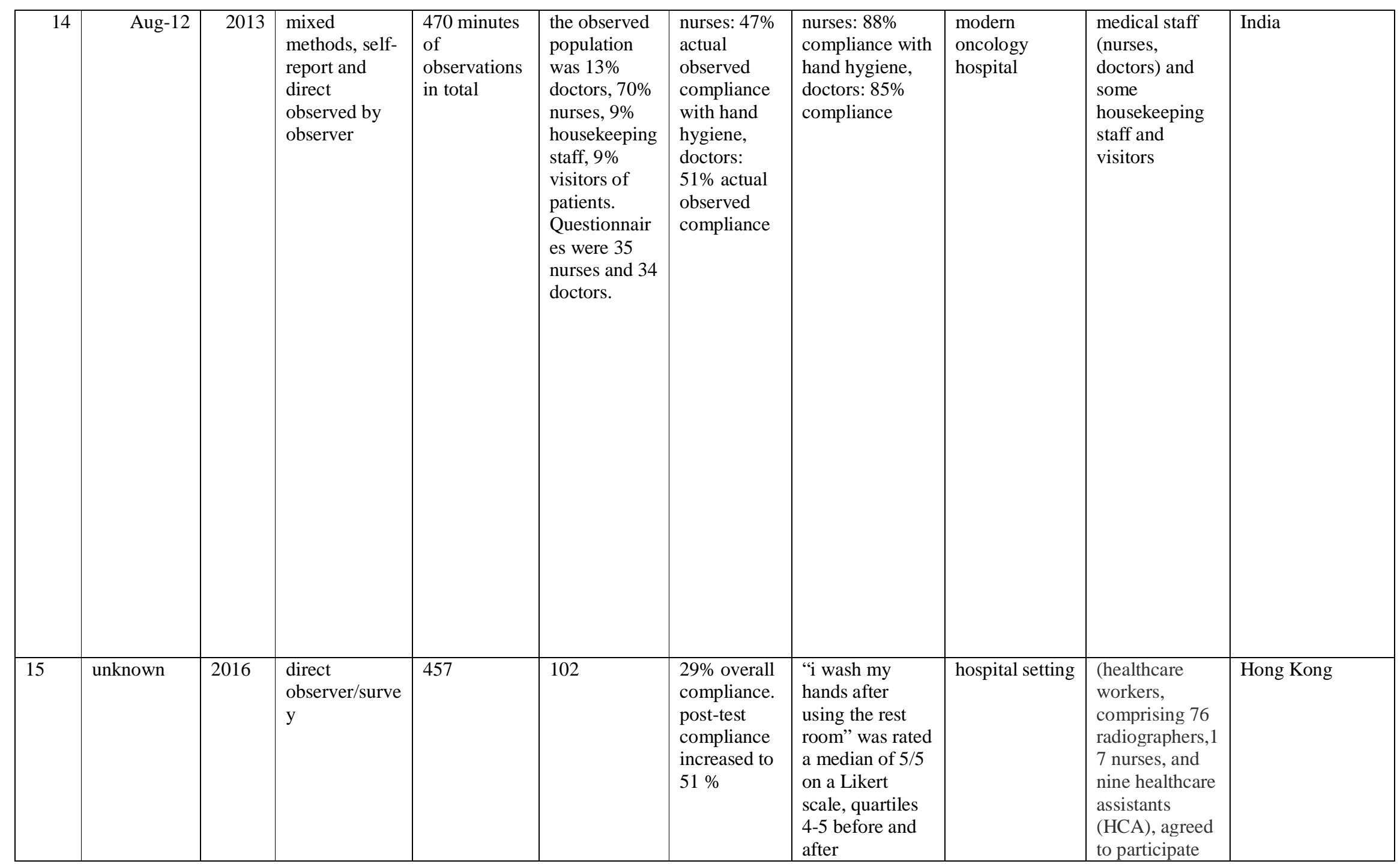




\begin{tabular}{|c|c|c|c|c|c|c|c|c|c|c|}
\hline & & & & & & & intervention & & in the study. & \\
\hline 16 & $\begin{array}{l}\text { the baseline } \\
\text { survey was } \\
\text { held from } \\
\text { May } \\
\text { through } \\
\text { August } \\
2008 \text { and } \\
\text { covered a } \\
\text { total of } \\
3576 \\
\text { households. } \\
\text { The follow- } \\
\text { up survey } \\
\text { was } \\
\text { conducted } \\
\text { following } \\
\text { the } \\
\text { completion } \\
\text { of the } \\
\text { project } \\
\text { activities } \\
\text { (March- } \\
\text { June 2011). }\end{array}$ & $\begin{array}{l}\text { Oct- } \\
15\end{array}$ & $\begin{array}{l}\text { survey self- } \\
\text { report vs } \\
\text { direct } \\
\text { observation }\end{array}$ & unknown & $\begin{array}{l}3576 \text { in } \\
\text { survey, 45-60 } \\
\text { households } \\
\text { observed }\end{array}$ & $\begin{array}{l}\text { handwashin } \\
\text { g with soap } \\
\text { was } \\
\text { observed in } \\
\text { only } 16 \% \text { of } \\
\text { the events } \\
\text { that required } \\
\text { it. } 20 \% \text { of } \\
\text { faecal } \\
\text { contact } \\
\text { events, } 25 \% \\
\text { of eating } \\
\text { events, } 6 \% \\
\text { of child } \\
\text { feeding } \\
\text { events, and } \\
10 \% \text { of food } \\
\text { preparation } \\
\text { events. }\end{array}$ & $\begin{array}{l}\text { although almost } \\
\text { all caregivers } \\
\text { reported having } \\
\text { washed their } \\
\text { hands with soap } \\
\text { at least once } \\
\text { during the } \\
\text { previous } 24 \mathrm{~h} \text {, } \\
\text { fewer than half } \\
\text { confirmed } \\
\text { having carried } \\
\text { out so at times } \\
\text { of faecal contact } \\
\text { (39\% of } \\
\text { caregivers } \\
\text { associated } \\
\text { handwashing } \\
\text { with soap with } \\
\text { toilet use and } \\
34 \% \text { with } \\
\text { cleaning up after } \\
\text { children). } \\
\text { cooking or food } \\
\text { preparation } \\
\text { (68\%), but } \\
\text { lower when } \\
\text { feeding a child } \\
\text { (31\%). }\end{array}$ & households & general public & Peru \\
\hline 17 & unknown & Jun-15 & $\begin{array}{l}\text { survey self- } \\
\text { report vs } \\
\text { direct } \\
\text { observation }\end{array}$ & unknown & $\begin{array}{l}\text { sixty nine } \\
\text { respondents } \\
\text { participated } \\
\text { in the survey } \\
\text { which } \\
\text { predominantl } \\
\text { y included } \\
\text { the nurses }\end{array}$ & $\begin{array}{l}\text { use of } \\
\text { alcohol } \\
\text { based hand } \\
\text { rub } 94.2 \%, \\
\text { five } \\
\text { moments of } \\
\text { hand } \\
\text { hygiene } \\
88.5 \%, 6\end{array}$ & $\begin{array}{l}\text { use of alcohol } \\
\text { based hand rub } \\
98.5, \text { five } \\
\text { moments of } \\
\text { hand hygiene Q } \\
88.5,6 \text { steps of } \\
\text { hand hygiene Q- } \\
92.5\end{array}$ & $\begin{array}{l}\text { in ICU in an } \\
\text { oncology, } \\
\text { BMT and } \\
\text { neurosurgical } \\
\text { centre in South } \\
\text { India }\end{array}$ & $\begin{array}{l}\text { healthcare } \\
\text { workers mostly } \\
\text { nurses }\end{array}$ & South India \\
\hline
\end{tabular}




\begin{tabular}{|c|c|c|c|c|c|c|c|c|c|c|}
\hline & & & & & & $\begin{array}{l}\text { steps of } \\
\text { hand } \\
\text { hygiene } \\
65 \% \text {. }\end{array}$ & & & & \\
\hline 18 & $2015-2016$ & $\begin{array}{l}\text { Feb- } \\
2019\end{array}$ & $\begin{array}{l}\text { survey self- } \\
\text { report vs } \\
\text { direct } \\
\text { observation }\end{array}$ & 127 & $\begin{array}{l}639,127 \text { of } \\
\text { these } \\
\text { healthcare } \\
\text { workers had } \\
\text { been also } \\
\text { directly } \\
\text { observed. }\end{array}$ & $67.7 \%$ & $74 \%$ & hospital setting & $\begin{array}{l}\text { healthcare } \\
\text { workers } \\
\text { physicians and } \\
\text { nurses }\end{array}$ & $\begin{array}{l}5 \text { hospitals in } \\
\text { Slovakia and } 3 \text { in } \\
\text { Czech republic }\end{array}$ \\
\hline
\end{tabular}




\section{Search Strategy}

EMBASE SEARCH COVID-19 papers Aim 1 and 2

1. exp coronavirus disease 2019/

2. exp Severe acute respiratory syndrome coronavirus $2 /$

3. $\exp$ Coronavirinae/

4. COVID-19-19.mp. [mp=title, abstract, heading word, drug trade name, original title, device manufacturer, drug manufacturer, device trade name, keyword, floating subheading word, candidate term word]

5. coronavirus.mp. [mp=title, abstract, heading word, drug trade name, original title, device manufacturer, drug manufacturer, device trade name, keyword, floating subheading word, candidate term word]

6. COVID-19.mp. [mp=title, abstract, heading word, drug trade name, original title, device manufacturer, drug manufacturer, device trade name, keyword, floating subheading word, candidate term word]

\section{1 or 2 or 3 or 4 or 5 or 6}

8. exp hand washing/

9. (hand adj3 wash*).mp. [mp=title, abstract, heading word, drug trade name, original title, device manufacturer, drug manufacturer, device trade name, keyword, floating subheading word, candidate term word] 
10. (hand adj3 hygiene).mp. [mp=title, abstract, heading word, drug trade name, original title, device manufacturer, drug manufacturer, device trade name, keyword, floating subheading word, candidate term word]

11. (hand adj3 sanit*).mp. [mp=title, abstract, heading word, drug trade name, original title, device manufacturer, drug manufacturer, device trade name, keyword, floating subheading word, candidate term word]

12. (hand adj3 disinect*).mp. [mp=title, abstract, heading word, drug trade name, original title, device manufacturer, drug manufacturer, device trade name, keyword, floating subheading word, candidate term word]

13. hand-sanit*.mp. [mp=title, abstract, heading word, drug trade name, original title, device manufacturer, drug manufacturer, device trade name, keyword, floating subheading word, candidate term word]

14. (hand adj3 clean*).mp. [mp=title, abstract, heading word, drug trade name, original title, device manufacturer, drug manufacturer, device trade name, keyword, floating subheading word, candidate term word]

15. hand-wash*.mp. [mp=title, abstract, heading word, drug trade name, original title, device manufacturer, drug manufacturer, device trade name, keyword, floating subheading word, candidate term word]

16. hand-hygiene.mp. [mp=title, abstract, heading word, drug trade name, original title, device manufacturer, drug manufacturer, device trade name, keyword, floating subheading word, candidate term word]

17.8 or 9 or 10 or 11 or 12 or 13 or 14 or 15 or 16 
18. exp face mask ventilation/ or exp mask/ or exp cloth mask/ or exp face mask/ or exp pediatric face mask/ or exp surgical mask/

19. (face adj3 cover*).mp. [mp=title, abstract, heading word, drug trade name, original title, device manufacturer, drug manufacturer, device trade name, keyword, floating subheading word, candidate term word]

20. mask*.mp.

21. (wear adj3 mask).mp. [mp=title, abstract, heading word, drug trade name, original title, device manufacturer, drug manufacturer, device trade name, keyword, floating subheading word, candidate term word]

22. (facial adj3 cover*).mp. [mp=title, abstract, heading word, drug trade name, original title, device manufacturer, drug manufacturer, device trade name, keyword, floating subheading word, candidate term word]

23. (facial adj3 mask).mp. [mp=title, abstract, heading word, drug trade name, original title, device manufacturer, drug manufacturer, device trade name, keyword, floating subheading word, candidate term word]

24. facial-cover*.mp. [ $\mathrm{mp}=$ title, abstract, heading word, drug trade name, original title, device manufacturer, drug manufacturer, device trade name, keyword, floating subheading word, candidate term word]

25. (wore adj3 mask).mp. [mp=title, abstract, heading word, drug trade name, original title, device manufacturer, drug manufacturer, device trade name, keyword, floating subheading word, candidate term word]

26. 18 or 19 or 20 or 21 or 22 or 23 or 24 or 25 


\section{7. exp social distancing/}

28. (social* adj3 distanc*).mp. [mp=title, abstract, heading word, drug trade name, original title, device manufacturer, drug manufacturer, device trade name, keyword, floating subheading word, candidate term word]

29. (physical* adj3 distanc*).mp. [mp=title, abstract, heading word, drug trade name, original title, device manufacturer, drug manufacturer, device trade name, keyword, floating subheading word, candidate term word]

30. (safe adj3 distanc*).mp. [mp=title, abstract, heading word, drug trade name, original title, device manufacturer, drug manufacturer, device trade name, keyword, floating subheading word, candidate term word]

31. 27 or 28 or 29 or 30

32. CCTV.mp.

33. (closed adj3 circuit adj3 television).mp. [ $\mathrm{mp}=$ title, abstract, heading word, drug trade name, original title, device manufacturer, drug manufacturer, device trade name, keyword, floating subheading word, candidate term word]

34. exp videorecording/

35. (surveillance adj3 camera).mp. [ $\mathrm{mp}=$ title, abstract, heading word, drug trade name, original title, device manufacturer, drug manufacturer, device trade name, keyword, floating subheading word, candidate term word]

36. 32 or 33 or 34 or 35

37. exp observational study/ or exp observational method/ 
38. observ*.mp. [mp=title, abstract, heading word, drug trade name, original title, device manufacturer, drug manufacturer, device trade name, keyword, floating subheading word, candidate term word]

39. 37 or 38

40. 17 or 26 or 31

41. 7 and 40

42. 39 and 41

43. 7 and 36 and 40

44. 42 or 43

MEDLINE SEARCH COVID-19 papers Aim 1 and 2

1. exp COVID-19-19/

2. $\exp$ SARS-CoV-2/

3. exp Coronavirus/

4. COVID-19-19.mp. [mp=title, abstract, original title, name of substance word, subject heading word, floating sub-heading word, keyword heading word, organism supplementary concept word, protocol supplementary concept word, rare disease supplementary concept word, unique identifier, synonyms]

5. coronavirus.mp. [mp=title, abstract, original title, name of substance word, subject heading word, floating sub-heading word, keyword heading word, organism supplementary concept word, protocol supplementary concept word, rare disease supplementary concept word, unique identifier, synonyms] 
6. COVID-19.mp. [mp=title, abstract, original title, name of substance word, subject heading word, floating sub-heading word, keyword heading word, organism supplementary concept word, protocol supplementary concept word, rare disease supplementary concept word, unique identifier, synonyms]

7. 1 or 2 or 3 or 4 or 5 or 6

\section{8. exp Hand Disinfection/}

9. (hand adj3 wash*).mp. [mp=title, abstract, original title, name of substance word, subject heading word, floating sub-heading word, keyword heading word, organism supplementary concept word, protocol supplementary concept word, rare disease supplementary concept word, unique identifier, synonyms]

10. (hand adj3 hygiene).mp. [mp=title, abstract, original title, name of substance word, subject heading word, floating sub-heading word, keyword heading word, organism supplementary concept word, protocol supplementary concept word, rare disease supplementary concept word, unique identifier, synonyms]

11. (hand adj3 sanit*).mp. [mp=title, abstract, original title, name of substance word, subject heading word, floating sub-heading word, keyword heading word, organism supplementary concept word, protocol supplementary concept word, rare disease supplementary concept word, unique identifier, synonyms]

12. (hand adj3 disinfect*).mp. [ $\mathrm{mp}=$ title, abstract, original title, name of substance word, subject heading word, floating sub-heading word, keyword heading word, organism supplementary concept word, protocol supplementary concept word, rare disease supplementary concept word, unique identifier, synonyms] 
13. hand-sanit*.mp. [mp=title, abstract, original title, name of substance word, subject heading word, floating sub-heading word, keyword heading word, organism supplementary concept word, protocol supplementary concept word, rare disease supplementary concept word, unique identifier, synonyms]

14. (hand adj3 clean*).mp. [mp=title, abstract, original title, name of substance word, subject heading word, floating sub-heading word, keyword heading word, organism supplementary concept word, protocol supplementary concept word, rare disease supplementary concept word, unique identifier, synonyms]

15. hand-wash*.mp. [mp=title, abstract, original title, name of substance word, subject heading word, floating sub-heading word, keyword heading word, organism supplementary concept word, protocol supplementary concept word, rare disease supplementary concept word, unique identifier, synonyms]

16. hand-hygiene.mp. [ $\mathrm{mp}=$ title, abstract, original title, name of substance word, subject heading word, floating sub-heading word, keyword heading word, organism supplementary concept word, protocol supplementary concept word, rare disease supplementary concept word, unique identifier, synonyms]

17.8 or 9 or 10 or 11 or 12 or 13 or 14 or 15 or 16

18. exp Masks/

19. (face adj3 cover).mp. [mp=title, abstract, original title, name of substance word, subject heading word, floating sub-heading word, keyword heading word, organism supplementary concept word, protocol supplementary concept word, rare disease supplementary concept word, unique identifier, synonyms] 
20. mask*.mp. [mp=title, abstract, original title, name of substance word, subject heading word, floating sub-heading word, keyword heading word, organism supplementary concept word, protocol supplementary concept word, rare disease supplementary concept word, unique identifier, synonyms]

21. (wear adj3 mask).mp. [mp=title, abstract, original title, name of substance word, subject heading word, floating sub-heading word, keyword heading word, organism supplementary concept word, protocol supplementary concept word, rare disease supplementary concept word, unique identifier, synonyms]

22. (facial adj3 cover*).mp. [mp=title, abstract, original title, name of substance word, subject heading word, floating sub-heading word, keyword heading word, organism supplementary concept word, protocol supplementary concept word, rare disease supplementary concept word, unique identifier, synonyms]

23. (facial adj3 mask).mp. [ $\mathrm{mp}=$ title, abstract, original title, name of substance word, subject heading word, floating sub-heading word, keyword heading word, organism supplementary concept word, protocol supplementary concept word, rare disease supplementary concept word, unique identifier, synonyms]

24. facial-cover*.mp. [mp=title, abstract, original title, name of substance word, subject heading word, floating sub-heading word, keyword heading word, organism supplementary concept word, protocol supplementary concept word, rare disease supplementary concept word, unique identifier, synonyms]

25. (wore adj3 mask).mp. [mp=title, abstract, original title, name of substance word, subject heading word, floating sub-heading word, keyword heading word, organism supplementary concept word, protocol supplementary concept word, rare disease supplementary concept word, unique identifier, synonyms] 


\section{18 or 19 or 20 or 21 or 22 or 23 or 24 or 25}

27. exp Physical Distancing/

28. (social* adj3 distanc*).mp. [mp=title, abstract, original title, name of substance word, subject heading word, floating sub-heading word, keyword heading word, organism supplementary concept word, protocol supplementary concept word, rare disease supplementary concept word, unique identifier, synonyms]

29. (physical* adj3 distanc*).mp. [mp=title, abstract, original title, name of substance word, subject heading word, floating sub-heading word, keyword heading word, organism supplementary concept word, protocol supplementary concept word, rare disease supplementary concept word, unique identifier, synonyms]

30. (safe adj3 distanc*).mp. [mp=title, abstract, original title, name of substance word, subject heading word, floating sub-heading word, keyword heading word, organism supplementary concept word, protocol supplementary concept word, rare disease supplementary concept word, unique identifier, synonyms]

31. 27 or 28 or 29 or 30

32. exp Video Recording/

33. CCTV.mp. [ $m p=$ title, abstract, original title, name of substance word, subject heading word, floating sub-heading word, keyword heading word, organism supplementary concept word, protocol supplementary concept word, rare disease supplementary concept word, unique identifier, synonyms]

34. (closed adj3 circuit adj3 television).mp. [mp=title, abstract, original title, name of substance word, subject heading word, floating sub-heading word, keyword heading word, organism 
medRxiv preprint doi: https://doi.org/10.1101/2021.12.22.21268226; this version posted December 23, 2021. The copyright holder for this preprint (which was not certified by peer review) is the author/funder, who has granted medRxiv a license to display the preprint in perpetuity. It is made available under a CC-BY 4.0 International license .

supplementary concept word, protocol supplementary concept word, rare disease supplementary concept word, unique identifier, synonyms]

35. (surveillance adj3 camera).mp. [ $\mathrm{mp}=$ title, abstract, original title, name of substance word, subject heading word, floating sub-heading word, keyword heading word, organism supplementary concept word, protocol supplementary concept word, rare disease supplementary concept word, unique identifier, synonyms]

36. 32 or 33 or 34 or 35

37. exp Observational Study/

38. observ*.mp. [mp=title, abstract, original title, name of substance word, subject heading word, floating sub-heading word, keyword heading word, organism supplementary concept word, protocol supplementary concept word, rare disease supplementary concept word, unique identifier, synonyms]

39. 37 or 38

40. 17 or 26 or 31

41. 7 and 40

42. 39 and 41

43. 7 and 36 and 40

44. 42 or 43 


\section{SEARCH STRATEDGY Aim 3}

1. exp hand washing/

2. (hand adj3 wash*).mp. [mp=title, abstract, heading word, drug trade name, original title, device manufacturer, drug manufacturer, device trade name, keyword, floating subheading word, candidate term word]

3. (hand adj3 hygiene).mp. [mp=title, abstract, heading word, drug trade name, original title, device manufacturer, drug manufacturer, device trade name, keyword, floating subheading word, candidate term word]

4. (hand adj3 sanit*).mp. [mp=title, abstract, heading word, drug trade name, original title, device manufacturer, drug manufacturer, device trade name, keyword, floating subheading word, candidate term word]

5. (hand adj3 disinect*).mp. [mp=title, abstract, heading word, drug trade name, original title, device manufacturer, drug manufacturer, device trade name, keyword, floating subheading word, candidate term word]

6. hand-sanit*.mp. [mp=title, abstract, heading word, drug trade name, original title, device manufacturer, drug manufacturer, device trade name, keyword, floating subheading word, candidate term word]

7. (hand adj3 clean*).mp. [mp=title, abstract, heading word, drug trade name, original title, device manufacturer, drug manufacturer, device trade name, keyword, floating subheading word, candidate term word] 
8. hand-wash*.mp. [mp=title, abstract, heading word, drug trade name, original title, device manufacturer, drug manufacturer, device trade name, keyword, floating subheading word, candidate term word]

9. hand-hygiene.mp. [mp=title, abstract, heading word, drug trade name, original title, device manufacturer, drug manufacturer, device trade name, keyword, floating subheading word, candidate term word]

10. 1 or 2 or 3 or 4 or 5 or 6 or 7 or 8 or 9

11. exp face mask ventilation/ or exp mask/ or exp cloth mask/ or exp face mask/ or exp pediatric face mask/ or exp surgical mask/

12. (face adj3 cover*).mp. [ $\mathrm{mp}=$ title, abstract, heading word, drug trade name, original title, device manufacturer, drug manufacturer, device trade name, keyword, floating subheading word, candidate term word]

13. mask*.mp.

14. (wear adj3 mask).mp. [mp=title, abstract, heading word, drug trade name, original title, device manufacturer, drug manufacturer, device trade name, keyword, floating subheading word, candidate term word]

15. (facial adj3 cover*).mp. [ $m p=$ title, abstract, heading word, drug trade name, original title, device manufacturer, drug manufacturer, device trade name, keyword, floating subheading word, candidate term word]

16. (facial adj3 mask).mp. [mp=title, abstract, heading word, drug trade name, original title, device manufacturer, drug manufacturer, device trade name, keyword, floating subheading word, candidate term word] 
17. facial-cover*.mp. [mp=title, abstract, heading word, drug trade name, original title, device manufacturer, drug manufacturer, device trade name, keyword, floating subheading word, candidate term word]

18. (wore adj3 mask).mp. [mp=title, abstract, heading word, drug trade name, original title, device manufacturer, drug manufacturer, device trade name, keyword, floating subheading word, candidate term word]

19. 11 or 12 or 13 or 14 or 15 or 16 or 17 or 18

20. exp social distancing/

21. (social* adj3 distanc*).mp. [mp=title, abstract, heading word, drug trade name, original title, device manufacturer, drug manufacturer, device trade name, keyword, floating subheading word, candidate term word]

22. (physical* adj3 distanc*).mp. [mp=title, abstract, heading word, drug trade name, original title, device manufacturer, drug manufacturer, device trade name, keyword, floating subheading word, candidate term word]

23. (safe adj3 distanc*).mp. [mp=title, abstract, heading word, drug trade name, original title, device manufacturer, drug manufacturer, device trade name, keyword, floating subheading word, candidate term word]

24. 20 or 21 or 22 or 23

25. CCTV.mp.

26. (closed adj3 circuit adj3 television).mp. [ $\mathrm{mp}=$ title, abstract, heading word, drug trade name, original title, device manufacturer, drug manufacturer, device trade name, keyword, floating subheading word, candidate term word] 
medRxiv preprint doi: https://doi.org/10.1101/2021.12.22.21268226; this version posted December 23, 2021. The copyright holder for this preprint (which was not certified by peer review) is the author/funder, who has granted medRxiv a license to display the preprint in perpetuity. It is made available under a CC-BY 4.0 International license .

27. exp videorecording/

28. (surveillance adj3 camera).mp. [mp=title, abstract, heading word, drug trade name, original title, device manufacturer, drug manufacturer, device trade name, keyword, floating subheading word, candidate term word]

29. 25 or 26 or 27 or 28

30. exp observational study/ or exp observational method/

31. observ*.mp. [mp=title, abstract, heading word, drug trade name, original title, device manufacturer, drug manufacturer, device trade name, keyword, floating subheading word, candidate term word]

32. exp infection/

33. 10 or 19 or 24

34. 32 and 33

35. 30 or 31

36. 29 or 35

37. 34 and 36 
Table 4: COVID-19 Included papers in data synthesis

\begin{tabular}{|c|c|c|c|}
\hline & Title & Journal & Authors \\
\hline 1 & $\begin{array}{l}\text { Has the COVID-19 Virus } \\
\text { Changed Adherence to Hand } \\
\text { Washing among Healthcare } \\
\text { workers? }\end{array}$ & $\begin{array}{l}\text { Behav Sci } \\
\text { (Basel) }\end{array}$ & $\begin{array}{l}\text { Ragusa, Rosalia; Marranzano, Marina; Lombardo, } \\
\text { Alessandro; Quattrocchi, Rosalba; Bellia, Maria } \\
\text { Alessandra; Lupo, Lorenzo }\end{array}$ \\
\hline 2 & $\begin{array}{l}\text { Face touching in the time of } \\
\text { COVID-19 in Shiraz, Iran }\end{array}$ & $\begin{array}{l}\text { Am. J. Infect. } \\
\text { Control }\end{array}$ & Shiraly, Ramin; Shayan, Zahra; McLaws, Mary-Louise \\
\hline 3 & $\begin{array}{l}\text { Rational use of face mask in a } \\
\text { tertiary care hospital setting } \\
\text { during COVID-19 pandemic: } \\
\text { An observational study }\end{array}$ & $\begin{array}{l}\text { Indian J Public } \\
\text { Health }\end{array}$ & $\begin{array}{l}\text { Supehia, Sakshi; Sharma, Twinkle; Singh, Vanya; Khapre, } \\
\text { Meenakshi; Gupta, Puneet Kumar }\end{array}$ \\
\hline 4 & $\begin{array}{l}\text { Prevention measures for } \\
\text { COVID-19 in retail food stores } \\
\text { in Braga, Portugal }\end{array}$ & Pulmonology & Precioso, J.; Samorinha, C.; Alves, R. \\
\hline 5 & $\begin{array}{l}\text { Face-touching behaviour as a } \\
\text { possible correlate of mask- } \\
\text { wearing: A video observational } \\
\text { study of public place incidents } \\
\text { during the COVID-19 } \\
\text { pandemic }\end{array}$ & $\begin{array}{l}\text { Transboundary } \\
\text { Emer. Dis. }\end{array}$ & $\begin{array}{l}\text { Liebst, Lasse S.; Ejbye-Ernst, Peter; Thomas, Josephine; de } \\
\text { Bruin, Marijn; Lindegaard, Marie R. }\end{array}$ \\
\hline 6 & $\begin{array}{l}\text { Prevention of COVID-19 in } \\
\text { retail food stores in Portugal: } \\
\text { The importance of regulations } \\
\text { in behavioural change }\end{array}$ & Aten. Prim. & Precioso, Jose; Samorinha, Catarina \\
\hline 7 & $\begin{array}{l}\text { Behavioural insights and } \\
\text { attitudes on community } \\
\text { masking during the initial } \\
\text { spread of COVID-19 in Hong } \\
\text { Kong }\end{array}$ & $\begin{array}{l}\text { Hong Kong } \\
\text { Med. J. }\end{array}$ & $\begin{array}{l}\text { Tam, Victor C. W.; Tam, S.Y.; Law, Helen K. W.; Lee, } \\
\text { Shara W. Y.; Khaw, M.L.; Chan, Catherine P. L. }\end{array}$ \\
\hline 8 & $\begin{array}{l}\text { Use of masks in public places } \\
\text { in Poland during SARS-Cov-2 } \\
\text { epidemic: a covert } \\
\text { observational study }\end{array}$ & $\begin{array}{l}\text { BMC Public } \\
\text { Health }\end{array}$ & $\begin{array}{l}\text { Ganczak, Maria; Pasek, Oskar; Duda-Duma, Lukasz; } \\
\text { Swistara, Dawid; Korzen, Marcin }\end{array}$ \\
\hline 9 & $\begin{array}{l}\text { Observed Face Mask Use at } \\
\text { Six Universities - United } \\
\text { States, September-November } \\
2020\end{array}$ & $\begin{array}{l}\text { MMWR Morb } \\
\text { Mortal Wkly } \\
\text { Rep }\end{array}$ & $\begin{array}{l}\text { Barrios, Lisa C.; Riggs, Margaret A.; Green, Ridgely Fisk; } \\
\text { Czarnik, Michaila; Nett, Randall J.; Staples, J Erin; Welton, } \\
\text { Michael David; Muilenburg, Jessica Legge; Zullig, Keith } \\
\text { J.; Gibson-Young, Linda; Perkins, Andrea V.; Prins, Cindy; } \\
\text { Lauzardo, Michael; Shapiro, Jerne; Asimellis, George; } \\
\text { Kilgore-Bowling, Genesia; Ortiz-Jurado, Kenny; Gutilla, } \\
\text { Margaret J. }\end{array}$ \\
\hline 10 & $\begin{array}{l}\text { Increasing Facemask } \\
\text { Compliance among Healthcare } \\
\text { Personnel during the COVID- } \\
19 \text { Pandemic }\end{array}$ & $\begin{array}{l}\text { Infect. Control } \\
\text { Hosp. } \\
\text { Epidemiol. }\end{array}$ & $\begin{array}{l}\text { Pellegrino, Anthony; Datta, Rupak; Glenn, Keith; Tuan, } \\
\text { Jessica; Kayani, Jehanzeb; Patel, Kavin; Fisher, Ann; } \\
\text { Linde, Brian; Calo, Lisbeysi; Dembry, Louise Marie }\end{array}$ \\
\hline 11 & $\begin{array}{l}\text { Improving knowledge, } \\
\text { attitudes and practice to } \\
\text { prevent COVID-19 } \\
\text { transmission in Healthcare } \\
\text { workers and the public in } \\
\text { Thailand }\end{array}$ & $\begin{array}{l}\text { BMC Public } \\
\text { Health }\end{array}$ & $\begin{array}{l}\text { Skuntaniyom, Sumawadee; Muntajit, Thanomvong; } \\
\text { Malathum, Kumtorn; Maude, Rapeephan R.; } \\
\text { Jongdeepaisal, Monnaphat; Khuenpetch, Worarat; } \\
\text { Taleangkaphan, Keetakarn; Blacksell, Stuart D.; Pan- } \\
\text { Ngum, Wirichada; Maude, Richard James }\end{array}$ \\
\hline 12 & $\begin{array}{l}\text { An observational study to } \\
\text { identify types of personal } \\
\text { protective equipment breaches }\end{array}$ & J. Hosp. Infect. & Avo, C.; Cawthorne, K.-R.; Walters, J.; Healy, B. \\
\hline
\end{tabular}


It is made available under a CC-BY 4.0 International license .

\begin{tabular}{|c|c|c|c|}
\hline & on inpatient wards & & \\
\hline 13 & $\begin{array}{l}\text { Who is wearing a mask? } \\
\text { Gender-, age-, and location- } \\
\text { related differences during the } \\
\text { COVID-19 pandemic }\end{array}$ & PLOS ONE & $\begin{array}{l}\text { Hart, Meggie Rose; Opielinski, Lauren; Zirgaitis, Gretchen; } \\
\text { Haischer, Michael H.; Beilfuss, Rachel; Uhrich, Toni D.; } \\
\text { Hunter, Sandra K.; Wrucke, David }\end{array}$ \\
\hline 14 & $\begin{array}{l}\text { Prevalence of Face Mask } \\
\text { Wearing in Northern Vermont } \\
\text { in Response to the COVID-19 } \\
\text { Pandemic }\end{array}$ & $\begin{array}{l}\text { Public Health } \\
\text { Rep. }\end{array}$ & Beckage, Brian; Buckley, Thomas E.; Beckage, Maegan E. \\
\hline 15 & $\begin{array}{l}\text { Adherence to social distancing } \\
\text { and wearing of masks within } \\
\text { public transportation during } \\
\text { the COVID-19 pandemic }\end{array}$ & $\begin{array}{l}\text { Transportation } \\
\text { Research } \\
\text { Interdisciplinar } \\
\text { y Perspectives }\end{array}$ & Dzisi, E.K.J.; Dei, O.A. \\
\hline 16 & $\begin{array}{l}\text { Factors associated with } \\
\text { incorrect facemask use among } \\
\text { individuals visiting high-risk } \\
\text { locations during COVID-19 } \\
\text { pandemic }\end{array}$ & $\begin{array}{l}\text { Journal of } \\
\text { Public Health } \\
\text { and } \\
\text { Development }\end{array}$ & $\begin{array}{l}\text { Gunasekaran, S.S.; Gunasekaran, S.S.; Gunasekaran, G.H.; } \\
\text { Zaimi, N.S.I.; Halim, N.A.A.; Halim, F.H.A. }\end{array}$ \\
\hline 17 & $\begin{array}{l}\text { Management and use of filter } \\
\text { masks in the "none-medical" } \\
\text { population during the COVID- } \\
19 \text { period }\end{array}$ & Saf. Sci. & Cumbo, Enzo; Scardina, Giuseppe Alessandro \\
\hline 18 & $\begin{array}{l}\text { Effectiveness of innovation } \\
\text { media for improving physical } \\
\text { distancing compliance during } \\
\text { the COVID-19 pandemic: A } \\
\text { quasi-experiment in Thailand }\end{array}$ & $\begin{array}{l}\text { Int. J. Environ. } \\
\text { Res. Public } \\
\text { Health }\end{array}$ & $\begin{array}{l}\text { Chutiphimon, Hattaya; Thipsunate, Apinya; Cherdchim, } \\
\text { Atigun; Boonyaphak, Bootsarakam; Vithayasirikul, Panat; } \\
\text { Choothong, Patiphan; Vichathai, Swit; Ngamchaliew, } \\
\text { Pitchayanont; Vichitkunakorn, Polathep }\end{array}$ \\
\hline 19 & $\begin{array}{l}\text { The face mask-touching } \\
\text { behavior during the COVID- } \\
19 \text { pandemic: Observational } \\
\text { study of public transportation } \\
\text { users in the greater Paris } \\
\text { region: The French-mask- } \\
\text { touch study. }\end{array}$ & J Transp Health & $\begin{array}{l}\text { Guellich, Aziz; Tella, Emilie; Ariane, Molka; Grodner, } \\
\text { Camille; Nguyen-Chi, Hoai-Nam; Mahe, Emmanuel }\end{array}$ \\
\hline 20 & $\begin{array}{l}\text { An Observational Study of } \\
\text { Mask Guideline Compliance } \\
\text { In An Outpatient OB/GYN } \\
\text { Clinic Population }\end{array}$ & $\begin{array}{l}\text { Eur. J. Obstet. } \\
\text { Gynecol. } \\
\text { Reprod. Biol. }\end{array}$ & Newman, Mark G. \\
\hline 21 & $\begin{array}{l}\text { Installation of pedal-operated } \\
\text { alcohol gel dispensers with } \\
\text { behavioral nudges and changes } \\
\text { in hand hygiene behaviors } \\
\text { during the COVID-19 } \\
\text { pandemic: A hospital-based } \\
\text { quasi-experimental study }\end{array}$ & $\begin{array}{l}\text { J. Public Health } \\
\text { Res. }\end{array}$ & $\begin{array}{l}\text { Wichaidit, Wit; Liabsuetrakul, Tippawan; Naknual, } \\
\text { Sommanas; Kleangkert, Nanta }\end{array}$ \\
\hline 22 & $\begin{array}{l}\text { Mask use among pedestrians } \\
\text { during the COVID-19 } \\
\text { pandemic in Southwest Iran: } \\
\text { an observational study on } \\
10,440 \text { people }\end{array}$ & $\begin{array}{l}\text { BMC Public } \\
\text { Health }\end{array}$ & $\begin{array}{l}\text { Rahimi, Zahra; Cheraghian, Bahman; Shirali, Gholam } \\
\text { Abbas; Araban, Marzieh; Mohammadi, Mohammad Javad }\end{array}$ \\
\hline 23 & $\begin{array}{l}\text { Comparison of Face-Touching } \\
\text { Behaviors before and during } \\
\text { the Coronavirus Disease } 2019 \\
\text { Pandemic }\end{array}$ & $\begin{array}{l}\text { JAMA Netw. } \\
\text { Open }\end{array}$ & $\begin{array}{l}\text { Chen, Yong-Jian; Chen, Jie; Wu, Xiang-Yuan; Li, Xing; } \\
\text { Qin, Gang; Xu, Jian-Liang; Feng, Ding-Yun }\end{array}$ \\
\hline 24 & $\begin{array}{l}\text { Compliance measurement and } \\
\text { observed influencing factors of } \\
\text { hand hygiene based on } \\
\text { COVID-19 guidelines in }\end{array}$ & $\begin{array}{l}\text { Am. J. Infect. } \\
\text { Control }\end{array}$ & Zhou, Qian; Zhang, Xinping; Lai, Xiaoquan; Tan, Li \\
\hline
\end{tabular}


medRxiv preprint doi: https://doi.org/10.1101/2021.12.22.21268226; this version posted December 23, 2021. The copyright holder for this preprint (which was not certified by peer review) is the author/funder, who has granted medRxiv a license to display the preprint in perpetuity.

It is made available under a CC-BY 4.0 International license .

\begin{tabular}{|c|c|c|c|}
\hline & China & & \\
\hline 25 & $\begin{array}{l}\text { Adherence to personal } \\
\text { protective equipment use } \\
\text { among Healthcare workers } \\
\text { caring for confirmed COVID- } \\
19 \text { and alleged non-COVID- } \\
19 \text { patients }\end{array}$ & $\begin{array}{l}\text { Antimicrob. } \\
\text { Resist. Infect. } \\
\text { Control }\end{array}$ & Neuwirth, Meike M.; Mattner, Frauke; Otchwemah, Robin \\
\hline 26 & $\begin{array}{l}\text { COVID-19 and face mask use: } \\
\text { A st. kitts case study }\end{array}$ & $\begin{array}{l}\text { Open Access } \\
\text { Maced. J. Med. } \\
\text { Sci. }\end{array}$ & $\begin{array}{l}\text { Kungurova, Yulia; Brewster, Evelyn; Mera, Ritha; Ali, } \\
\text { Khalil; Fakoya, Adegbenro O.J. }\end{array}$ \\
\hline 27 & $\begin{array}{l}\text { Facemask wearing to prevent } \\
\text { COVID-19 transmission and } \\
\text { associated factors among taxi } \\
\text { drivers in Dessie City and } \\
\text { Kombolcha Town, Ethiopia }\end{array}$ & PLoS ONE & $\begin{array}{l}\text { Natnael, Tarikuwa; Berihun, Gete; Abebe, Masresha; } \\
\text { Adane, Metadel; Alemnew, Yeshiwork; Andualem, } \\
\text { Atsedemariam; Ademe, Sewunet; Tegegne, Belachew }\end{array}$ \\
\hline 28 & $\begin{array}{l}\text { Face Covering Adherence In } \\
\text { An Outpatient Ophthalmology } \\
\text { Clinic During COVID-19 }\end{array}$ & $\begin{array}{l}\text { Ophthalmic } \\
\text { Epidemiol. }\end{array}$ & Parikh, Ankur; Kondapalli, Srinivas \\
\hline 29 & $\begin{array}{l}\text { Behavior in the use of face } \\
\text { masks in the context of } \\
\text { COVID-19 }\end{array}$ & $\begin{array}{l}\text { Public Health } \\
\text { Nurs. }\end{array}$ & Kellerer, Jan D.; Rohringer, Matthias; Deufert, Daniela \\
\hline 30 & $\begin{array}{l}\text { Community-based } \\
\text { observational assessment of } \\
\text { compliance by the public with } \\
\text { COVID-19 preventive } \\
\text { measures in the south of Saudi } \\
\text { Arabia. }\end{array}$ & Saudi J Biol Sci & $\begin{array}{l}\text { Gosadi, Ibrahim M; Daghriri, Khaled A; Shugairi, Ahmad } \\
\text { A; Alharbi, Ali H; Suwaydi, Abdullatif Z; Alharbi, } \\
\text { Mohammed A; Majrashi, Ali A; Sumaily, Ibraheim A }\end{array}$ \\
\hline 31 & $\begin{array}{l}\text { Public Compliance with Face } \\
\text { Mask Use in Honolulu and } \\
\text { Regional Variation }\end{array}$ & $\begin{array}{l}\text { Hawaii J Health } \\
\text { Soc Welf }\end{array}$ & $\begin{array}{l}\text { Tamamoto, Kasey A.; Rousslang, Nikki D.; Ahn, Hyeong } \\
\text { Jun; Better, Heidi E.; Hong, Robert A. }\end{array}$ \\
\hline 32 & $\begin{array}{l}\text { Adherence of the General } \\
\text { Public to Self-protection } \\
\text { Guidelines During the } \\
\text { COVID-19 Pandemic }\end{array}$ & $\begin{array}{l}\text { Disaster Med } \\
\text { Public Health } \\
\text { Prep }\end{array}$ & $\begin{array}{l}\text { Jabbari, Parnian; Taraghikhah, Nazanin; Jabbari, Forouq; } \\
\text { Ebrahimi, Saied; Rezaei, Nima }\end{array}$ \\
\hline 33 & $\begin{array}{l}\text { How do the general population } \\
\text { behave with facemasks to } \\
\text { prevent COVID-19 in the } \\
\text { community? A multi-site } \\
\text { observational study }\end{array}$ & $\begin{array}{l}\text { Antimicrob. } \\
\text { Resist. Infect. } \\
\text { Control }\end{array}$ & $\begin{array}{l}\text { Haudebourg, Thomas; Blanckaert, Karine; Deschanvres, } \\
\text { Colin; Boutoille, David; Peiffer-Smadja, Nathan; Lucet, } \\
\text { Jean-Christophe; Birgand, Gabriel }\end{array}$ \\
\hline 34 & $\begin{array}{l}\text { First report on smoking and } \\
\text { infection control behaviours at } \\
\text { outdoor hotspots during the } \\
\text { COVID-19 pandemic: An } \\
\text { unobtrusive observational } \\
\text { study }\end{array}$ & $\begin{array}{l}\text { Int. J. Environ. } \\
\text { Res. Public } \\
\text { Health }\end{array}$ & $\begin{array}{l}\text { Sun, Yuying; Lam, Tai Hing; Chen, Jianjiu; Zhang, Xiaoyu; } \\
\text { Ho, Sai Yin; Cheung, Yee Tak Derek; Wang, Man Ping; } \\
\text { Wu, Yongda; Li, William H. C. }\end{array}$ \\
\hline 35 & $\begin{array}{l}\text { Youth Mask-Wearing and } \\
\text { Social-Distancing Behavior at } \\
\text { In-Person High School } \\
\text { Graduations During the } \\
\text { COVID-19 Pandemic }\end{array}$ & $\begin{array}{l}\text { J. Adolesc. } \\
\text { Health }\end{array}$ & $\begin{array}{l}\text { Mueller, Anna S.; Beardall, Katherine A.; Millar, Krystina; } \\
\text { Watkins, James T.; Diefendorf, Sarah; Abrutyn, Seth; } \\
\text { O'Reilly, Lauren; Steinberg, Hillary }\end{array}$ \\
\hline 36 & $\begin{array}{l}\text { Towards Enforcing Social } \\
\text { Distancing Regulations with } \\
\text { Occlusion-Aware Crowd } \\
\text { Detection }\end{array}$ & $\begin{array}{l}\text { 16th IEEE } \\
\text { International } \\
\text { Conference on } \\
\text { Control, } \\
\text { Automation, } \\
\text { Robotics and } \\
\text { Vision, } \\
\text { ICARCV } 2020\end{array}$ & Cong, C.; Yang, Z.; Song, Y.; Pagnucco, M. \\
\hline
\end{tabular}


medRxiv preprint doi: https://doi.org/10.1101/2021.12.22.21268226; this version posted December 23, 2021. The copyright holder for this preprint (which was not certified by peer review) is the author/funder, who has granted medRxiv a license to display the preprint in perpetuity.

It is made available under a CC-BY 4.0 International license .

\begin{tabular}{|c|c|c|c|}
\hline 37 & $\begin{array}{l}\text { Obstetric Healthcare workers' } \\
\text { adherence to hand hygiene } \\
\text { recommendations during the } \\
\text { COVID-19 pandemic: } \\
\text { Observations and social- } \\
\text { cognitive determinants. }\end{array}$ & $\begin{array}{l}\text { Applied } \\
\text { Psychology: } \\
\text { Health and } \\
\text { Well-Being }\end{array}$ & Derksen, Christina; Keller, Franziska M; Lippke, Sonia \\
\hline 38 & $\begin{array}{l}\text { Implications of a US study on } \\
\text { infection prevention and } \\
\text { control in community settings } \\
\text { in the UK }\end{array}$ & $\begin{array}{l}\text { British Journal } \\
\text { of Community } \\
\text { Nursing }\end{array}$ & Dowding, D.; McDonald, M.V.; Shang, J. \\
\hline 39 & $\begin{array}{l}\text { Achieving Perfect Hand } \\
\text { Washing: an Audit Cycle with } \\
\text { Surgical Internees }\end{array}$ & $\begin{array}{l}\text { Indian Journal } \\
\text { of Surgery }\end{array}$ & Mukherjee, R.; Roy, P.; Parik, M. \\
\hline 40 & $\begin{array}{l}\text { Observational study of } \\
\text { compliance with infection } \\
\text { control practices among } \\
\text { Healthcare workers in } \\
\text { subsidized and private } \\
\text { residential care homes }\end{array}$ & $\begin{array}{l}\text { BMC Infectious } \\
\text { Diseases }\end{array}$ & Au, J.K.L.; Suen, L.K.P.; Lam, S.C. \\
\hline 41 & $\begin{array}{l}\text { Who Wears a Mask? Gender } \\
\text { Differences in Risk } \\
\text { Behaviours in the COVID-19 } \\
\text { Early Days in Taiwan }\end{array}$ & $\begin{array}{l}\text { Economics } \\
\text { Bulletin }\end{array}$ & Chuang, Y.; Chung-En Liu, J. \\
\hline 42 & $\begin{array}{l}\text { The impact of COVID-19 } \\
\text { pandemic on hand hygiene } \\
\text { performance in hospitals }\end{array}$ & $\begin{array}{l}\text { journal of } \\
\text { infection } \\
\text { control }\end{array}$ & Moore LD, Robbins G, Quinn J, Arbogast JW \\
\hline 43 & $\begin{array}{l}\text { The impact of coronavirus } \\
\text { disease } 2019 \text { (COVID-19) on } \\
\text { provider use of electronic hand } \\
\text { hygiene monitoring } \\
\text { technology }\end{array}$ & $\begin{array}{l}\text { Infect Control } \\
\text { Hosp } \\
\text { Epidemiol. }\end{array}$ & Hess OCR, Armstrong-Novak JD, Doll M, et al \\
\hline 44 & $\begin{array}{l}\text { Surveillance of the infection } \\
\text { prevention and control } \\
\text { practices of healthcare workers } \\
\text { by an infection control } \\
\text { surveillance-working group } \\
\text { and a team of infection control } \\
\text { coordinators during the } \\
\text { COVID-19 pandemic }\end{array}$ & $\begin{array}{l}\text { J Infect Public } \\
\text { Health }\end{array}$ & Choi UY, Kwon YM, Kang HJ, et al. \\
\hline 45 & $\begin{array}{l}\text { Rigorous Hand Hygiene } \\
\text { Practices Among Health Care } \\
\text { Workers Reduce Hospital- } \\
\text { Associated Infections During } \\
\text { the COVID-19 Pandemic. }\end{array}$ & $\begin{array}{l}\text { J Prim Care } \\
\text { Community } \\
\text { Health. }\end{array}$ & Roshan R, Feroz AS, Rafique Z, Virani \\
\hline 46 & $\begin{array}{l}\text { Use of Proper Personal } \\
\text { Protective Measures among } \\
\text { Parents of Children Attending } \\
\text { Outpatient Department - An } \\
\text { Observational Study }\end{array}$ & Indian J Pediatr & Clinton M, Sankar J, Ramesh V, Madhusudan M. \\
\hline 47 & $\begin{array}{l}\text { Observation of Hand Hygiene } \\
\text { Practices in Home Health } \\
\text { Care. }\end{array}$ & $\begin{array}{l}\text { J Am Med Dir } \\
\text { Assoc. }\end{array}$ & McDonald MV, Brickner C, Russell D, et al. \\
\hline 48 & $\begin{array}{l}\text { Observing COVID-19 related } \\
\text { behaviours in a high visitor } \\
\text { use area of Arches National } \\
\text { Park }\end{array}$ & PLoS One. & Miller ZD, Freimund W, Dalenberg D, Vega M. \\
\hline
\end{tabular}


medRxiv preprint doi: https://doi.org/10.1101/2021.12.22.21268226; this version posted December 23, 2021. The copyright holder for this preprint (which was not certified by peer review) is the author/funder, who has granted medRxiv a license to display the preprint in perpetuity.

It is made available under a CC-BY 4.0 International license .

Table 5: NON-COVID-19 papers included in synthesis

\begin{tabular}{|c|c|c|c|}
\hline Study & Title & Journal & Authors \\
\hline 1 & $\begin{array}{l}\text { Mentor's hand hygiene practices } \\
\text { influence student's hand hygiene } \\
\text { rates. }\end{array}$ & Am J Infect Control & $\begin{array}{l}\text { Snow, Michelle; White, George L Jr; } \\
\text { Alder, Stephen C; Stanford, Joseph } \\
\text { B }\end{array}$ \\
\hline 2 & $\begin{array}{l}\text { Handwashing patterns in two } \\
\text { dermatology clinics. }\end{array}$ & Dermatology & $\begin{array}{l}\text { Cohen, H A; Kitai, E; Levy, I; Ben- } \\
\text { Amitai, D }\end{array}$ \\
\hline 3 & $\begin{array}{l}\text { Infection control among } \\
\text { professional tattooists in } \\
\text { Minneapolis and St. Paul, MN. }\end{array}$ & Public Health Rep & $\begin{array}{l}\text { Raymond, M J; Pirie, P L; Halcon, L } \\
\text { L }\end{array}$ \\
\hline 4 & $\begin{array}{l}\text { Should self-assessment methods be } \\
\text { used to measure compliance with } \\
\text { handwashing recommendations? A } \\
\text { study carried out in a French } \\
\text { university hospital. }\end{array}$ & Am J Infect Control & $\begin{array}{l}\text { Moret, Leila; Tequi, Brigitte; } \\
\text { Lombrail, Pierre }\end{array}$ \\
\hline 5 & $\begin{array}{l}\text { A comparison of observed and self- } \\
\text { reported compliance with universal } \\
\text { precautions among emergency } \\
\text { department personnel at a } \\
\text { Minnesota public teaching hospital: } \\
\text { Implications for assessing infection } \\
\text { control programs }\end{array}$ & ANN. EMERG. MED. & Henry, K.; Campbell, S.; Maki, M. \\
\hline 6 & $\begin{array}{l}\text { Hand hygiene before donning } \\
\text { nonsterile gloves: Healthcare } \\
\text { workers' beliefs and practices. }\end{array}$ & Am J Infect Control & $\begin{array}{l}\text { Baloh, Jure; Thom, Kerri A; } \\
\text { Perencevich, Eli; Rock, Clare; } \\
\text { Robinson, Gwen; Ward, Melissa; } \\
\text { Herwaldt, Loreen; Reisinger, } \\
\text { Heather Schacht }\end{array}$ \\
\hline 7 & $\begin{array}{l}\text { Is evidence guiding practice? } \\
\text { Reported versus observed adherence } \\
\text { to contact precautions: a pilot study. }\end{array}$ & Am J Infect Control & Jessee, Mary Ann; Mion, Lorraine C \\
\hline 8 & $\begin{array}{l}\text { Hand Hygiene Compliance Study at } \\
\text { a Large Central Hospital in } \\
\text { Vietnam. }\end{array}$ & Int J Environ Res Public Health & $\begin{array}{l}\text { Le, Cam Dung; Lehman, Erik B; } \\
\text { Nguyen, Thanh Huy; Craig, } \\
\text { Timothy J }\end{array}$ \\
\hline 9 & $\begin{array}{l}\text { Do wearable alcohol-based handrub } \\
\text { dispensers increase hand hygiene } \\
\text { compliance? - a mixed-methods } \\
\text { study. }\end{array}$ & Antimicrob. resist. infect. control & $\begin{array}{l}\text { Keller, Jonas; Wolfensberger, Aline; } \\
\text { Clack, Lauren; Kuster, Stefan P; } \\
\text { Dunic, Mesida; Eis, Doris; } \\
\text { Flammer, Yvonne; Keller, Dagmar I; } \\
\text { Sax, Hugo }\end{array}$ \\
\hline 10 & $\begin{array}{l}\text { Beyond entry and exit: Hand } \\
\text { hygiene at the bedside. }\end{array}$ & Am J Infect Control & $\begin{array}{l}\text { Woodard, Jennifer A; Leekha, } \\
\text { Surbhi; Jackson, Sarah S; Thom, } \\
\text { Kerri A }\end{array}$ \\
\hline
\end{tabular}


medRxiv preprint doi: https://doi.org/10.1101/2021.12.22.21268226; this version posted December 23, 2021. The copyright holder for this preprint (which was not certified by peer review) is the author/funder, who has granted medRxiv a license to display the preprint in perpetuity.

It is made available under a CC-BY 4.0 International license .

\begin{tabular}{|c|c|c|c|}
\hline 11 & $\begin{array}{l}\text { Comparison of patient and } \\
\text { healthcare professional perceptions } \\
\text { of hand hygiene practices with the } \\
\text { monthly internal audit at a tertiary } \\
\text { medical center, Illinois } 2010\end{array}$ & Am. J. Infect. Control & Soyemi, Caroline \\
\hline 12 & $\begin{array}{l}\text { Medical students and hospital hand } \\
\text { hygiene - What do they know, and } \\
\text { what do they do? }\end{array}$ & Surg. Infect. & $\begin{array}{l}\text { Alemayehu, Hanna; Ho, Vanessa P.; } \\
\text { Leviter, Julie I.; Drusin, Lewis M.; } \\
\text { Barie, Philip S. }\end{array}$ \\
\hline 13 & $\begin{array}{l}\text { Effectiveness of a hand hygiene } \\
\text { improvement program in doctors: } \\
\text { Active monitoring and real-time } \\
\text { feedback }\end{array}$ & Antimicrob. Resist. Infect. Control & $\begin{array}{l}\text { Kim, S.R.; Cho, M.H.; Kim, W.J.; } \\
\text { Song, J.Y.; Cheong, H.J. }\end{array}$ \\
\hline 14 & $\begin{array}{l}\text { Mind the mind: Results of a hand- } \\
\text { hygiene research in a state-of-the-art } \\
\text { cancer hospital }\end{array}$ & Indian J. Med. Microbiol. & $\begin{array}{l}\text { Dalen, R.; Gombert, K.; } \\
\text { Bhattacharya, S.; Datta, S. }\end{array}$ \\
\hline 15 & $\begin{array}{l}\text { A quasi-experimental study to } \\
\text { determine the effects of a } \\
\text { multifaceted educational } \\
\text { intervention on hand hygiene } \\
\text { compliance in a radiography unit }\end{array}$ & Antimicrob. Resist. Infect. Control & $\begin{array}{l}\text { O'Donoghue, Margaret; Ng, Suk- } \\
\text { Hing; Suen, Lorna K.P.; Boost, } \\
\text { Maureen }\end{array}$ \\
\hline 16 & $\begin{array}{l}\text { Promoting Handwashing Behavior: } \\
\text { The Effects of Large-scale } \\
\text { Community and School-level } \\
\text { Interventions }\end{array}$ & Health Econ. & $\begin{array}{l}\text { Galiani, Sebastian; Gertler, Paul; } \\
\text { Ajzenman, Nicolas; Orsola-Vidal, } \\
\text { Alexandra }\end{array}$ \\
\hline 17 & $\begin{array}{l}\text { Knowledge and practice of infection } \\
\text { control-in the NDM1 era }\end{array}$ & Antimicrob. Resist. Infect. Control & $\begin{array}{l}\text { Lakshmi, V.; Ghafur, A.; } \\
\text { Mageshkumar, K.; Karupusamy, C. }\end{array}$ \\
\hline 18 & $\begin{array}{l}\text { Flawed self-assessment in hand } \\
\text { hygiene: A major contributor to } \\
\text { infections in clinical practice? }\end{array}$ & Journal of Clinical Nursing & $\begin{array}{l}\text { Kelcikova, Simona; Mazuchova, } \\
\text { Lucia; Bielena, Lubica; Filova, } \\
\text { Lenka }\end{array}$ \\
\hline
\end{tabular}


medRxiv preprint doi: https://doi.org/10.1101/2021.12.22.21268226; this version posted December 23, 2021. The copyright holder for this preprint (which was not certified by peer review) is the author/funder, who has granted medRxiv a license to display the preprint in perpetuity. It is made available under a CC-BY 4.0 International license .

Table 7: NIH quality assessment checklist

Criteria Yes No Other

$(\mathrm{CD}$, NR, $\mathrm{NA})^{*}$

1. Was the research question or objective in this paper clearly stated?

2. Was the study population clearly specified and defined?

3. Was the participation rate of eligible persons at least $50 \%$ ?

4. Were all the subjects selected or recruited from the same or similar populations (including the same time period)? Were inclusion and exclusion criteria for being in the study

prespecified and applied uniformly to all participants?

5. Was a sample size justification, power description, or variance and effect estimates provided?

6. For the analyses in this paper, were the exposure(s) of interest measured prior to the outcome(s) being measured? 
medRxiv preprint doi: https://doi.org/10.1101/2021.12.22.21268226; this version posted December 23, 2021. The copyright holder for this preprint (which was not certified by peer review) is the author/funder, who has granted medRxiv a license to display the preprint in perpetuity.

It is made available under a CC-BY 4.0 International license .

Criteria

Yes No Other

$(\mathrm{CD}$,

NR,

$\mathrm{NA})^{*}$

7. Was the timeframe sufficient so that one could reasonably expect to see an association between exposure and outcome if it existed?

8. For exposures that can vary in amount or level, did the study examine different levels of the exposure as related to the outcome (e.g., categories of exposure, or exposure measured as continuous variable)?

9. Were the exposure measures (independent variables) clearly defined, valid, reliable, and implemented consistently across all study participants?

10. Was the exposure(s) assessed more than once over time?

11. Were the outcome measures (dependent variables) clearly defined, valid, reliable, and implemented consistently across all study participants?

12. Were the outcome assessors blinded to the exposure status of participants? 
medRxiv preprint doi: https://doi.org/10.1101/2021.12.22.21268226; this version posted December 23, 2021. The copyright holder for this preprint (which was not certified by peer review) is the author/funder, who has granted medRxiv a license to display the preprint in perpetuity. It is made available under a CC-BY 4.0 International license .

Criteria

Yes No Other

$(\mathrm{CD}$,

$\mathrm{NR}$,

$\mathrm{NA})^{*}$

13. Was loss to follow-up after baseline $20 \%$ or less?

14. Were key potential confounding variables measured and adjusted statistically for their impact on the relationship between exposure(s) and outcome(s)? 